\title{
Uma ferramenta de importação de documentos HTML para um ambiente de ensino
}

\author{
Renato Ribeiro Haber
}

\author{
Orientação: \\ Prof ${ }^{a}$. Dr ${ }^{\mathrm{a}}$. Maria das Graças Volpe Nunes
}

Dissertação apresentada ao Instituto de Ciências Matemáticas e de Computação - USP, como parte dos requisitos para obtenção do título de Mestre em Ciências -

Area de Ciências de Computação e Matemática Computacional. 
'Eis que o lavrador espera o precioso fruto da terra, aguardando-o com paciência, até que receba a chuva temporã. Sede vós também pacientes, fortalecei os vossos corafões, porque jä a vinda do Senbor está próxima."

Tiago 5:7-8

"O Homem está mais próximo de descobrir os segredos da mais distante das galáxias, do que os do seu coraf̧ão."

Dedico este trabalho à memória de meu pai. 


\section{Agradecimentos}

À Deus, por me conceder saúde, por jluminar meu caminho e por me abençoar na realização de todos os meus deveres.

Meu carinho e gratidão à Maria das Graças Volpe Nunes, minha orientadora. Seus elogios, suas críticas, sugestōes e contribuições me ajudaram muito durante o meu mestrado.

A minha mãe, Valdinéris Lúcia Ribeiro Haber, minha amiga, companheira e guerreira de oração. Obrigado pela Fé, apoio, amor e coragem que me transmitiu nos diversos momentos de dificuldade.

Meus sinceros agradecimentos a todos colegas da USP. Em especial à: Adrianinha, Alexandre, Anja, Boni, Daniel Pires, Elderclai, Fábio, Gláucia, João, Laércio, Luciano, Márcio "Taboca", Marcos Kutova, Maria Alice, Maria Helena, Ricardo Hasegawa, Roger, Rudinei e Silvio.

Às secretárias da Pós-Graduação, Andressa, Beth, Laura e Marilia, pela amizade e presteza com que sempre me atenderam.

Ao pessoal de casa: Cidinha, Dedéia, Di, Elaine, Marquinho e Omar. Obrigado pelas noites de "gargalhadas" e pelo companheirismo.

Ao $\mathrm{CNPq}$, pelo apoio financeiro concedido.

À Tânia, o meu agradecimento especial, pela sua Fé, pela sua amizade, pelo seu amor, pela sua preocupação e pelos seus sorrisos. 


\section{Sumário}

Lista de figuras e tabelas ............................................................................. vii

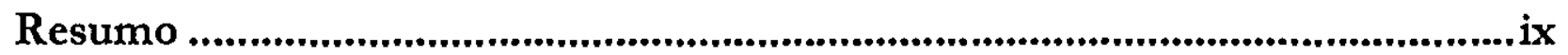

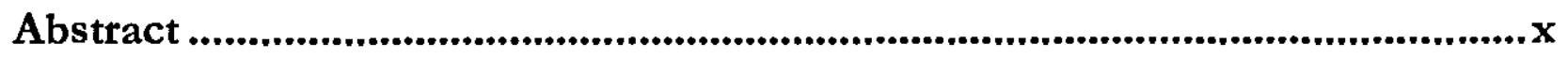

1. Inttodução ............................................................................................................... 1

1.1 - Considerações iniciais .................................................................................................................

1.2 - Motivação e objetivos ................................................................................................................

1.3 - Organização..........................................................................................................................................

2. A informática como ferramenta de apoio à Educação ......................................6

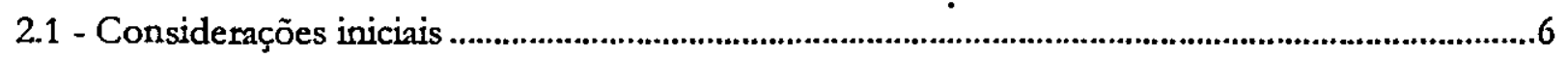

2.2 - Recursos empregados no suporte ao ensino e aprendizado ........................................................

2.2 .1 - Simulações..........................................................................................................................

2.2.2 - Sistemas de resolução de problemas ..........................................................................................

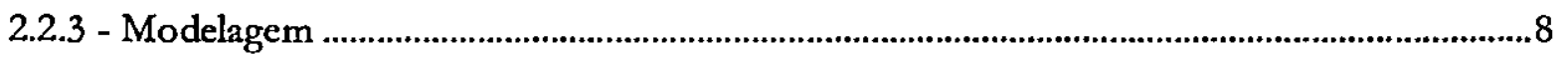

2.2 .4 - Jogos educativos..................................................................................................................

2.2 .5 - Hipertexto ................................................................................................................

2.2.6 - Multimídia e Hipermídia ................................................................................................... 10

2.3 - Mecanismos para o equilibrio entre o controle do aprendiz e do sistema................................. 10

2.3.1 - Roteiros como forma de controle e orientação................................................................... 11

2.3.2 - Nós de contexto........................................................................................................... 12

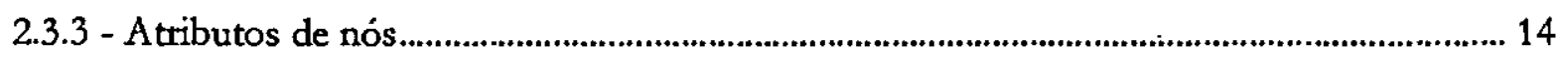

2.3.4 - Hipermídia adaptativa .................................................................................................... 15

2.4 - Métodos para modelagem de aplicações hipermídia ................................................................. 16

2.5 - Considerações finais do capítulo .............................................................................................. 18

3. Ambientes de autoria, estruturação e distribuição de material didático ...... 20

3.1 - Considerações iniciais ................................................................................................... 20

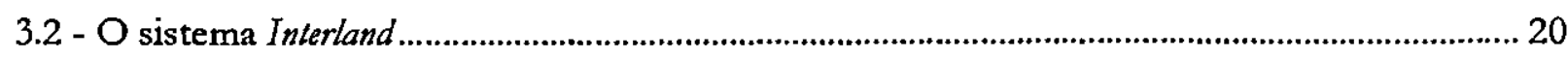

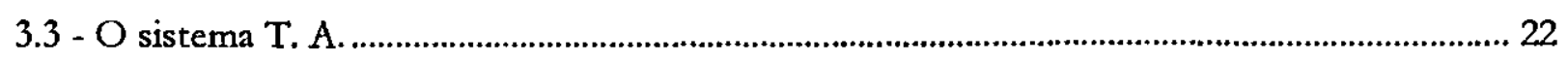




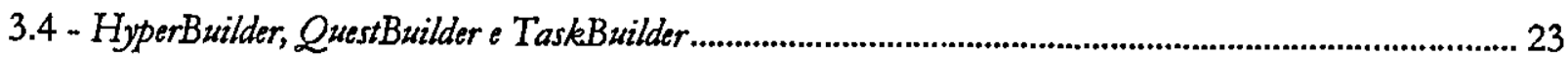

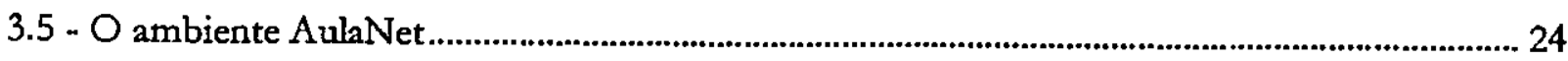

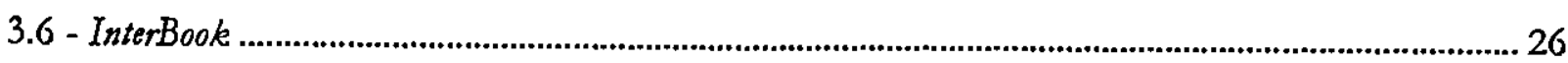

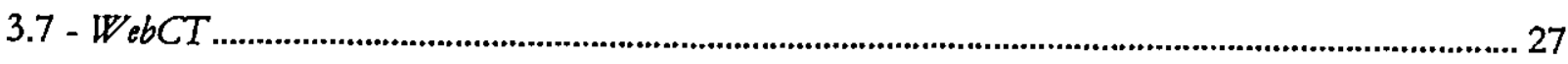

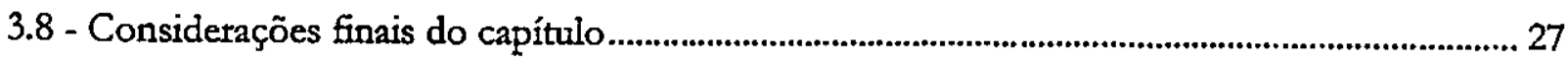

4. Estruturação e intercâmbio de documentos hipermídia............................... 29

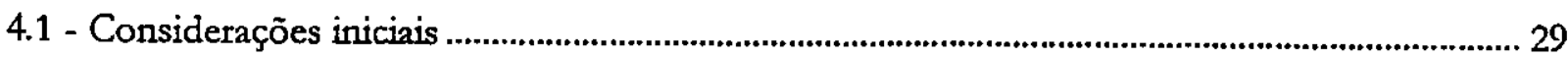

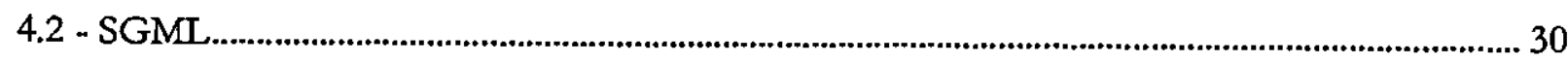

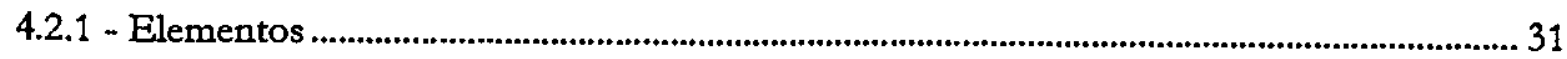

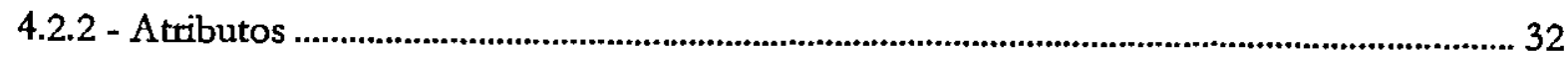

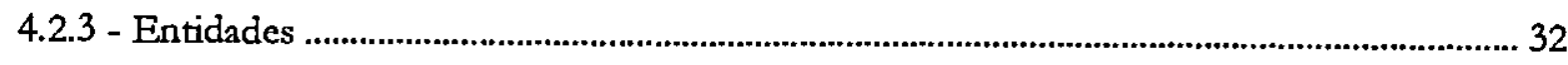

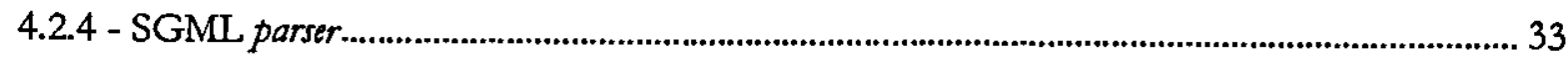

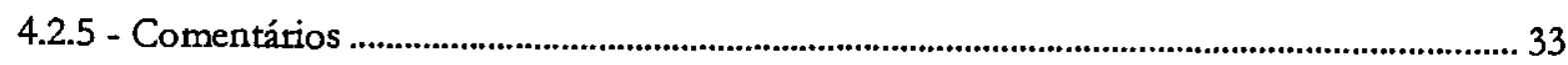

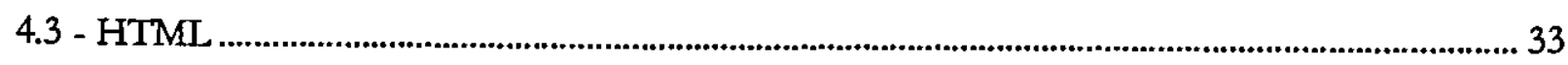

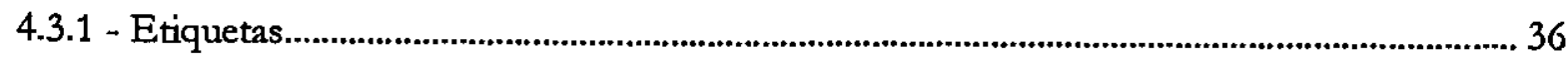

4.3.2 - Estabelecimento de relacionamentos............................................................................... 36

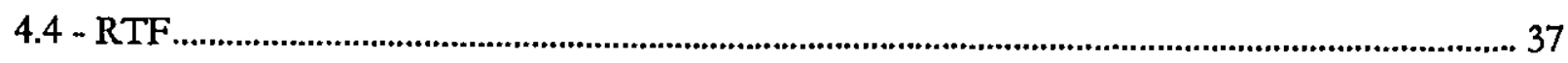

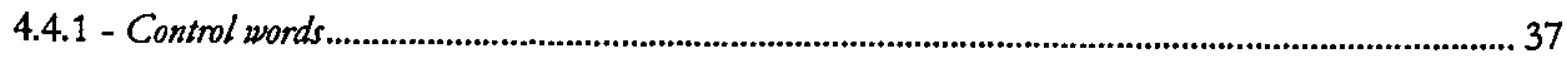

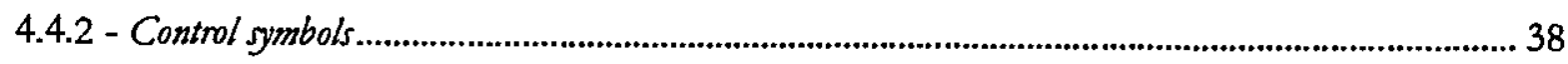

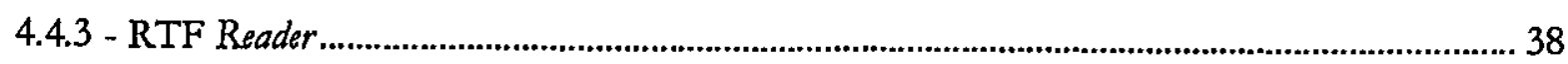

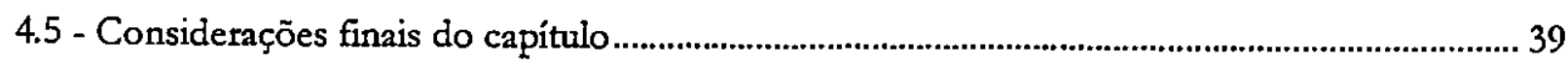

5. SASHE - Sistema de Autoria e Suporte Hipermídia para Ensino..................41

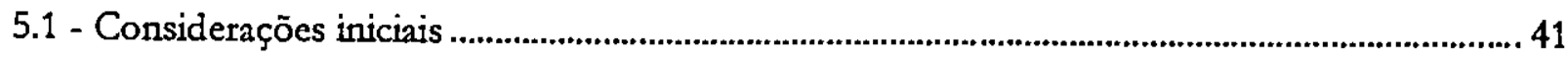

5.2 - MCA - Modelo de Contextos Aninhados................................................................................. 42

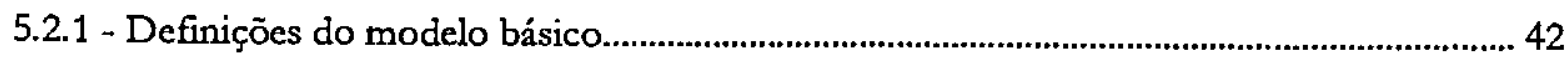

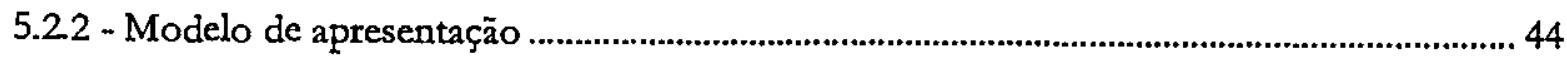

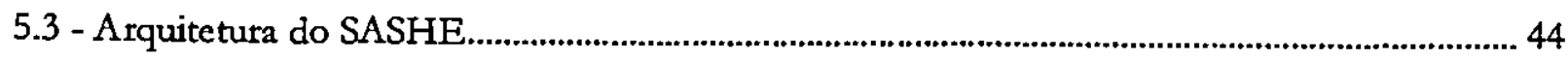

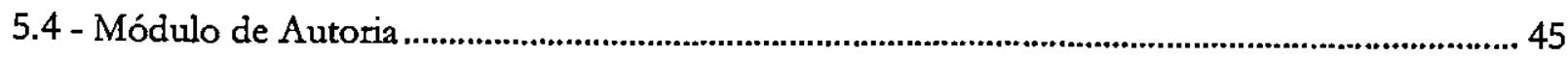

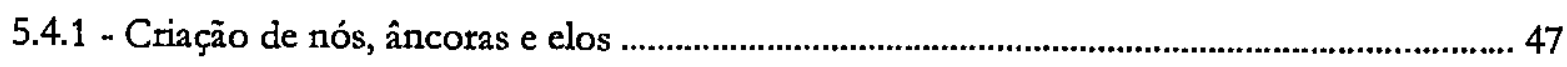

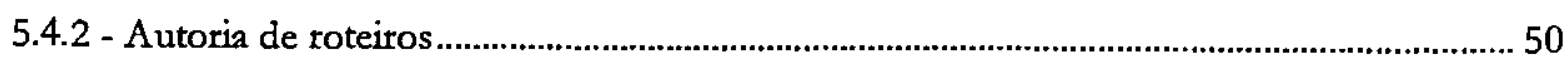

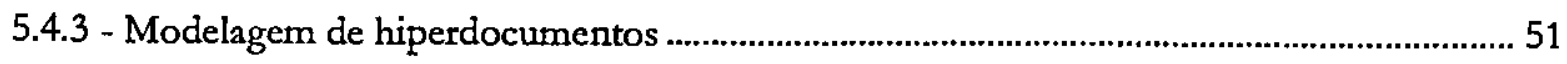

5.4.4 - Importação e adaptaçäo de documentos HTML ............................................................. 52 


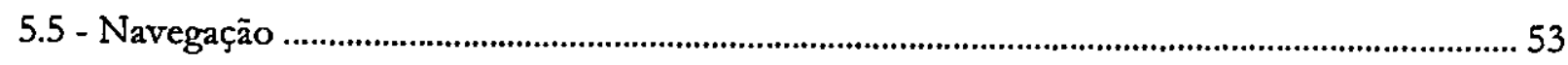

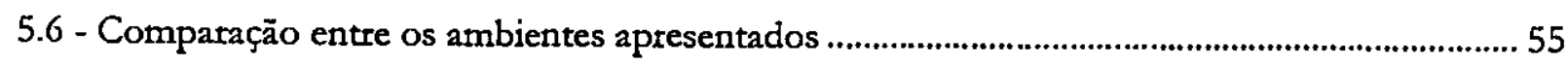

5.7 - Considerações finais do capitulo .........................................................................................5

6. Html2Hip - Uma ferramenta de importação de documentos HTML.......... 60

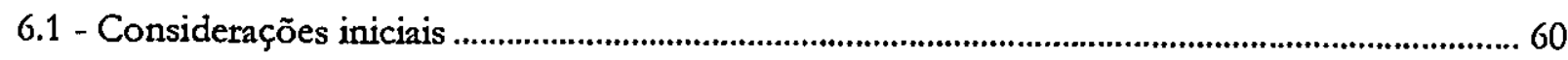

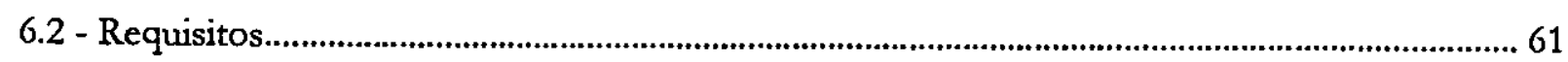

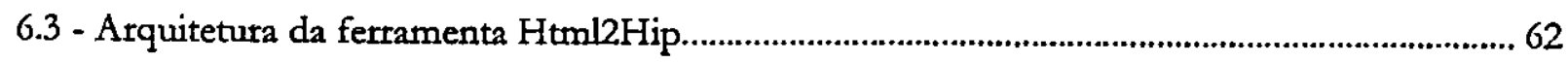

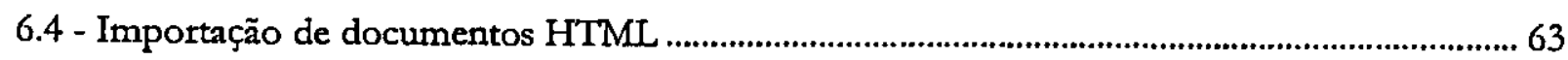

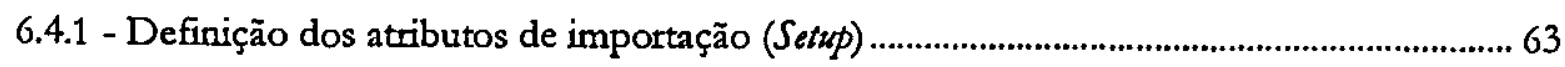

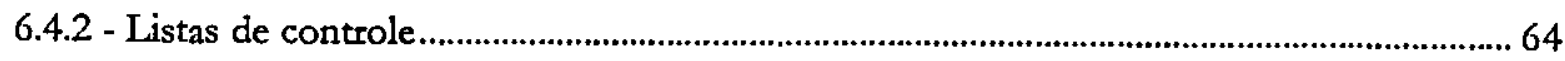

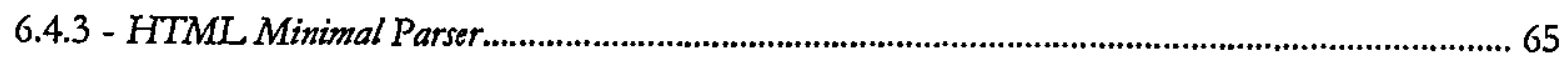

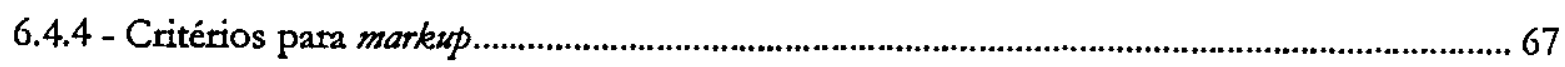

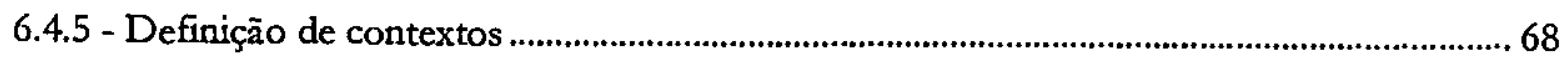

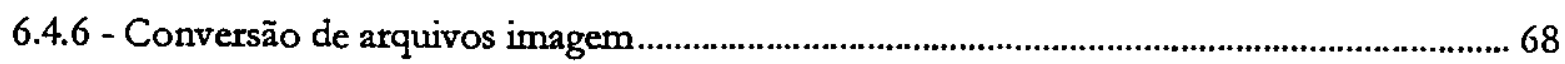

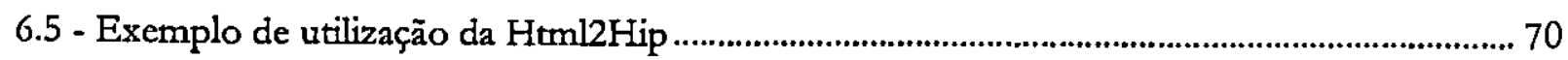

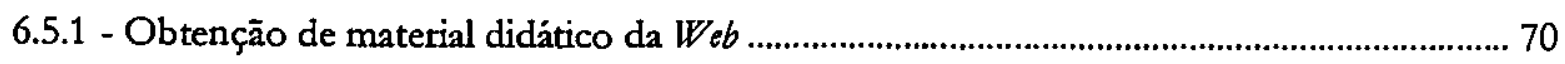

6.5.2 - Preparação do ambiente de importação ........................................................................ 72

6.5.3 - Definição das propriedades de importação ...................................................................... 73

6.5.4 - Geração do protótipo de hiperdocumento ...................................................................... 75

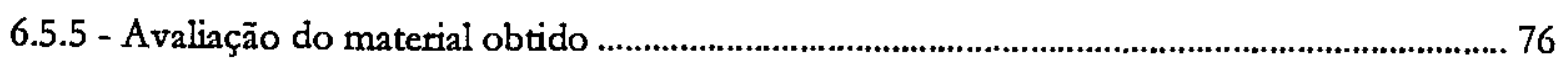

6.5.6 - Inserção de nós de informação do tipo imagem .............................................................. 77

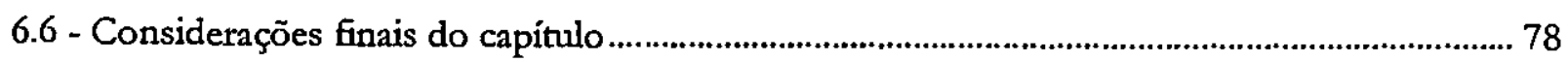

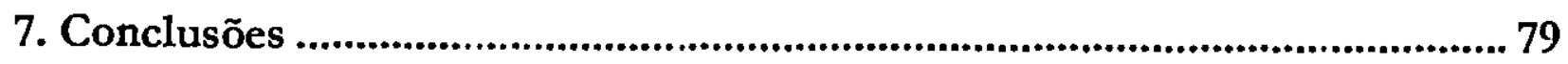

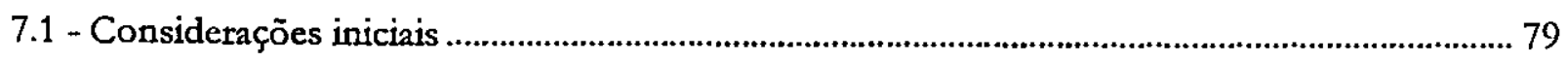

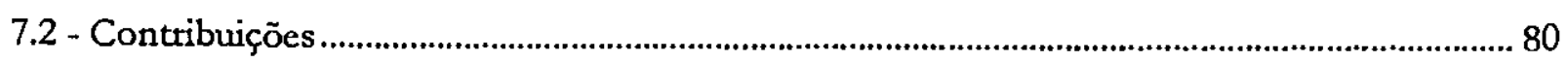

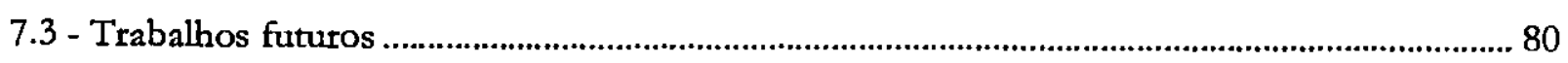

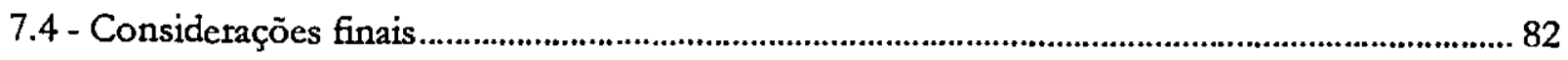

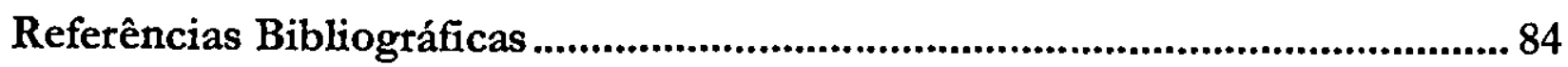

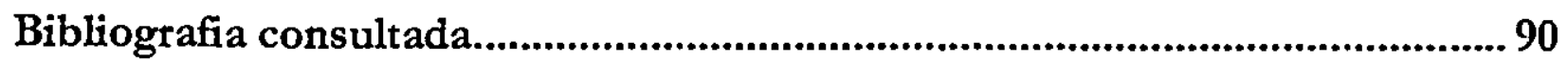




\section{Lista de figuras e tabelas}

Figura 2.1 - Hiperdocumento simples com 5 nós e 7 elos (Nielsen, 1990)............................................9

Figura 2.2 - Representação gráfica de um hiperdocumento (Santos, 1997) ..........................................13

Tabela 2.1 - Descrição de um possível roteiro …................................................................................... 13

Figura 3.1 - Sistema Intetland (interface do aptendiz) ....................................................................... 21

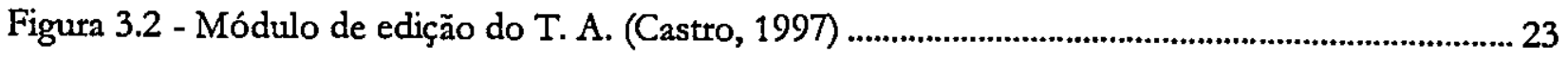

Figura 3.3 - Interface da ferramenta HyperBuilder ................................................................................ 24

Figura 3.4 - Interface do aprendiz no AulaNet (AulaNet, 1999) ............................................................ 25

Figura 3.5 - Livro-texto criado com o InterBook (Brusilovsky et al., 1996) .......................................... 26

Figuta 4.1 - Anatomia de um elemento SGML (Herwijnen, 1994) ..................................................... 31

Figura 4.2 - Estrutura hierárquica dos capítulos dessa dissertação......................................................... 32

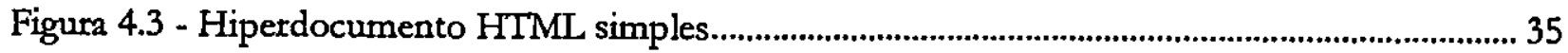

Figura 4.4 - Visualização do código HTML da Figuta 4.3 …............................................................. 35

Figura 5.1 - Hierarquia de classes do MCA (Soares et al., 1994) ........................................................42

Figura 5.2 - Arquitetura geral do SASHE versão 2.0............................................................................ 45

Figura 5.3 - Interface do Browser Gráfico (Nunes et al., 1997) ............................................................. 46

Figura 5.4 - Exemplo de um hiperdocumento estruturado ...................................................................4 47

Figura 5.5 - Interface para criação de nós do tipo contexto...................................................................4 47

Figura 5.6 - Interface para criação de nós de informação (terminais) …................................................4 48

Figura 5.7 - Âncora sendo criada em um nó de informação do tipo texto .............................................48

Figuta 5.8 - Interface de criação/edição de elos...................................................................................... 49

Figura 5.9 - Interface para a definição/seleção do grau de liberdade de navegação............................. 50

Figura 5.10 - Interface para a definição de toteiros ................................................................................. 51

Figuta 5.11 - Módulo de navegação (interface do aprendiz) ................................................................. 53

Figura 5.12 - Correspondências entre atributos para estratégias tutoriais embutidas nos botões "Está

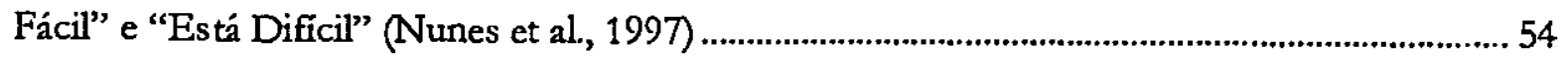

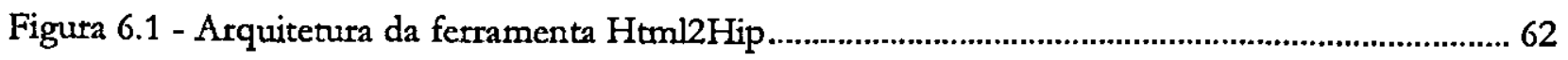

Figura 6.2 - Hierarquia de classes um documento criado com a HTML2HIP.......................................6 64 


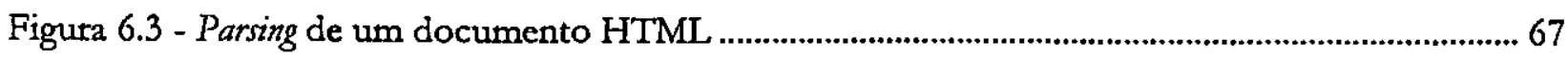

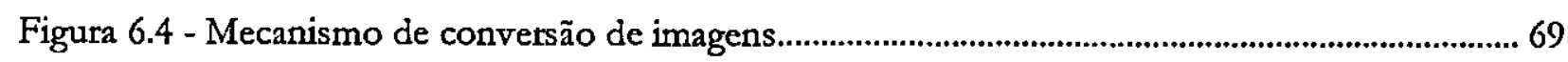

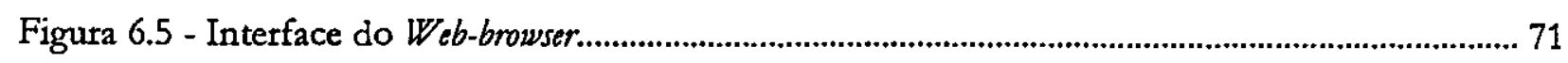

Figura 6.6 - Interface da ferramenta de importação ................................................................................ 72

Figura 6.7 - Determinação dos atributos otganizacionais "Profundidade" e "Exibir imagens"......... 73

Figura 6.8 - Interface para a definição das palavras-chave..................................................................... 74

Figuta 6.9 - Inicio do processo de importação ......................................................................................... 75

Figura 6.10 - Determinação dos atributos do SASHE ......................................................................... 75

Figura 6.11 - Hiperdocumento obtido com o processo de importação .................................................. 76

Figura 6.12 - Nó de informação obtido com o processo de importação ................................................. 77

Figura 6.13 - Inserção de imagem em um hiperdocumento SASHE ...................................................... 78 
Este trabalho apresenta um protótipo de ferramenta, a $\mathrm{Html} 2 \mathrm{Hip}$, que proporciona um ambiente de importação e adaptação de documentos descritos segundo o padrão HTML (HyperText Markup Language) para a representação interna do SASHE (Sistema de Autoria e Suporte Hipermídia para Ensino), que se baseia na estruturação de objetos multimídia, segundo a hierarquia de classes proposta pelo MCA (Modelo de Contextos Aninhados). Além disso, este trabalho estendeu a capacidade do editor de nós de informação do tipo texto do protótipo anterior no que concerne ao processamento de arquivos-texto descritos pelo padrão RTF (Rich Text Format). Dessa forma, o SASHE tornou-se capaz de processar e organizar materiais instrucionais preparados em seu próprio ambiente, no ambiente WWW (World-Wide Web), bem como em processadores de texto comuns. 


\begin{abstract}
This work presents a tool prototype, the $\mathrm{Htm} 2 \mathrm{Hip}$, that provides an importation and adaptation environment of documents described in HTML (Hyper'Text Markup Language) standard for the internal representation of the SASHE (Hypermedia System for Authorship and Supporting Educational Applications), that is based on the structural organization of multimedia objects, proposed by MCA (Nested Contexts Model). Moreover, this work extended the capacity of the information text node editor of the previous prototype concerning the processing of text-files described in RTF (Rich Text Format) standard. This way, the SASHE became capable to process and to organize instructional materials prepared in its proper environment, in the WWW (WorldWide Web) environment, as well as in common word processors.
\end{abstract}




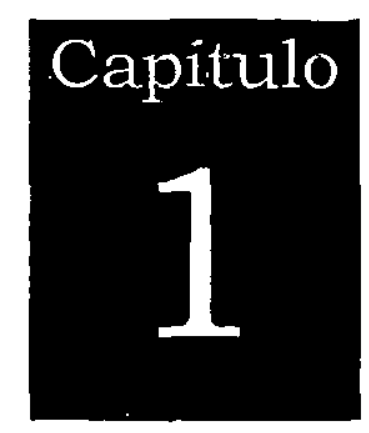

\section{Introdução}

\section{1 - Considerações iniciais}

Recentemente, a aplicação da informática em ambientes de ensino e aprendizagem tem sido alvo de intensas pesquisas. A grande maioria desses trabalhos aponta para a necessidade de se romper as fronteiras da sala de aula convencional e oferecer aos professores a oportunidade de trabalhar seus conteúdos programáticos, proporcionando aos estudantes uma confortável e eficiente construção do conhecimento.

Em particular, os sistemas didáticos que utilizam a tecnologia hipermídia exploram fatores como associação multissensorial, flexibilidade de acesso à informação em toda a sua diversidade (texto, gráficos, áudio e vídeo) e interação, trabalhando com diversas estratégias tutoriais (multimídia, simulações, hipertexto etc.), para prover uma aprendizagem mais efetiva Jacobson et al., 1996; Nunes et al., 1997).

No entanto, a flexibilidade proporcionada pelos sistemas hipermidia traz consigo alguns problemas, pois o usuário (leitor/aprendiz) tende a perder o sentido de localização e direção das informações (desorientação) à medida que navega de uma página para outra em uma estrutura "rasa", ou não- 
hierárquica, de relacionamentos (Conklin, 1987; Dias \& Sousa, 1997). Nesse caso, o usuário acaba desprendendo um esforço adicional de concentração (sobrecarga cognitiva!).

Tentativas de orientação ao usuário têm sido possiveis graças à utilização de roteiros, encontrados na literatura sob diferentes denominações, tais como trilhas (paths) e rotas orientadas (guided-tours). Entretanto, quando toteiros são utilizados em um sistema hipermidia, surge o dilema entre satisfazer os objetivos do autor do hiperdocumento ou preservar a liberdade do usuário (Large, 1996).

Buscando uma alternativa para reduzir a distância entre essas duas estratégias, chega-se à hipermidia adaptativa (Brusilovsky, 1996; Eklund, 1995) que, através da definição de um conjunto de mecanismos de navegação (Adaptative Navigation Support - ANS), apresenta aos usuários roteiros que sejam potencialmente de seu interesse. Conseqüentemente, essa classe de sistemas deve ser capaz de estabelecer um modelo de usuário, garantindo-se, assim, a eficácia de seus hiperdocumentos, ao evitar que o usuário navegue superficialmente pelos relacionamentos dos mesmos.

Por outro lado, num momento em que a palarra de ordem é compartilhar documentos, a expansão da Internet e o correspondente aumento da comunidade de usuários da WWW (World-Wide Web), ou simplesmente Web (Berners-Lee et al., 1994), têm provocado um crescente interesse pela disponibilização de material atualizado nesse ambiente (Pimentel \& Hagui, 1996). Devido às facilidades de autoria, distribuição e acesso, esse material pode ser bastante aproveitável para o ensino.

No entanto, Castro (1997), por sua vez, questiona que buscas em catálogos de informações mostram a dificuldade em encontrar sites ${ }^{2}$ com informações científicas realmente interessantes: "Muitas vezes, a decepção vem na forma de páginas com ênfase no tratamento gráfico e informações pouco relevantes, escassas ou desatualizadas. Nesse caso, o aprendiz pode acabar baseando suas pesquisas em informações que não passaram pelo crivo de um professor, arriscando-se a propagar exros cientificos".

\footnotetext{
'A sobrecarga cognitiva acontece quando o usuário precisa se lembrar de muitos detalhes sobre a sua navegação, ou sobre o funcionamento do sistema, para conseguir se orientar no conjunto de informações (Dias \& Souza, 1997).

2 Um site corresponde a um endereço Internet, que denota um setvidor (bost) que mantem um conjunto de páginas WWW.
} 
Uma solução intuitiva para esse problema pode ser encontrada em Costa e Xexéo (1996), onde o professor, além de fornecer suporte tecnológico, formece endereços iniciais de pesquisa e verifica se as informações consultadas pelos aprendizes são compativeis com os objetivos de ensino almejados.

Todavia, é preciso lembrar que o hipertexto da WWW é diferente do encontrado em sistemas locais, pois além dos problemas tradicionais de navegação em hipertexto (desorientação e sobrecarga cognitiva), a recuperação de informações implica na transmissão de dados em redes heterogêneas (diferentes protocolos, arquiteturas, taxas de transmissão etc.). Nesse caso, a transmissão muitas vezes fica prejudicada devido à estrutura das redes intermediárias. Logo, a demora para recuperar as informações pode quebrar o "fio de pensamento" do aprendiz (Tsybenko \& Bykov, 1997).

\section{2 - Motivação e objetivos}

O protótipo de ambiente de autoria e navegação denominado Sistema de Autoria e Suporte Hipermidia para Ensino (SASHE) (Nunes et al., 1996; Santos, 1997; Santos et al., 1997), desenvolvido no Instituto de Ciências Matemáticas e de Computação (ICMC), dentro do projeto HyperProp (Soares et al., 1995b), permite a autoria de roteiros "flexíveis", possibilitando ao autor estabelecer limites à total liberdade de navegação (Nunes \& Fortes, 1997).

O objetivo não é tentar impedir iniciativas do aprendiz, mas, sim, fornecer recursos ao autor para que critérios como relevância e fidelidade às metas de ensino/aprendizado sejam consideradas. Com isso, procura-se minimizar os riscos de o aprendiz se perder por caminhos irrelevantes.

Dessa forma, a navegação proporcionada para o aprendiz incorpora estratégias tutoriais baseadas na contextualização e qualificação dos componentes do hiperdocumento, ou hiperbase, conforme terminologia do MCA (Modelo de Contextos Aninhados) (Casanova et al., 1991; Soares et al., 1994, 1995a), modelo conceitual hipermídia empregado na estruturação dos objetos (elementos) dos hiperdocumentos criados com o auxilio do protótipo.

O objetivo deste trabalho é conciliar as vantagens do ambiente SASHE com a possibilidade de utilização de material advindo da WWW, de forma que um usuário possa, de posse de um hiperdocumento HTNL, transportá-lo para o ambiente de autoria do protótipo. Nesse ambiente, o usuário pode simplesmente navegar pelo hiperdocumento, como também remodelar a sua estrutura 
organizacional ${ }^{3}$ de acordo com os recursos oferecidos pelo ambiente (apresentados nas seções 5.4.1 e 5.4.2), e com isso obter um material com as características adicionais do SASHE.

Além de investigar um mecanismo de importação de material HTML para a representação interna do SASHE, este trabalho estende a capacidade do editor original de nós de informação do tipo texto, no que concerne ao processamento de arquivos-texto descritos pelo padrão RTF (Rich Text Format).

Dessa forma, o SASHE, agora na versão 2.0, é capaz de processar material instrucional preparado em seu próprio ambiente, no ambiente WWW, bem como em processadores de texto largamente utilizados, como por exemplo, o Microsoft Word for Windows.

\section{3 - Organização}

Este capítulo apresentou o problema a ser investigado, a motivação e os objetivos deste trabalho. No segundo capítulo é feito um levantamento bibliográfico sobre a incorporaçāo de informática, em especial da tecnologia hipermídia, em ambientes de ensino e aprendizagem.

No terceiro capítulo são apresentados alguns ambientes de criação, estruturação e distribuição de material didático na forma de hiperdocumentos.

No quarto capítulo, são apresentados os pressupostos técnicos sobre padrões de representação e intercâmbio de documentos, que foram empregados na fase de implementação do mecanismo de importação e adaptação proposto por este trabalho.

O quinto capítulo é dedicado à apresentação das principais características e funcionalidades dos ambientes de autoria e navegação do SASHE. Também nesse capítulo, encontra-se uma breve descrição do Modelo de Contextos Aninhados. Finalmente, será apresentado um framevvork comparativo entre os ambientes de criação, estruturação e distribuição de material didático, que setão apresentados no capítulo 3 , e os ambientes de autoria e navegação do SASHE.

\footnotetext{
3 Segundo Jonassen e Mandl (1990), a combinação dos elementos nó, elo e âncora determina a organização estrutural de um hiperdocumento. Nesse caso, a maneira pela qual esses componentes são estruturados pode limitar ou expandir os recursos a serem oferecidos pela aplicação. Uma organização estrutural bem definida, além de facilitar a localização e a recuperação das informações, possibilita melhor associação e compreensão das mesmas pelos usuários.
} 
A Html2Hip, um protótipo de ferramenta para importação e adaptação de documentos HTML para a representação interna do SASHE, é apresentada no capítulo 6. Nesse capítulo, também são telatadas as modificações que foram necessárias para que os nós de informação (terminais) do tipo texto do SASHE passassem a processar arquivos descritos segundo o padrão RTF.

Finalmente, no sétimo capítulo encontram-se as conclusões e contribuições deste trabalho, bem como as propostas de trabalhos futuros. 


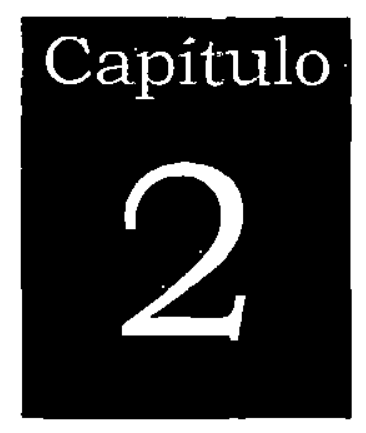

\section{A informática como ferramenta de apoio à Educação}

\section{1 - Considerações iniciais}

A convergência cada vez maior das midias tradicionais para a forma digital, em conjunto com o uso maciço dos computadores por pessoas em seus ambientes profissional e doméstico, vem transformando a maneira de consumir informações, criando uma cultura de comunicação digital (Tapscott, 1997).

Nesse sentido, os sistemas hipermidia possuem aspectos televantes que podem significar um salto qualitativo na Educação: capacidade de individualizar a aptendizagem, facilidade de manipular as informações armazenadas em difetentes mídias propiciando uma aprendizagem multissensorial, desenvolvimento de espirito crítico, e novas perspectivas para o trabalho do professor.

Neste capítulo encontra-se uma revisão bibliográfica sobte a questão da incorporação de informática em ambientes de ensino e aprendizagem. No entanto, uma ênfase será dada à tecnologia hipermídia. Logo, durante a exposição dos conceitos, levantar-se-ão questões sobre a autoria de material didático na forma de hiperdocumentos, bem como as vantagens e desvantagens dessa estratégia. 
A seção 2.2 apresenta alguns dos principais recursos (estratégias' tutoriais) que podem ser empregados em um ambiente computacional de ensino/aprendizagem. Na seção 2.3 são discutidos mecanismos que permitem uma estruturação mais elaborada da hierarquia dos elementos de um hiperdocumento, o que possibilita o desenvolvimento de estratégias navegacionais que reduzem a demanda cognitiva do aprendiz. Finalmente, na seção 2.4 são apresentadas, de maneira resumida, as principais características de alguns métodos para modelagem de aplicaçōes hipermídia.

\section{2 - Recursos empregados no suporte ao ensino e aprendizado}

Atualmente existem duas categorias bem definidas de aplicação dos computadores em ambientes de ensino e aprendizagem: a instrução assistida por computador (Computer-Aided Instruction - CAI) e o treinamento baseado em computador (Computer-Based Training - CBT).

A instrução assistida por computador enfatiza o uso de computadores para a iniciação e promoção dos processos de aprendizado. Nessa categoria, algumas aplicações mais avançadas incorporam técnicas de Inteligência Artificial para adaptar-se às diferentes características de cada usuário, ou seja, utilizam diferentes estratégias tutoriais de acordo com as atitudes tomadas pelo usuátio durante a sua interação com o sistema (Nwana, 1990). Entre essas aplicações destacam-se os sistemas tutores inteligentes ou sistemas de instrução inteligente assistida por computador (Intelligent Computer-Aided Instruction - ICAI).

O treinamento baseado em computador trabalha com ambientes computacionais que visam facilitar o desenvolvimento e aperfeiçoamento de habilidades em domínios específicos de procedimentos (tarefas) (Barker \& Manji, 1992). Esses ambientes, em especial, exploram o uso de simulações.

\subsection{1 - Simulafōes}

A simulação permite a exploração/investigação de situações que seriam dificeis ou perigosas de serem reproduzidas em condições normais, como por exemplo, experiências químicas ou de balística (Jong, 1991).

Outras abordagens incluem a simulação utilizada como ferramenta de investigação (pela proposição e teste de hipóteses), como ferramenta de aprendizado indutivo e/ou dedutivo, ou ainda, como um ambiente de aquisição de conhecimento através da utilização de técnicas de resolução de problemas (Goodyear et al., 1991). 
Valente (1993), por sua vez, comenta que a aplicação de simulações em um ambiente de ensino procura estimular processos cognitivos que transformam informações em conhecimento. Por conseguinte, as simulações devem permitit a exploração e experimentação de situações, oferecendo condições apropriadas de controle e critérios de avaliação adequados aos efeitos reais da simulação.

\subsection{2 - Sistemas de resolufão de problemas}

Segundo Russel e Novig (1995), essa classe de sistemas deve combinar aspectos das modalidades de aprendizagem por descoberta e aspectos mais instrucionais provenientes dos STI's clássicos, pois uma atividade de resolução de problemas pode ocorrer de duas maneiras distintas: o sistema resolve problemas propostos pelo aprendiz ou o contrário.

Em qualquer caso, o sistema deve acompanhar o processo e apresentar o feedback necessário, ou seja, se for solicitado, o sistema procura resolver o problema proposto e apresentar explicações sobre a sua solução.

Dessa forma, a estratégia tutorial dessa classe de sistemas consiste em apresentar uma solução para um dado problema que esteja dentro de um determinado domínio e descrever o mecanismo utilizado para atingir essa solução, na esperança que o aprendiz entenda e adquira a habilidade relacionada ao mecanismo empregado.

\subsection{3 - Modelagem}

Os sistemas que permitem modelagem, segundo Valente (1993), propiciam um ambiente de aprendizagem baseado na resolução de problemas. No entanto, diferem da abordagem anterior, pois neste caso, é o aprendiz que constrói a solução de acordo com regras determinadas pelo programa.

Sendo assim, a estratégia tutorial dessa classe de sistemas consiste em incentivar o aprendiz a obter uma representação formal e precisa de uma solução para um determinado problema, com o aprendizado dos conceitos podendo ocorrer durante o processo de definição dessa representação. 


\subsection{4 - Jogos educativos}

Os jogos de uso geral, que buscam diversão e entretenimento, através de "brincadeiras" ou quebra* cabeças, podem ser tratados como ambientes potencialmente tutoriais/educacionais, pois promovem o desenvolvimento de habilidades de pensamento e raciocínio (Valente, 1993).

A estratégia tutorial dessa classe de sistemas é a de ter o aprendiz como um personagem do contexto ao qual está inserida. Nesse caso, o aprendiz é parte integrante do ambiente, deixando de ser um mero espectador. Esse tipo de ambiente, segundo Valente (1993), deve prover um alto grau de controle do aprendiz, enfatizando os aspectos individuais e a criatividade, uma vez que se centram na descoberta e na invenção de possibilidades de resolução.

\subsection{5 - Hipertexto}

A representação de conhecimento em sistemas de hipertexto permite que diversos elementos (fragmentos) de informação possam ser combinados de diferentes maneiras, de acordo com as perspectivas dos usuários do sistema (Nielsen, 1990). Através de relacionamentos, o hipertexto oferece mecanismos para se descobrir as ligações conceituais entre as seções de assuntos relacionados (Ducan, 1989). Observe o hiperdocumento ilustrado pela Figura 2.1.

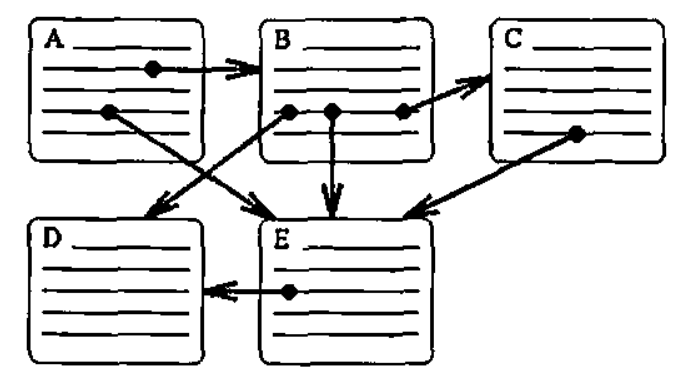

Figura 2.1 - Hiperdocumento simples com 5 nós e 7 elos (Nielsen, 1990)

Assuma que um determinado leitor começou a navegar por esse hiperdocumento pelo fragmento de texto marcado com a letra " $A$ ". Para continuar a leitura, esse leitor não tem apenas uma única opção lógica (no caso de um livro impresso, a próxima página), pois a estrutura desse hiperdocumento oferece para ele duas opções: ler o fragmento de texto " $\mathrm{B}$ " ou " $\mathrm{E}$ ". Imaginemos que ele optou por continuar a leitura pelo fragmento de texto " $\mathrm{B}$ ". Agora, ele pode escolher um dos seguintes fragmentos: " $C$ ", " $D$ " ou " $E$ ". $E$, assim sucessivamente, conforme a sua conveniência. Observa-se, 
então, que em uma estrutura de hipertexto pode-se encontrar diversos "caminhos" que conectem dois fragmentos de informação.

Dessa forma, o sucesso ou fracasso da interação do usuário (leitor) com um hiperdocumento será determinado pelas decisões tomadas pelo autor sobre quais fragmentos de informação devem ser interligados (Ginige et al., 1995). Em outras palavras, para evitar que o usuário fique apenas "passeando" por entre os relacionamentos de um hiperdocumento, de maneira desmotivada e ineficiente, o autor precisa antecipar os usos que o usuário irá fazer da informação apresentada, provendo os elos necessários.

\subsection{6 - Multimídia e Hipermidia}

Multimídia pode ser definida como a apresentação simultânea de informações em diferentes formas de mídia (áudio, vídeo, texto, entre outras) (Buford, 1994).

No entanto, segundo Preece et al. (1994), as pessoas não se utilizam igualmente dos canais sensoriais (visão, audição etc.). Além do mais, quando se tenta atender a mais de um evento ao mesmo tempo, se dá atenção dividida, pois não há concentração suficiente para diversos eventos concorrentes. Dessa forma, segundo Bordenave e Pereira (1988), o emprego de diversas mídias em um ambiente educacional precisa ser planejado de acordo com uma base tutorial/pedagógica, a qual facilite o envolvimento do aptendiz e, por conseguinte, a tetenção dos conceitos apresentados.

A associação entre hipertexto e multimídia define a hipermídia: texto, imagens e sons tornam-se disponiveis na medida em que o usuário percorre os relacionamentos existentes entre eles.

O sistema hipermídia mais difundido da atualidade é a World-Wide Web. Sua independência de plataforma e a possibilidade de agregar diversos recursos e serviços aos documentos apresentados implicam na facilidade de execução de vátios recursos tutoriais, incluindo simulações e interações. Tal sistema utiliza formatos de dados (HTML) e protocolos de acesso (HTTP) abertos, extensíveis e padronizados, que favorecem sua adoção em larga escala.

\section{3 - Mecanismos para o equilíbrio entre o controle do aprendiz e do sistema}

A questão do controle sobte a navegação do leitor em sistemas hipermídia tem sido bastante debatida na literatura. No entanto, quando se restringe à aplicação de tais sistemas no ensino, tal 
questão assume papel vital (Dias \& Sousa, 1997; Freitag \& Sullivan, 1995; Jacobson et al., 1996; Large, 1996; Nunes \& Fortes, 1997).

A liberdade total durante a exploração do material didático resulta em algumas vantagens bastante evidentes: a) o aprendiz, ao navegar livremente pelo hiperdocumento, cria virtualmente uma porção relevante para seus objetivos, que representa uma visão própria do conteúdo; b) o aspecto exploratório induz a participação ativa do aprendiz fazendo-o refletir sobre o material; c) as ligações estabelecidas pelo autor fazem transparecer uma estrutura lógica muitas vezes não visível em outro tipo de representação; d) tendo controle sobre o processo de aprendizagem, o aprendiz é capaz de aprender como aprender, e) ao tomar decisões instrucionais, o aprendiz descobre as melhores táticas para diferentes situações.

Por conseguinte, ao ter controle sobre o material instrucional, o aprendiz naturalmente se sente mais motivado e aliviado de frustrações e ansiedades, uma vez que é capaz de ignorar tópicos que ele já domina (ou pensa que domina) ou que não deseja ter acesso e, conseqüentemente, se concentrar naquilo que considera mais relevante. Todavia, a demanda cognitiva sobre ele é certamente maior.

Do ponto de vista do usuário (leitor/aprendiz), uma falta de orientação mais objetiva pode, no mínimo, retardar o alcance de seus objetivos. A tão propagada liberdade do usuário deve, em muitos tipos de aplicação, ser ponderada: certamente ele não quer ser cerceado, mas tem também alguma meta a alcançar.

Tentativas de orientação ao usuário têm sido possíveis, por exemplo, graças à utilização de roteiros planejados pelo autor do hiperdocumento para esse fim.

\subsection{1 - Roteiros como forma de controle e orientąão}

A questão do controle da interação do usuário em um sistema hipermídia, utilizando-se roteiros, apresenta dois extremos (Nunes \& Fortes, 1997).

Num dos extremos, um roteiro pode impor uma seqüência rígida de nós a serem visitados, ou seja, esses roteiros caracterizam-se por ser uma seqüência de nós e, portanto, com ligações de "próximo" (next) e "anterior" (previous) implicitamente inseridas quando da formação da seqüência. Certamente esse tipo de roteiro parece representar um retrocesso tecnológico: tal procedimento tem sido utilizado desde os primórdios da aplicação da computação em ambientes de ensino e aprendizagem, e a tecnologia hipermídia avançou exatamente quanto a essa limitação. Nessa estratégia, o usuário 
somente tem acesso a material extra-roteiro que esteja dentro da hierarquia de relacionamentos permitida pelo autor do hiperdocumento.

No outro extremo, encontra-se uma abordagem mais descompromissada quanto à autoria de roteiros, pois além da seqüuência propriamente dita, um roteiro pode manter no espaço navegacional todas as demais associações entre seus nós (visualizadas attavés de âncoras), promovendo, assim, uma visão mais getal do dominio sendo apresentado. Nessa estratégia, o usuário pode eventualmente "fugir" do roteiro conforme sua conveniência.

A situação ideal seria um meio-termo entre os dois extremos, ou seja, a possibilidade de se criar roteiros que mantenham associações originais e que estas, por sua vez, segundo Nunes e Fortes (1997): a) sejam relevantes ou não prejudiciais aos objetivos do autor'; b) promovam uma leitura mais flexível; e c) possam contribuir para o alcance dos objetivos do usuário.

No protótipo de ambiente de autoria e navegação SASHE, apresentado no capítulo 5, esse equilíbrio pode ser estabelecido pelo autor, através da contextualização e qualificação dos elementos de seus hiperdocumentos. Essa característica permite a autoria de roteiros "flexíveis", ou seja, com escopos variados de liberdade de navegação.

\subsection{2 - Nós de contexto}

A utilização de nós de contexto ou de composição tem um papel importante nesse cenário, pois o agrupamento lógico de nós que tratam de um tema comum possibilita uma melhor organização da informação e requer uma melhor elaboração por parte do autor.

A maioria dos modelos para hiperdocumentos abriga nós de contexto ou composição, tal como o HDM (nó-raiz) (Garzotto et al., 1993) e OOHDM (classe de nós) (Schwabe et al., 1996). No entanto, apresentam algumas limitações, como a não possibilidade de aninhamento de composições, que conseqüentemente exige dos autores um procedimento de controle ainda maior.

O Modelo de Contextos Aninhados (MCA) (Casanova et al., 1991; Soares et al., 1994, 1995a), base do sistema HyperProp (Soares et al., 1995b), é um modelo conceitual de dados hipermídia que tem

\footnotetext{
+ Os objetivos do autor $\mathrm{e}$ do usuário (leitor/aprendiz) podem ser coincidentes. Estamos assumindo, aqui, que tanto o autor (professor) quanto o aprendiz têm como objetivo comum o aprendizado. No caso de objetivos conflitantes, a utilização de roteiros serviria unicamente aos objetivos do autor.
} 
como principal característica o tratamento de nós de composição (ali chamados de nós de contexto) que podem ser recursivamente aninhados.

A possibilidade de se aninhar contextos/composições permite ao autor definir a extensão ou grau de liberdade associado a um nó terminal (texto, áudio, imagem etc.) que ele selecionou para o toteiro. Em outras palavras, ao selecionar um nó terminal que pertença a um aninhamento de contextos (no MCA, sempre há, no mínimo, um contexto, que é o que abriga todo o hiperdocumento), o autor pode determinar o maior contexto que o contém e que pode fazer parte do roteiro. Isso significa que, ainda que os demais nós deste contexto não tenham sido diretamente selecionados para compor o roteiro, todas as ligações e correspondentes âncoras pertencentes a esse contexto ficam acessíveis durante a apresentação do nó terminal selecionado. Intuitivamente, o que o autor faz é permitir que o usuário navegue por aquele contexto, uma vez que ele considera que essa "fuga" não é prejudicial aos seus objetivos.

Como exemplo, observe o hiperdocumento ilustrado pela Figura 2.2.

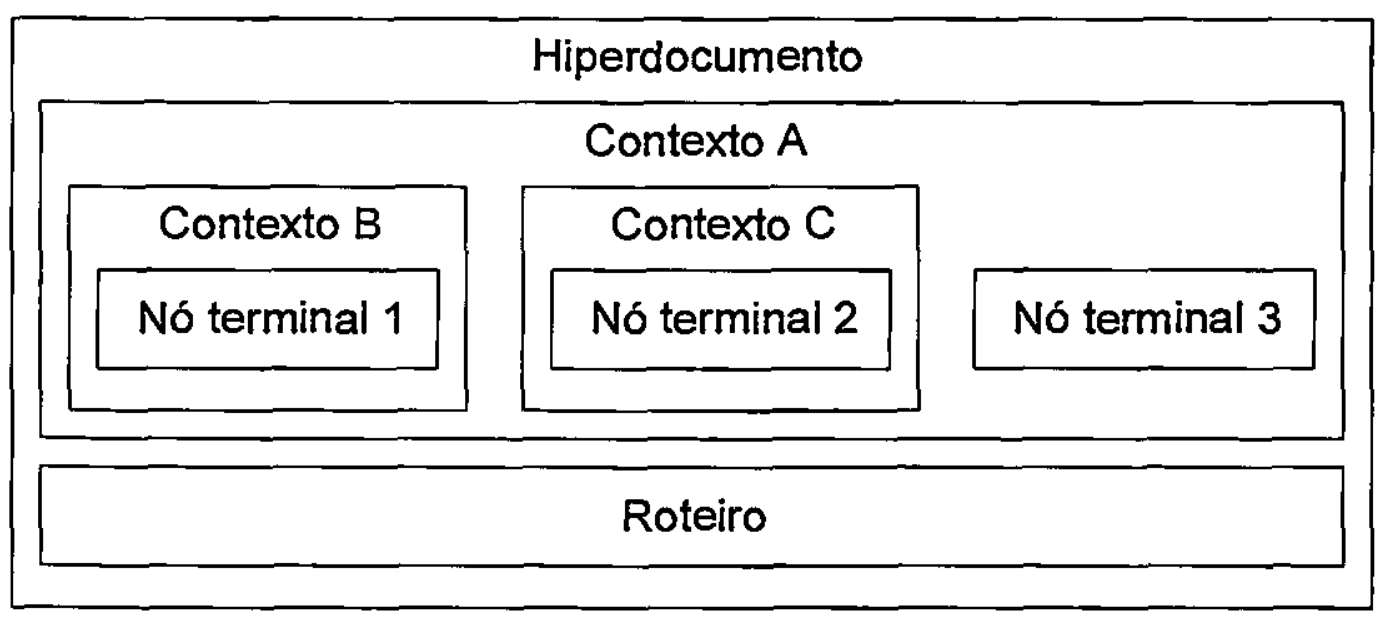

Figum 2.2 - Representação gráfica de um hiperdocumento (Santos, 1997)

Um possível roteiro poderia ser o esquematizado pela Tabela 2.1:

Tabela 2.1 - Descrição de um possivel toteiro

\begin{tabular}{|l|c|c|c|}
\cline { 2 - 4 } \multicolumn{1}{c|}{} & Primeiro nó & Segundo nó & Terceiro nó \\
\hline Nó principal & Nó terminal 1 & Nó terminal 2 & Nó terminal 3 \\
\hline Nó liberdade & Contexto A & Contexto C & Nó terminal 3 \\
\hline
\end{tabular}


1. Quando o primeiro nó for apresentado, o aprendiz terá acesso a todas as informações (nós e elos) aninhadas no contexto " $A$ ", ou seja, todos os demais elementos do contexto " $A$ " ficam visíveis (na verdade, acessiveis através de elos) a partir do primeiro nó;

2. O segundo nó restringe um pouco mais o acesso, pois somente as informações aninhadas no contexto C estarão acessíveis;

3. Já no terceiro nó, a restrição é máxima, pois o nó liberdade é igual ao nó ptincipal, ou seja, somente as informações contidas no Nó Terminal 3 serão visualizadas. Isso implica que qualquer tentativa de navegação, via âncoras definidas nesse nó, será frustrada.

\subsection{3 - Atributos de nós}

Enquanto que a maioria dos modelos de sistemas hipermídia é rica quanto ao número de tipos diferentes de nós que podem compor um hiperdocumento, deixam a desejar quanto a recursos para a qualificação desses nós com respeito ao seu conteúdo (Nunes \& Santos, 1998). O uso de palavras chave, por exemplo, é bastante comum e útil, porém insuficiente para atividades como a de selecionar, mais criteriosamente, os nós que devem compor um roteiro.

Uma vez tendo os nós do hiperdocumento qualificados de acordo com os atributos pertinentes à aplicação, o autor pode definir outros mecanismos de interação para o aprendiz (possivelmente na forma de botões visíveis na navegação), que seriam essencialmente estratégias de controle do navegador.

No ambiente SASHE, por exemplo, o autor de uma aplicação (hiperdocumento) de ensino pode definir diferentes estratégias de controle para situaçōes em que o aprendiz se encontra em dificuldade. Assim, se o aprendiz considem um tópico extremamente difícil, ele pode expressar isso através da ativação de uma função (botão) que implementa uma estratégia definida pelo autor. Notase que, para que isso seja possível, tudo o que o sistema de navegação necessita é da informação dos valores de atributos que devem guiar sua busca e o que fazer no caso de insucesso.

A proposta do uso de contextos e atributos para a criação de roteiros e de recursos adicionais ao controle da navegação vem ao encontro do objetivo de possibilitar a autoria de roteiros que incluam informações relevantes e adequadas aos objetivos do autor e do usuário, uma vez que: a) a relevância e adequação dos nós que compõem um roteiro podem ser facilmente estabelecidas por meio da determinação de um contexto-limite (grau de liberdade) e de uma seleção baseada nos atributos 
associados a cada nó; b) a possibilidade de se criar funções adicionais de controle à navegação possibilita uma leitura mais flexível e informativa; c) o alcance dos objetivos do usuário pode ser facilitado na medida em que o autor for capaz de melhor compor sua mensagem, e o usuário possa, então, recuperá-la através de variados recursos.

Pesquisas mais recentes defendem o uso de hipermidia adaptativa (Brusilovsky, 1996; Eklund, 1995) para o desenvolvimento de roteiros flexíveis em aplicações hipermídia destinadas ao ensino. A essa nova estratégia Danielson (1997) dá o nome de ensino adaptativo.

\subsection{4 - Hipermidia adaptativa}

A grande maiozia das aplicações hipermídia permite navegação livre e apresenta o mesmo material para todos os usuários. Porém, diferentes usuários possuem diferentes habilidades (de aptendizado, concentração e abstração), diferentes objetivos e diferentes níveis de intimidade com a utilização de computadores (Eklund et al., 1997; Preece et al., 1994).

Sendo assim, para se construir um ambiente educacional interativo, em vez de um mero "hiper-livro eletrônico", é necessário prover um mecanismo de adaptação individual que, de forma dinâmica, conduza o aprendiz por entre as informações e seus relacionamentos, levando em consideração o seu conhecimento anterior, sua habilidade de compreensão e seus interesses.

Quando aplicados em ambientes de ensino e aprendizado, baseando-se na navegação de seus usuários, os sistemas hipermídia adaptativos se "adaptam" (modificam sua estrutura organizacional), exibindo somente informações que forem realmente relevantes para o aprendizado específico de cada usuário (Brusilovsky, 1996; Danielson, 1997; Eklund et al., 1997). Por conseguinte, definem um modelo de usuário, o qual determina quando, quanto e quais informações devem ser apresentadas.

Mais especificamente, para "guiar" seus usuários, os sistemas hipermidia adaptativos utilizam-se de um conjunto genético de mecanismos de navegação chamado Suporte à Navegação Adaptativa (Adaptative Navigation Support - ANS) (Brusilovsky, 1996). Esses mecanismos (direct guidance, adaptative ordering, biding e adaptative anotation) determinam quais links setão ou não visualizados por um dado usuário dentro de seu espaço navegacional. 
Os sistemas hipermídia adaptativos mais conhecidos da atualidade são o InterBook ${ }^{5}$ (Brusilovsky et al., 1996) e o ELM-ART' (Episodic Learner Model The Adaptive Remote Tutor) (Schwarz et al., 1996).

\section{4 - Métodos para modelagem de aplicações hipermídia}

Com o surgimento das ferramentas WYSIWYG", qualquer pessoa tornou-se capaz de "montar" um conjunto de hiperdocumentos interativos.

No entanto, em sistemas de autoria hipermidia tradicionais (como os comerciais AuthoWare, Director e Toolbook), os autores encontram apenas recursos genéricos e paliativos que podem auxiliá-los na confecção de fragmentos de informação (páginas) e de roteiros. Toda estratégia navegacional (e, por conseguinte, tutorial) deve ficar implícita na organização estrutural criada pelo autor.

Por sua vez, Garzotto et al. (1993) comenta que a utilização de um modelo, ou de um método para modelagem de aplicações hipermídia (hiperdocumentos), pode auxiliar o autor na atividade de autoria, pois permite que ele trabalhe em um nível de abstração mais próximo ao domínio de aplicação, entre outras vantagens.

Nesse sentido, vários métodos têm sido propostos para descrever o processo de desenvolvimento e os aspectos de domínio e de navegação das aplicações hipermídia. Abaixo, encontra-se uma breve descrição de alguns dos principais métodos encontrados na literatura que propõem a modelagem de aplicações hipermídia:

- HDM (Hypertext Design Model) (Garzotto et al., 1993) é um método de projeto preocupado em modelar o domínio da aplicação com o objetivo de diminuir os problemas típicos da utilização de sistemas hipertexto: desorientação e sobrecarga cognitiva. Com esse método, o domínio de uma aplicação pode ser modelado através de um esquema composto por um conjunto de tipos de estruturas de informação (entidades, componentes e unidades) e de ligações (estruturais, de aplicação e de perspectiva), no qual cada estrutura de informação é constituída por uma hierarquia de componentes que podem ser analisados sob diferentes perspectivas. Com isso,

\footnotetext{
5 InterBook Homepage: http://wrvw.contrib.nndrew.cmu.edu/ plb/InterBook.html

“ ELMI-ART Homepage: http://www.psychologie.uni-trier.de:8000/projects/ELM/clmart.html

7 WYSIWYG: “What You See Is IWhat You Get” - ambiente no qual o usuário edita documentos (texto, imagens, ctc.) visualizando o resultado final.
} 
segundo Bieber e Vitali (1997), aspectos sofisticados de navegação podem ser obtidos com a utilização do HDM.

- OOHDM (Oject-Oriented Hypermedia Design Metbod) (Rossi, 1996; Schwabe et al., 1996) é um método voltado para o desenvolvimento de aplicações hipermidia que descreve as tarefas a serem executadas desde a análise do domínio da aplicação até a sua implementação. Trata-se de uma evolução do HDM, porém incorporando uma série de novos conceitos vindos, sobretudo, da orientação a objetos. O OOHDM propõe que o desenvolvimento de aplicações hipermídia seja um processo dividido em quatro etapas: modelagem conceitual, modelagem da navegação, projeto abstrato da interface e implementação.

- RMM (Relationship Management Metbodology) (Isakowitz et al., 1995) é um método de desenvolvimento de aplicações hipermídia indicado principalmente para as aplicações que apresentam estrutura regular de domínio e que necessitam de freqüentes atualizações, como por exemplo, um catálogo de produtos. O método compreende sete etapas: projeto de E-R, projeto de entidade, projeto de navegação, projeto de protocolo de conversão, projeto de interface de usuário, projeto de comportamento em tempo de execução e implementação.

Entretanto, os métodos disponiveis atualmente para hipermidia procuram a generalização de dominio, perdendo informações importantes sobre as características de um domínio mais específico. No caso de um ambiente de autoria de aplicações hipermídia destinadas ao ensino, o que se deseja garantir ao autor é a possibilidade de elaboração cuidadosa de sua mensagem, permitindo-lhe incluir nela o que for essencial ou relevante, sem eliminar o secundário, o complementar, desde que este não entre em conflito com o essencial e que possa contribuir para os objetivos do aprendiz.

Além disso, ao aceitar qualquer domínio, esses métodos tendem a utilizar modelos de representação que são estranhos aos autores, fazendo com que estes tenham dificuldade em modelar o material instrucional.

Portanto, existe uma necessidade de métodos de modelagem hipermídia mais dedicados ao ensino, os quais além de facilitar a tarefa do autor, também contribuam para que os objetivos de aprendizagem do aprendiz sejam atendidos.

O Método para Projeto de Hiperdocumentos para Ensino, ou EHDM (Educational Hyperdocuments Design Metbod) (Pansanato, 1999), tem como principal objetivo auxiliar o desenvolvimento de 
hiperdocumentos educacionais. $O$ método compreende três fases distintas: modelagem conceitual hierárquica, projeto navegacional de contextos e construção e teste.

A fase de modelagem conceitual hierárquica consiste em estruturat o domínio de conhecimento através da classificação dos tópicos da teoria que será abordada em categorias de conhecimento prédefinidas e do estabelecimento de relações entre as partes. O projeto navegacional de contextos deriva um modelo navegacional de contextos (nós, elos e estruturas de acesso) do modelo conceitual hierárquico criado na fase anterior. Na fase de construção, um hiperdocumento real é obtido através de um processo de tradução (mapeamento) do modelo navegacional de contextos para uma plataforma hipermidia. Nessa fase também ocorrem os testes, que procuram identificar os erros ocorridos na construção do hiperdocumento.

\section{5 - Considerações finais do capítulo}

A aplicação de informática na Educação ainda constitui um tópico bastante polêmico e debatido. $O$ surgimento de novas propostas certamente contribui com subsídios para discussões sobre a conveniência e as vantagens (ou desvantagens) oferecidas pelos sistemas computacionais inseridos em ambientes de ensino e aprendizagem.

No entanto, empregar novas tecnologias não implica em sucesso no aprendizado. Acima de tudo, é necessário haver motivação das pessoas envolvidas com a nova ferramenta, dando oportunidade ao surgimento de uma nova maneira de ensinar e aprender. Dessa forma, antes de mais nada é preciso preparar os aprendizes para um pensamento crítico e reflexivo (construtivismo), e incentivar e facilitar o treinamento e preparação dos professores para essa nova perspectiva educacional.

Por outro lado, investimentos em informática (processadores cada vez mais rápidos e baratos, maior capacidade de armazenamento a um custo menor etc.) e tecnologias de comunicação de dados (redes de alta velocidade, protocolos simples e eficientes etc.) têtn contribuído para a explosão do uso de computadores e para a popularização da Internet.

Conseqüentemente, segundo Romiszowsky (1997), a área educacional vem experimentando um processo gradativo de migração para o meio computacional, em particular para a World-Wide Web. Dessa forma, é fundamental lançarmos um olhar atento aos ambientes educacionais disponiveis, pasa verificar se tais ambientes permitem a construção de cenários educacionais inovadores, como os propostos por Campbell et al. (1995) ou por Schank (1994). 
No próximo capítulo serão apresentadas as principais características de alguns projetos que visam estimular o uso dos computadores como ferramenta de apoio ao ensino no contexto da World-Wide Web. 


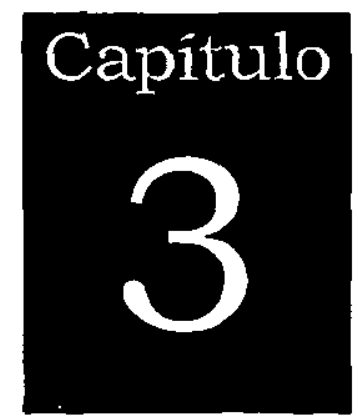

\section{Ambientes de autoria, estruturação e distribuição de material didático}

\section{1 - Considetações iniciais}

Atualmente, a Internet põe à disposição de seus usuários, um número consideravelmente grande de possibilidades educacionais, que podem ser englobadas em: a) conjuntos isolados de ferramentas de comunicação e cooperação; b) ambientes integrados de aprendizagem; e c) sistemas de autoria para construção de cursos virtuais.

As próximas seções apresentam as principais características de alguns ambientes (distribuidos ou não) que procuram facilitar a criação (autoria), estruturação e distribuição de documentos interativos com finalidades educacionais.

\section{2 - O sistema Interland}

O projeto HyDTS (Hypermedia Distributed Teacbing System) (Moreira et al., 1995), atualmente denominado Interland, propõe um sistema direcionado para atividades de treinamento e ensino 
assistido no qual, animações, vídeos, simulações e hiperdocumentos são fartamente utilizados como ferramentas de auxilio ao aprendizado.

A estrutura do protótipo atual baseia-se na arquitetura da WWW (ambiente distribuído composto por um ou mais servidores e vários clientes remotos ou locais), e permite a incorporação de programas auxiliares (componentes) com tarefas específicas.

Esses componentes aparecem na forma de CGI scripts ou applets Java, e são utilizados em atividades de: a) acompanhamento/avaliação; b) enriquecimento do material didático com a adição de diferentes estratégias de ensino (simulações, vídeos etc.), e c) comunicação (correio-eletrônico, videoconferência, bate-papo etc.) (Castro et al., 1997).

O protótipo atual, conforme ilustrado pela Figura 3.1, implementa a interface do usuário (aprendiz) na qual, um formulário na página inicial solicita a entrada de seu nome e senha, além da escolha, em um menu pull-down, de uma das disciplinas disponíveis no servidor.
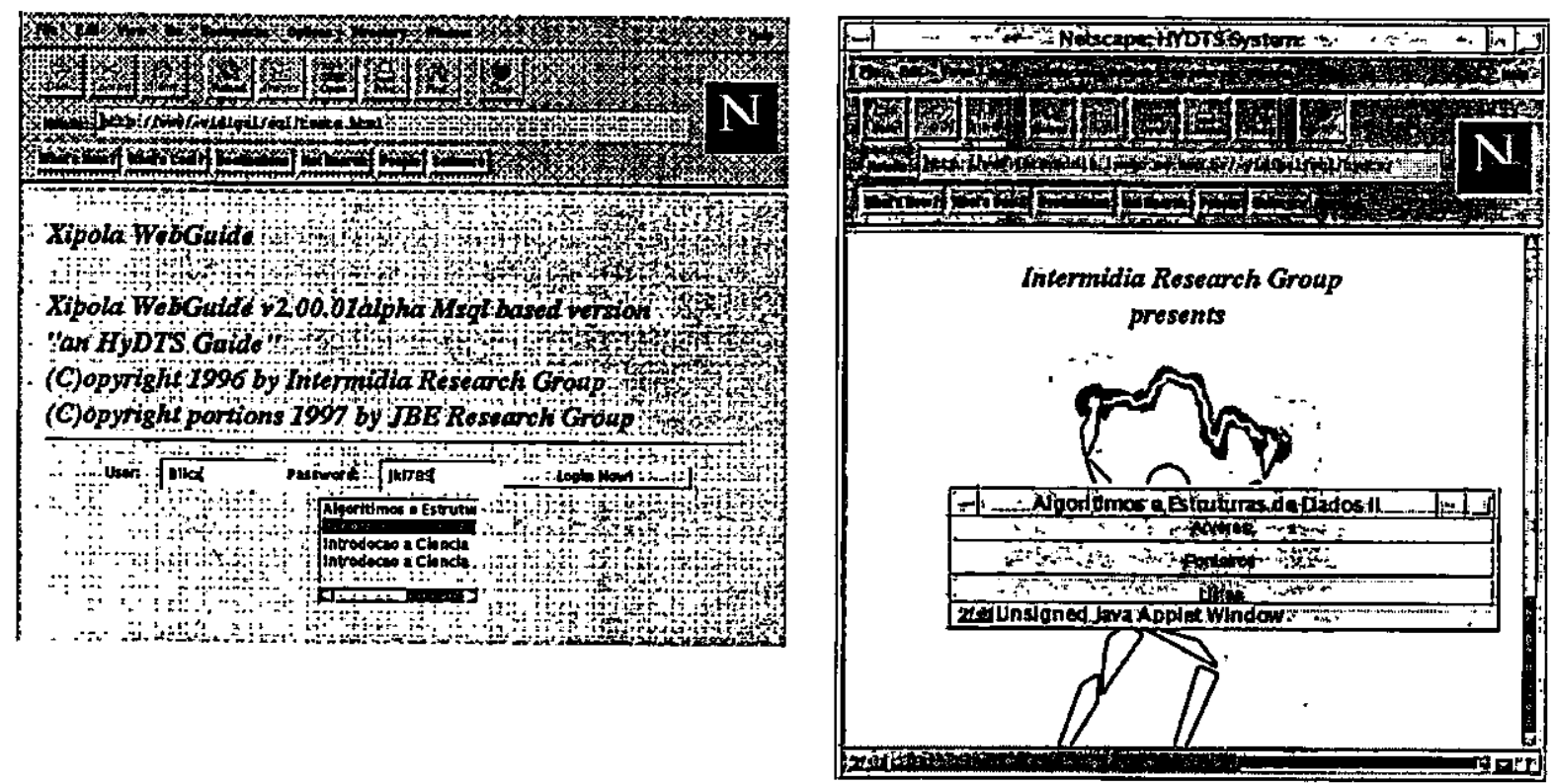

Figura 3.1 - Sistema Interland (interface do aprendiz)

Em seguida, o módulo de autenticação realiza uma verificação na base de usuários, validando-o ou não. Se o usuário for válido, além de um cookie" contendo várias informações pessoais (nome, nível

\footnotetext{
${ }^{8}$ Os cookies são pequenos arquivos que alguns sites da $\mathbb{W} e b$ gravam no computador de seus visitantes. $A$ idéia é identificar o usuário, anotar quais caminhos ele já percorreu dentro do site, permitindo um controle mais eficiente.
} 
de acesso, tempo máximo de acesso etc.), ele recebe um guide-painel com os tópicos, disponíveis no servidor, da matéria selecionada.

Para um usuário professor/autor, o sistema não exigirá a especificação de uma matéria. Assim que sua entrada for validada no sistema, será exibido um ambiente de autoria com diversas ferramentas de trabalho.

\section{3 - O sistema T. A.}

O Sistema "Assistente de Ensino" (Teaching Assistant) foi proposto para auxiliar o professor na tarefa de preparação do material didático dentro do sistema Interland. Suas principais funções, segundo Castro (1997), são: a) oferecer modelos e conjuntos de páginas WWW que visem uma estrutura simples e eficiente para a preparação de material didático; b) prover ferramentas para o desenvolvimento de scripts, permitindo, assim a inclusão de recursos interativos e multimídia no material; c) apresentar informações relacionadas a aprendizes e grupos de aprendizes, pata fins de avaliação e acompanhamento de desempenho; e d) permitir acesso a aplicativos para a montagem de aulas (ou sessões, conforme terminologia do Interland).

Os modelos de aula estão disponiveis para o professor sob a forma de templates (esqueletos de arquivos) do Microsoft Word, Microsoft PonerPoint, e editores específicos de HTML (como o Microsoft FrontPage, entre outros).

Para cada disciplina (conforme ilustrado pela Figura 3.2) existe um conjunto básico de páginas subdivididas em: "Web de Disciplina" (cronograma, glossário, avisos do professor e FAQ"), Apostila, Slides e Material de Apoio.

\footnotetext{
${ }^{9}$ Frequently Asked Questions (F.AQ): documento impresso ou conjunto de páginas interativas em que se costumam reunir respostas a perguntas feitas com maior freqüência pelos usuários de um determinado sistema computacional.
} 


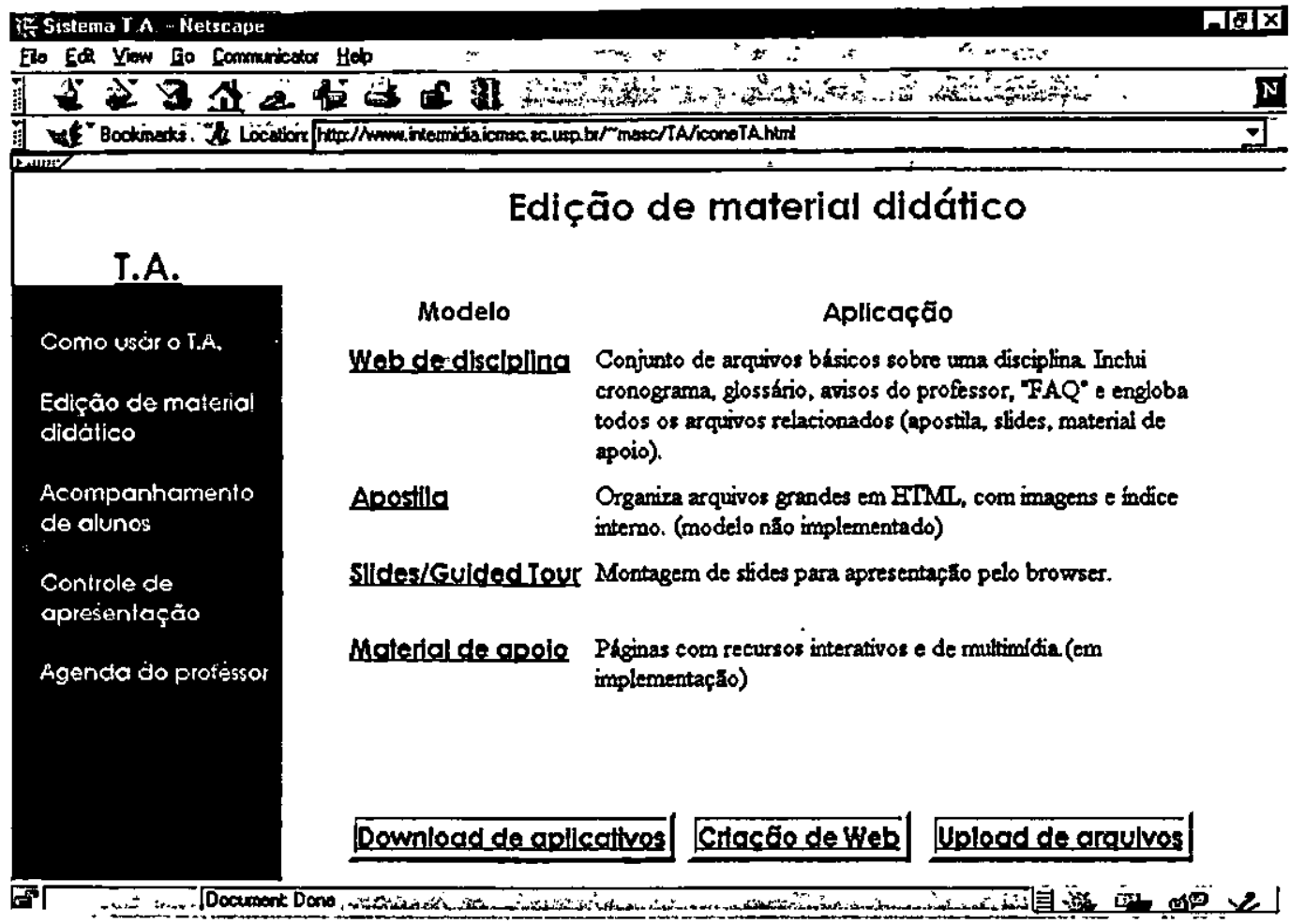

Figura 3.2 - Módulo de edição do T. A. (Castro, 1997)

Uma agenda on-line (agenda do professor) auxilia o professor a controlar as atividades relacionadas a uma determinada disciplina através da ativação de lembretes durante seu login no sistema Interland. Além disso, essa agenda pode disparar e-mails programados para lembrar prazos e outros compromissos aos aprendizes cadastrados em um determinado curso.

\section{4 - HyperBuilder, QuestBuilder e TaskBuilder}

Este projeto, segundo Santos (1998), corresponde à implementação de ferramentas que permitem a autoria de hiperdocumentos com finalidades educacionais, a autoria de questionários de avaliação do aprendizado, a autoria de testes de múltipla escolha baseados em textos e imagens e a publicação desse material no ambiente WWW.

Uma característica fundamental desse pacote de ferramentas é que durante o processo de criação do material didático, o autor não precisa ter conhecimentos prévios sobre detalhes técnicos das linguagens de desenvolvimento para a WWW (tal como HTML, Java, JavaScript e outras tecnologias afins), pois essas ferramentas atuam como uma "casca" (camada) que separa seus usuários dessas tecnologias. 
A ferramenta HyperBuilder (Figura 3.3) promove a orientação ao professor (autor) na inserção de tópicos no texto didático, obedecendo-se uma estruturação pré-definida por.Pimentel et al. (1998). Para gerar o conteúdo correspondente aos itens e subitens, o professor deve carregar o arquivo, gerado pela ferramenta, em um editor de documentos HTML convencional.

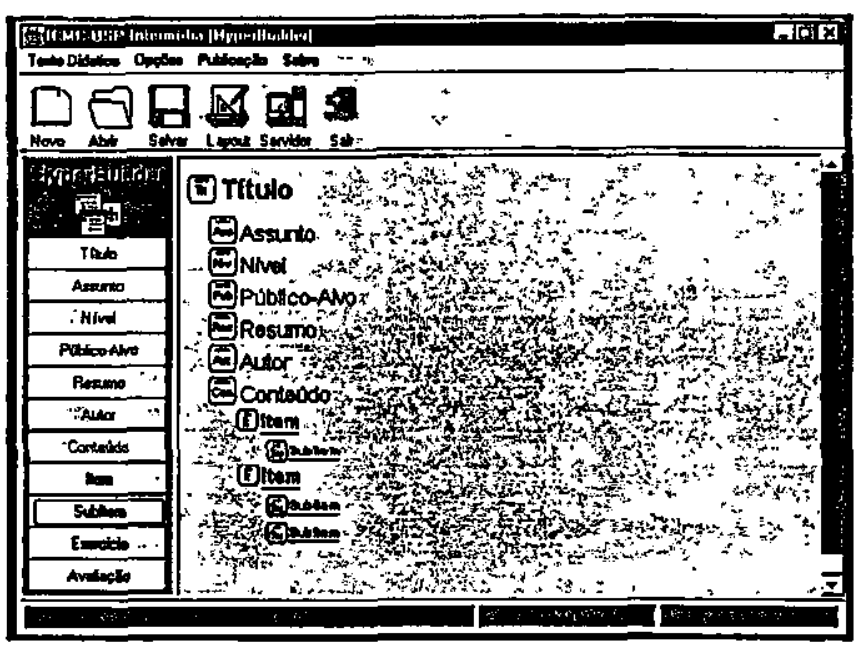

Figura 3.3 - Interface da ferramenta HyperBuilder

$\mathrm{Na}$ ferramenta QuestBuilder, o autor encontra suporte para criação de questões dissertativas, questões de múltipla escolha, questões de falso e verdadeiro, e questões que envolvem o relacionamento de colunas (matcbing).

Além de questionários de avaliação, foi especificado um item denominado "exercício" que permite a inserção de um teste de múltipla-escolha na estrutura do texto didático. Para isso, o autor tem à sua disposição uma ferramenta denominada TaskBuilder.

Finalmente, o processo de disponibilização do material utiliza-se dos recursos da classe FTP (File Transfer Protocol) presente na linguagem Java. Dessa forma, quando o autor seleciona a opção de publicação (publishing), é estabelecida uma conexão com o WebServer desejado e, então, realizado o processo de transferência dos arquivos para uma área pública do referido servidor.

\section{5 - O ambiente AulaNet}

AulaNet (Lucena et al., 1997) é um ambiente para a administração, criação, manutenção e assistência de cursos na WWW, desenvolvido no Laboratório de Engenharia de Software do Departamento de Informática da PUC-Rio. 
O principal objetivo desse projeto consiste em promover a adoção da Web como um ambiente educacional, que permita a criação do conhecimento, tanto por aprendizes, quanto por professores.

Dessa forma, o AulaNet se apóia nas seguintes premissas básicas: a) os cursos criados devem possuir grande capacidade de interatividade, de forma a atrair a participação intensa do aprendiz no processo de aprendizado (learningware); b) o autor do curso não precisa ter conhecimentos prévios sobre as tecnologias empregadas no desenvolvimento de hiperdocumentos $W e b$; c) os recursos oferecidos para a criação de cursos devem corresponder aos de uma sala de aula convencional, acrescidos de outros normalmente disponíveis no ambiente $W e b$; e d) deve ser possivel a reutilização de conteúdos já existentes em mídia digital, através, por exemplo, da importação de arquivos.

No ambiente de autoria e no ambiente de navegação do AulaNet são encontrados mecanismos de: a) comunicação (correio-eletrônico, grupos de interesse/discussão e vídeo-conferência) que possibilitam a interação entre professor e aprendiz e entre aprendizes; b) coordenação (agenda, noticias do curso, exercicios, provas etc.) para planejamento de tarefas e atividades de avaliação; e c) mecanismos de cooperação (transparência, texto de aula, livro texto, bibliografia, co-autoria de aprendiz etc.) que correspondem ao instrumental pedagógico a ser utilizado durante a aplicação do curso.

A Figura 3.4 ilustra um exemplo de uma aula que contém recursos de vídeo, transparência e texto de aula.

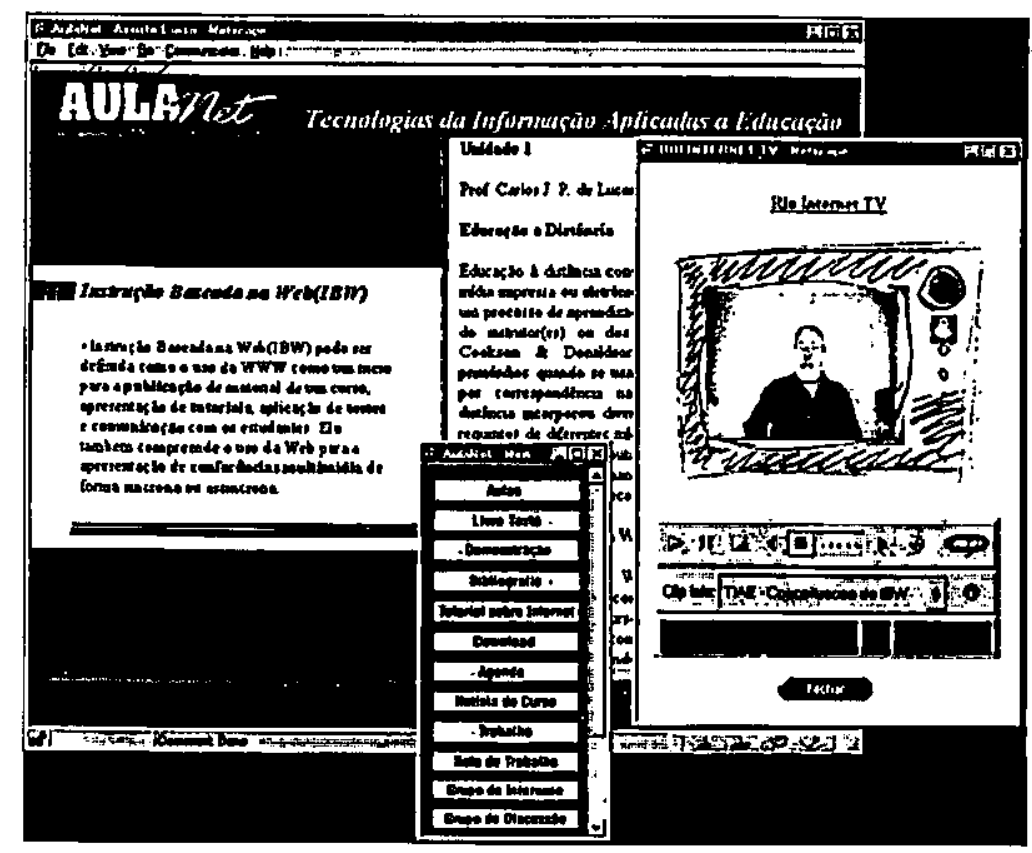

Figura 3.4 - Interface do aprendiz no AulaNet (AulaNet, 1999) 


\section{6 - InterBook}

O sistema InterBook (Brusilovsky et al., 1996) consiste de um ambiente de autoria que oferece ferramentas para a publicação de livros-texto na World-Wide Web, aos quais podem ser associados índice, glossário e uma interface de busca. A Figura 3.5 ilustra um livro-texto criado com o auxilio do InterBook.

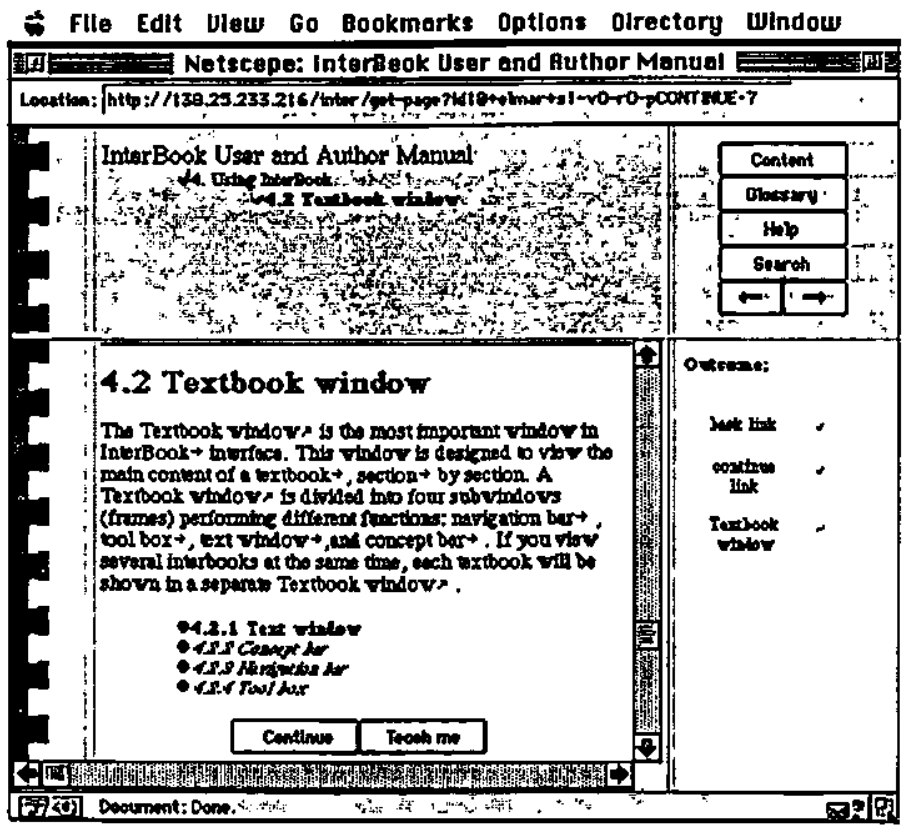

Figura 3.5 - Livro-texto criado com o InterBook (Brusilovsky et al, 1996)

O InterBook suporta navegação seqüencial e hierărquica entre as unidades. Utilizando-se de bullets coloridos, os links têm seu status marcado com base no histórico da navegação, da etapa de conhecimento e dos pré-requisitos. Além disso, cada unidade possui uma ligação para um glossário dos conceitos envolvidos, e ligações (índices) para outras unidades que também estão relacionadas com estes conceitos.

Durante o processo de autoria de um livro-texto, o autor fornece os títulos das unidades (capítulos, seções e subseções) de forma hierárquica (como um livro), sendo que, para cada unidade, pode ser inserida uma anotação que fornece o conjunto de conceitos relacionados com a unidade e o papel do conceito na unidade (pré-requisito ou resultado) (Eklund et al., 1997). A partir das anotações, o sistema reconhece quais conceitos são apresentados em cada página e quais conceitos têm de ser aprendidos antes de exibir/apresentar cada página, proporcionando a utilização de diversas técnicas de adaptação. 


\section{$3.7-W e b C T$}

O WebCT (World-Wide Web Course Tool) consiste em uma ferramenta que facilita a criação de sofisticados ambientes educacionais inteiramente baseados na WWW (Goldberg et al, 1996).

O desenvolvedor do curso (autor) é o responsável por prover o seu conteúdo. A interatividade, estrutura navegacional $e$ as ferramentas educacionais são fornecidas pelo ambiente, que também permite a incorporação de funcionalidades adicionais (tais como ferramentas para verificação do progresso do aprendiz, elaboração de testes, gerenciamento de aprendizes etc.) e a alteração do layout do curso.

$O$ aprendiz encontra no WebCT mecanismos sofisticados de navegação, interação (whiteboard ${ }^{\pi o}$ compartilhado e interativo) e comunicaçāo (correio-eletrônico, listas de discussão e bate-papo).

No entanto, apesar dos muitos recursos oferecidos pelo ambiente WebCT, o emprego de uma estrutura proprietária para os documentos gerados dificulta os processos de reuso e intercâmbio com outros ambientes de autoria e apresentação.

\section{8 - Considerações finais do capítulo}

As novas tecnologias computacionais e de comunicação, além de liberat aprendizes e professores das limitações de tempo e espaço, enriquecem os ambientes de ensino/aprendizagem, possibilitando o estudo individualizado e colaborativo.

Nesse sentido, segundo Menezes et al. (1998), a WWW se apresenta como uma tecnologia capaz de atender às expectativas dos pesquisadores da área de ensino à distância, proporcionando soluções para o problema do oferecimento de educação e treinamento em larga escala, permitindo a publicação de material didático, aplicação de tutoriais e comunicação com, e entre, os aprendizes.

10 Whiteboard é o nome dado ao recurso de compartilhamento de uma tela entre vários usuários. Nesta tela pode ser visualizado um documento ou uma imagem, e os usuários, por sua vez, podem fazer anotaçōes ou marcaçōes. A cada usuário é atribuída uma cor de forma a identificar o autor das anotações. Estes sistemas seguem o conceito WYSIWIS (What You See Is IWhat I See). 
No próximo capítulo encontra-se um sucinto levantamento bibliográfico sobre estruturação e intercâmbio de documentos hipermidia. Uma ênfase será dada aos padrões SGML, HTML e RTF, que foram propostos para permitir que documentos hipermídia possam ser descritos apenas em termos de estrutura e conteúdo, e assim, processados em qualquer plataforma computacional.

objetivo do próximo capítulo consiste em apresentar ao leitor os pressupostos técnicos sobre esses padrões, que foram necessários para o desenvolvimento do mecanismo de importação e adaptação proposto por este trabalho, bem como para o enriquecimento do editor de nós terminais do tipo texto do SASHE, uma vez que ele passa a manipular não apenas texto plano (sem formatação), mas, sim, texto formatado segundo as regras estabelecidas pelo padrão RTF. 


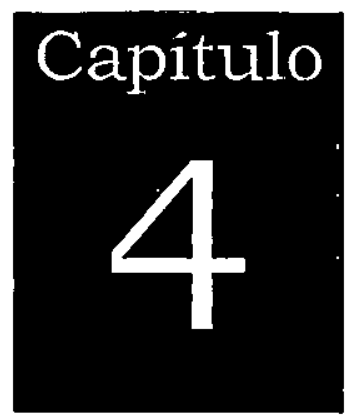

\section{Estruturação e intercâmbio de documentos hipermidia}

\section{1 - Considerações iniciais}

Da análise de um documento é possivel identificar sua estrutura. Um livro, por exemplo, possui um título, um índice e vários capitulos; cada capitulo, por sua vez, possui um título e uma ou mais seções. Essa estrutura pode variar significativamente entre tipos de documentos diferentes. Uma carta, por exemplo, não possui nenhum dos elementos citados para o livro. Isso levou alguns pesquisadores a procurar por um padrão de representação de documentos que pudesse representar todas as estruturas que se fizessem necessárias.

Dentro de um documento existem alguns outros elementos que também merecem atenção especial. Citações, palavras destacadas e palavras de outro idioma devem ser representadas de uma forma diferente para facilitar a compreensão do leitor.

A representação de documentos deve considerar, também, a necessidade da especificação de relaçōes intra e entre documentos. Exemplos destas relações são as referências bibliográficas, que levam ao documento original e palavras-chave que levam a documentos mais específicos. Quando as 
associações podem ser selecionadas interativamente pelo leitor, resultando na apresentação automática do conteúdo associado, os documentos são chamados de hiperdocumentos.

Por outro lado, o mercado de aplicações multimídia é, atualmente, composto por inúmeros fabricantes que utilizam tecnologia proprietária para a codificação e o armazenamento de seus documentos. No entanto, os sistemas de comunicação que interligam várias redes são constituídos por uma grande variedade de tecnologias que interoperam. Em sistemas heterogêneos como estes, a interoperabilidade somente é alcançada quando são utilizados padrões abertos. Desse modo, tornouse necessária a criação de padrões que permitam a reutilização de objetos multimídia em diferentes ambientes (intercâmbio), por diferentes aplicações.

Este capítulo apresenta alguns padrões internacionais utilizados para a representação e o intercâmbio de documentos, como é o caso do SGML (Standard Generalized Markup Language), do HTML (HyperText Markup Language) e do RTF (Rich Text Format), que são abordados nas seções 4.2, 4.3 e 4.4 , respectivamente.

\section{2 - SGML}

O padrão SGML foi proposto para permitit que documentos armazenados eletronicamente pudessem ser definidos conforme seu conteúdo e sua estrutura, independentemente de sua forma de apresentação (Brown, 1989).

Conseqüentemente, oferece flexibilidade para que possa ser definido um conjunto ilimitado de linguagens específicas, por exemplo, uma para memorandos, uma para artigos, uma para livros, entre outras.

Cada linguagem é formalizada em um D'TD (Document Type Definition), ou descritor, que estabelece: a) que tipos de elementos podem existir em um documento (por exemplo, um livro pode conter um título, capítulos, seções, subseções etc.); b) que atributos esses elementos podem ter (por exemplo, a data da última revisão); e c) como as instâncias desses elementos estão hierarquicamente relacionadas (por exemplo, um livro contém capitulos, os quais contêm seções, as quais podem conter subseções etc.).

A estrutura lógica de um documento SGML é descrita através de marcas padronizadas (markups), comumente chamadas de etiquetas. Essas marcas identificam o início e o final de cada objeto lógico, chamado elemento SGML, e permitem a especificação de seus atributos. 
A linguagem especificada em um DTD fornece apenas a estrutura lógica de um documento, não sendo fornecida nenhuma informação a respeito da semântica de apresentação do documento. Deste modo, para um livro, por exemplo, é dada a estrutura de seus capítulos e seções, mas aada é definido a respeito do formato de apresentação das páginas, colunas, ou qual a fonte será empregada para os caracteres. Por conseguinte, uma aplicação que processa um documento SGML é responsável por especificar como as instâncias dos elementos devem ser visualizadas no documento final. Isso é feito, normalmente, com a utilização de folhas-de-estilo (stylesbeets).

\subsection{1 - Elementos}

O objeto lógico mais simples em um documento SGML é o elemento, que é composto de três partes: start-tag, conteúdo e end-tag. A Figura 4.1 ilustra a anatomia de um elemento SGML.

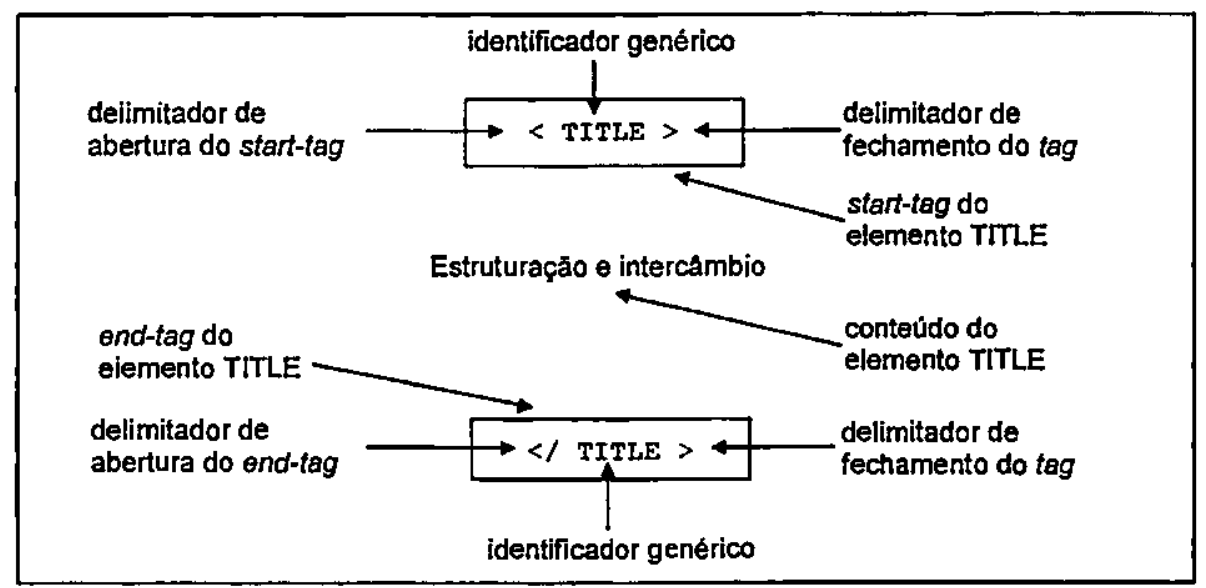

Figura 4.1 - Anatomia de um elemento SGML (Herwijnen, 1994)

As tags são utilizadas para definir o início e o fim de um elemento dentro do documento, delimitando um fragmento de texto que sofrerá algum tipo de formatação. O conteúdo identifica a natureza do elemento, que pode ser uma seqüência de caracteres ou um outro elemento.

A possibilidade de se criar elementos dentro de outro elemento, garante a estruturação hierárquica dos documentos SGML. A Figura 4.2 fornece, como exemplo, a estrutura hierárquica utilizada nos capítulos desta dissertação. 


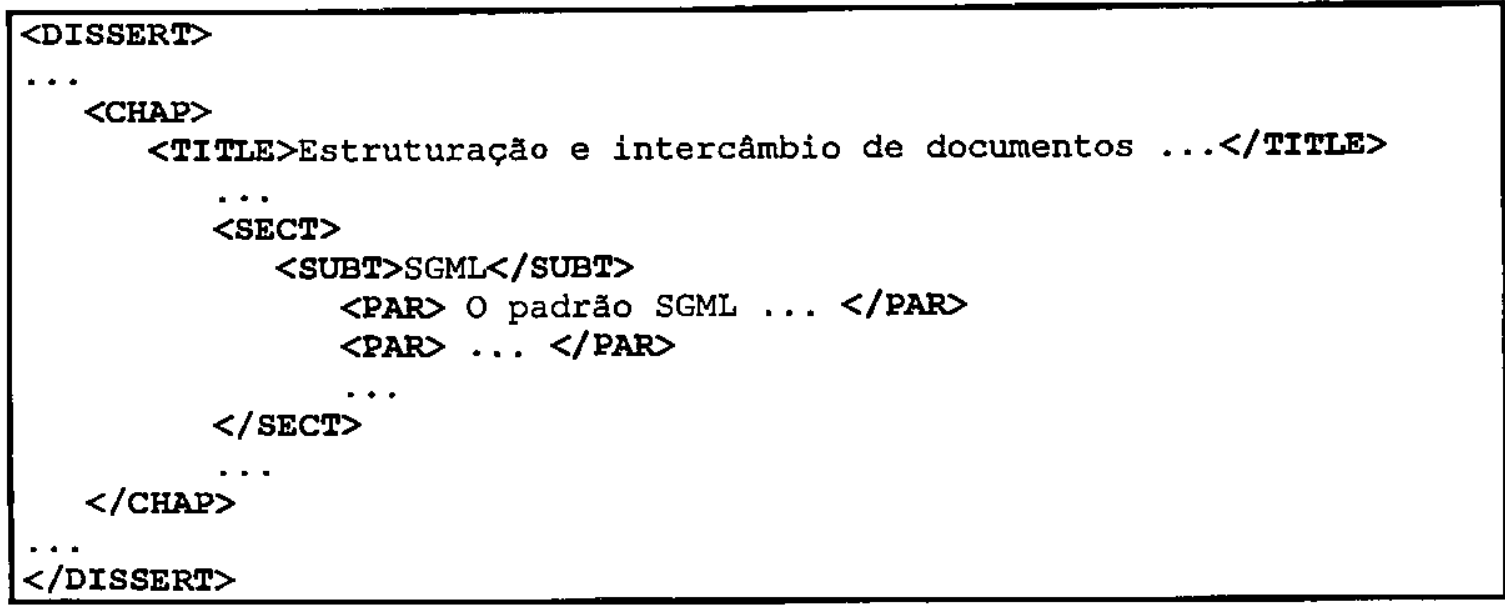

Figura 4.2 - Estrutura hierárquica dos capítulos desta dissertação

\subsection{2 - Atributos}

Um atributo é um qualificador que indica uma propriedade (de referência, de formatação, entre outras) de um determinado elemento. Por definição, um atributo é definido pelo par "nome" e "valor" presente na start-tag do elemento, logo após a declaração de seu nome. O valor do atributo deve estar sempre entre aspas, tal como:

$$
\text { <nome_elemento nome_atributo="valor_atributo"> }
$$

Logo, em sua forma mais completa, um start-tag de um elemento SGML pode consistir de um delimitador de início de start-tag, seguido de um identificador genérico, uma lista de atributos, e finalmente, finalizado por um delimitador de fechamento de tag.

\subsection{3 - Entidades}

Um documento SGML pode ter também referências a outras entidades (internas ou externas). Quando internas, normalmente se referem a um caractere especial não pertencente ao teclado ou um símbolo reservado de marcação. Quando externas, se referem a arquivos, documentos, imagens, entre outros.

No corpo de um documento, a referência a uma entidade é feita iniciando-se por " $\&$ ", seguido do nome da entidade e terminando-se com ";", como em "\&aacute;". Durante a elaboração do DTD, 
para definir que o texto "Standard Generalized Markup Language" substitui a entidade "SGML", faz-se o seguinte:

\section{<!ENTITY SGML "Standard Generalized Markup Language">}

Nesse caso, um fragmento de texto que estivesse na seguinte forma: "O padrão \&SGML; foi proposto para...", seria interpretado por um SGML parser exatamente como: "O padrão Standard Generalized Markup Language foi proposto para...".

\subsection{4 - SGML parser}

Para assegurar que as marcações de um documento estejam consistentes, livre de erros, e possam ser intexpretadas corretamente, todo sistema conformante deve conter um programa que reconheça markups SGML em seus documentos. Esse programa é chamado de SGML parser, e deve possuir mecanismos que chequem: a) se o DTD de um documento segue o padrão SGML; e b) se a instância do documento está de acordo com esse DTD.

Às vezes, um texto possui elementos que devem receber um tratamento diferenciado por parte do parser. Por exemplo, em um livro sobre SGML podem ocorrer vários exemplos com etiquetas que não devem ser processadas. Assim, durante o reconhecimento de um texto, um parser SGML deve dar tratamento diferenciado a fórmulas matemáticas, texto formatado e texto com marcação (Herwijnen, 1994).

\subsection{5 - Comentários}

O padrão SGML também permite que se adicione comentátios ao corpo do documento. Os comentátios iniciam-se com “<!--" e terminam com “-->”, não fazendo parte do conteúdo textual do documento. Os comentários podem ser incluidos em qualquer ponto do documento e podem conter quaisquer caracteres, à exceção da seqüência “....".

\section{3 - HTML}

O padrão HTML (HyperText Markup Language) é formalmente definido por um DTD SGML. Desse modo, a HTML determina a maneira pela qual um conjunto de elementos deve estar estruturado 
para compor um documento, bem como a definição de elos entre seus elementos e a inclusão de outras mídias no corpo de um documento.

A navegação em documentos HTML se faz através das operaçōes básicas definidas pela tecnologia de hipertextos: seleção livre de relacionamentos, complementada por operações de backtracking, bookmarking e controle de caminho percotrido (histórico da navegação) (Pimentel \& Hagui, 1996).

Atualmente, a grande maioria dos documentos disponibilizados na WWW é estruturada de acordo com o padrão HTML que impõe uma estrutura simples aos hiperdocumentos, sendo suportada por diferentes browsers e plataformas (Berners-Lee et al., 1994).

No entanto, a simplicidade do padrão HTML limita a estrutura de relacionamentos que pode ser associada aos hiperdocumentos. Entre essas limitações, de acordo com Rodrigues e Soares (1998), destacam-se:

- O modelo de dados com elos embutidos nos nós (páginas HTML) não permite a separação dos dados sendo referenciados e de suas referências (byperlinkss), dificultando a reutilização dos dados sem a herança obrigatória das relações;

- Só podem ser estabelecidos elos do tipo "ponto-a-ponto" unidirecionais, sempre expressando uma relação do tipo "go to", o que impossibilita saber que elos fazem referência a uma determinada página.

Pelo fato da estrutura estabelecida pelo padrão HTML ser muito simples, um hiperdocumento construido com HTML não pode apresentar, por si só, uma estruturação elaborada. Assim, as markupss são colocadas livremente na composição do hiperdocumento, conforme ilustra o trecho de codificação HTML da Figura 4.3, e a sua visualização na Figura 4.4. 


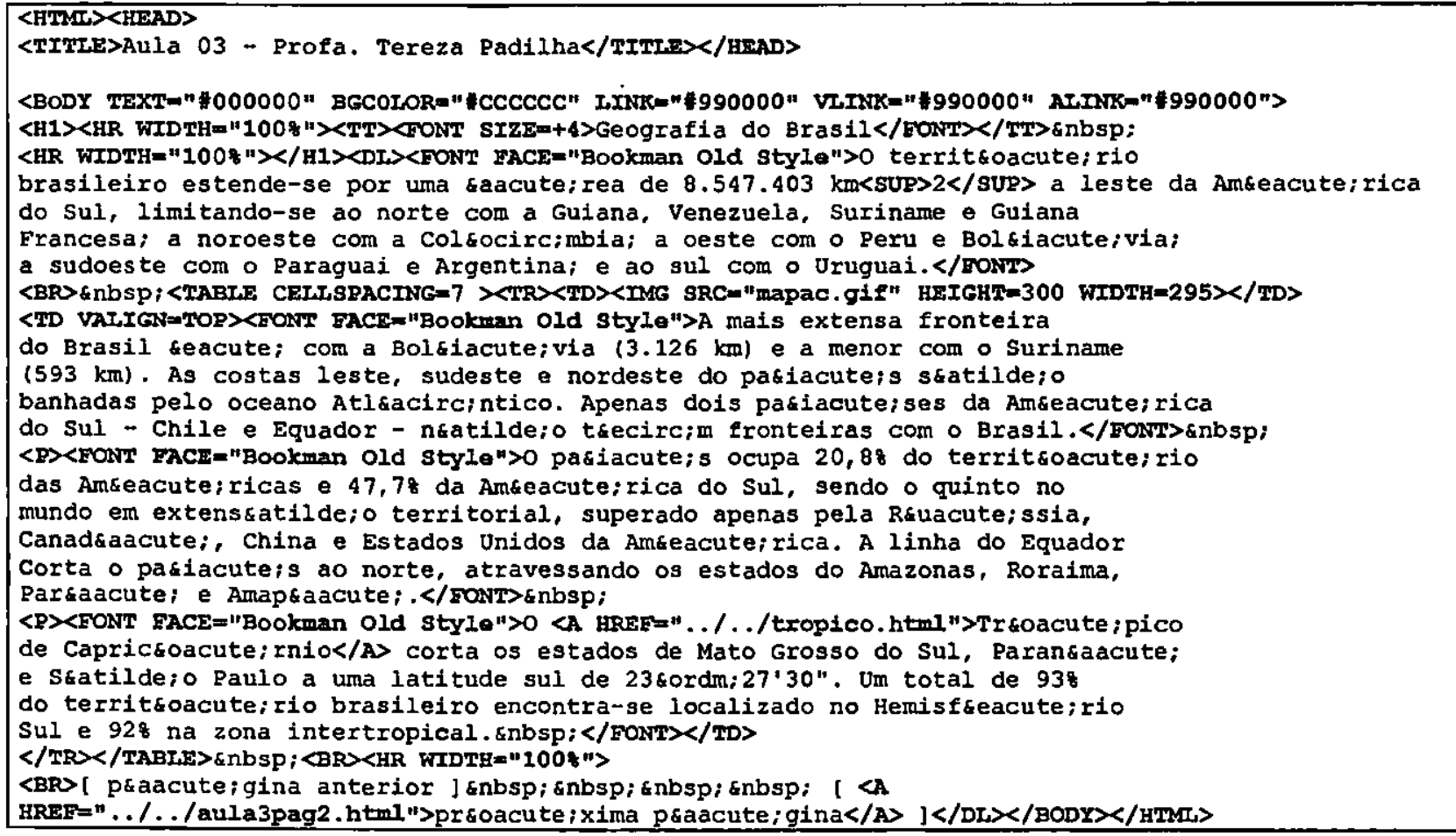

Figura 4.3 - Documento HTML simples

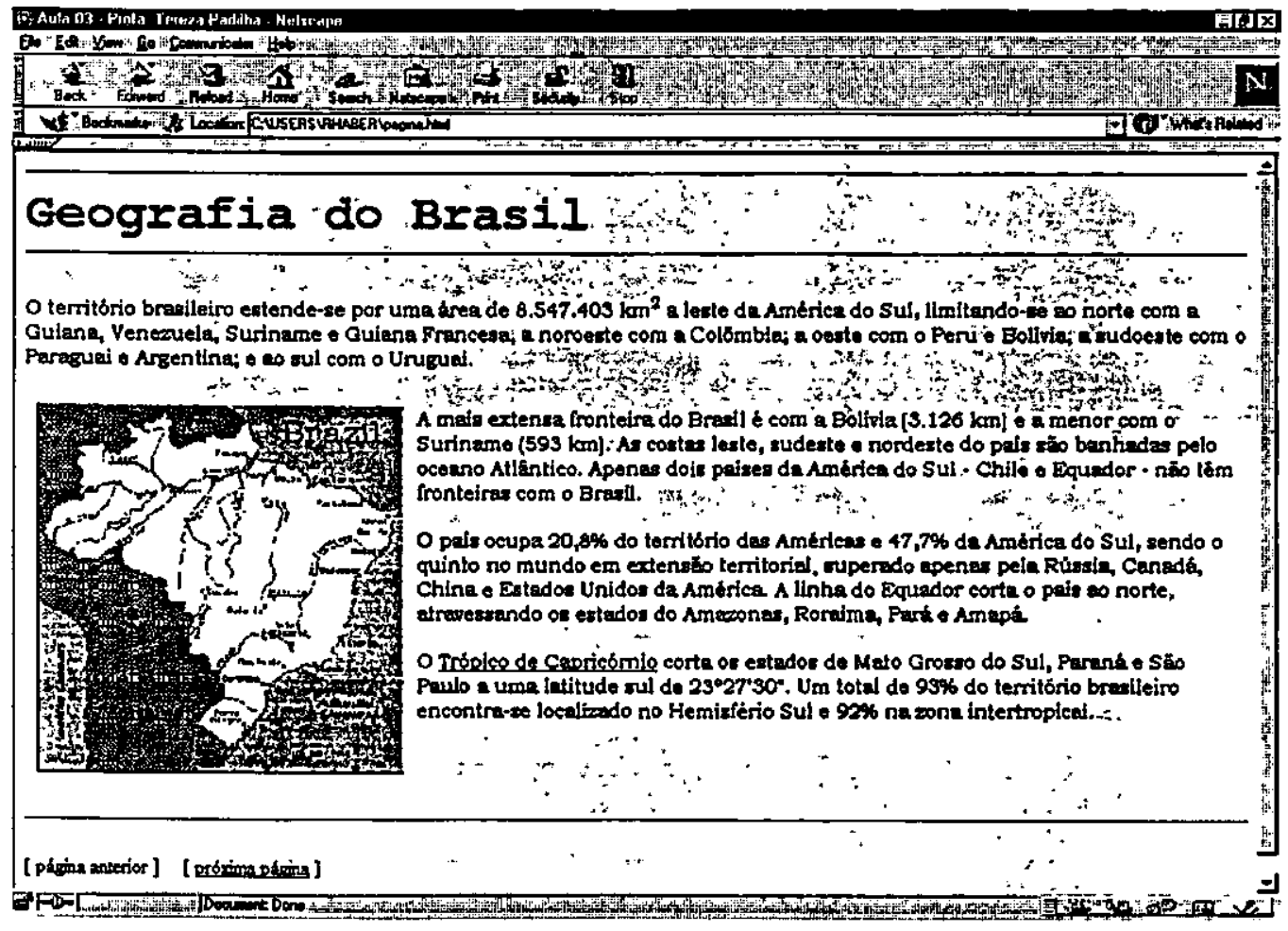

Figura 4.4 - Visualização do código HTML da Figura 4.3 
Esse hiperdocumento é bastante simples, e apresenta a definição de elementos estruturais (HEAD e BODY) lado a lado com elementos associados à forma de apresentação (TABLE, IMG, H1, HR, DI, FONT, SUP e BR).

O elemento <HEAD> contém informações que não fazem parte do conteúdo textual do documento a ser exibido pelo browser. Vários elementos podem ser inseridos nessa seção, entre eles destacam-se: o elemento <TITLE> que define o título do documento, identificando a janela na qual o documento está sendo exibido e o elemento $<$ AUT HOR $>$ que identifica o autor do documento.

O corpo do documento, ou seja, o conteúdo que sexá exibido pelo browser (texto, imagens, tabelas, listas, vídeos etc.) está contido no elemento <BODY>.

\subsection{1 - Etiquetas}

Quando um browser apresenta uma página $W e b$, ele carrega o arquivo que contém a página e procura por símbolos especiais denominados etiquetas (markups), que nada mais são do que os comandos de formatação da linguagem.

As etiquetas baseiam-se na inserção de palavtas reservadas entre um par de chaves menor $(<)$ e maior ( $>$ ), delimitando um bloco do documento que sofrerá algum tipo de formatação. A maioria das etiquetas tem sua correspondente de fechamento, tal como: <etiqueta> .. </etiqueta>.

No entanto, algumas etiquetas são "vazias", isto é, não possuem uma etiqueta correspondente para fechamento do elemento. Destacam-se nessa classe de etiquetas: os separadores (<BR> e <HR $>$ ) e os itens de lista $(<\mathrm{LI}>)$.

\subsection{2 - Estabelecimento de relacionamentos}

Um documento HTML é constituído de fragmentos de texto, tabelas e imagens, sendo muito parecido com os documentos produzidos por um editor de textos. $O$ que lhe diferencia de um documento comum é a possibilidade de se associar uma palavra, um trecho de texto ou uma imagem com outras partes do mesmo documento ou de outros documentos. Com a ativação desses relacionamentos por um dispositivo apontador, o browser encarrega-se de desviar a exibição, correlacionando o contexto atual com o assunto apontado por essa ligaçāo.

Utilizando-se somente HTML podem ser estabelecidos três tipos de links. 
- Externos - de uma região de um hiperdocumento para outro hiperdocumento;

- Internos - de uma região de um hiperdocumento para outra tegião do mesmo hiperdocumento;

- Bidirecionais - de uma região de um hiperdocumento para uma região de outro hiperdocumento.

No protótipo de ambiente de navegação do SASHE, conforme será apresentado nos capítulos 5 e 6, os nós de informação do tipo texto são visualizados como documentos HTML. No entanto, somente podem ser definidos relacionamentos externos. Todavia, é possível a definição de elos do tipo "um-para-muitos". Essas características foram herdadas das abstrações do Modelo de Contextos Aninhados.

\section{4 - RTF}

O padrão RTF (Rich Text Format) foi proposto pela Microsoft como um formato aberto para intercâmbio de documentos entre o Microsoft Word e outros pacotes de processadores de texto, sendo suportado pelo Lotus Notes, WordPerfect, Interleaf e muitos outros pacotes baseados em UNIX, Macintosh, Next e plataformas PC.

Basicamente, um arquivo RTF consiste de texto não-formatado, palavras-de-controle (control words), símbolos-de-controle (control symbols) e informaçöes gerais do documento (palavras-chave, data e $\mid$ hora de criação, entre outras). Essas informações são adicionadas ao cabeçalho do arquivo e não fazem parte do conteúdo textual do documento, ou seja, não são exibidas no modo de edição.

\subsection{1 - Control words}

Uma palavra-de-controle é uma "marcação" utilizada para delimitar um bloco do documento que sofrerá algum tipo de formatação, ou para armazenar informações que serão utilizadas durante o processamento (edição ou impressão) do documento (como por exemplo, a fonte default a ser empregada para os caracteres).

Uma palavra-de-controle, ou markup RTF, não pode ultrapassar 32 caracteres, e deve ser escrita da seguinte forma: uma backslash, seguida de uma cadeia de caracteres, sendo finalizada por um delimitador, tal como:

\cadeia-de-caracteres [delimitador] 
A cadeia de caracteres contém um identificador genérico (palavra reservada do padrão RTF) e deve ser escrita apenas com caracteres alfabéticos minúsculos, ou seja, diferentemente dos padrões SGML e HTML, os comandos do padrão RTF são sensíveis ao contexto.

O delimitador, por sua vez, demarca o fim de uma palavra-de-controle e pode ser representado por:

- Um caractere backslash. Nesse caso, o delimitador da palavra-de-controle passar a ser o início de

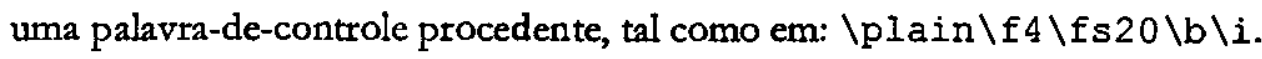

- Um caractere espaço. Nesse caso, o espaço faz parte da palavra-de-controle, e, por conseguinte, pertence ao código do arquivo RTF.

- Um caracțere numérico ou um hífen (-) seguido de um caractere numérico.

- Um caractere alfabético que não pertence ao código.

Tal como em outros padrões de representação, o atributo de uma determinada palavra-de-controle possui dois estados: ativo ou inativo. Assim, quando o delimitador for representado pelo caractere zero (0), o atributo indicado pela palavra-de-controle torna-se inativo. Como exemplo, $\backslash \mathrm{b}$ torna a propriedade negrito ativa, enquanto $\backslash \mathrm{b} 0$ torna a mesma propriedade inativa.

\subsection{2 - Control symbols}

Um símbolo-de-controle pode ser definido como uma palavra-de-controle "vazia", ou seja, sem uma correspondente de fechamento. Por definição, um símbolo-de-controle consiste de uma backslash, seguida por um único caractere não-alfanumérico.

Como exemplo, o caractere " $\backslash "$ possui significado especial durante o processamento de um arquivo RTF. Assim, para utilizar esse caractere como texto, deve-se utilizar o seguinte símbolo-de-controle: “\".

\subsection{3 - RTF Reader}

Um programa que reconhece e processa palavras-de-controle e símbolos-de-controle, transformando um arquivo RTF em um documento formatado, por definição, é chamado de reader. Logo, uma ferramenta dessa natureza deve ser capaz de: a) separar as palavras-de-controle e os 
símbolos-de-controle do conteúdo textual de um arquivo RTF; e b) aplicar ao conteúdo textual as propriedades e ações sugeridas pelas palavras-de-controle e símbolos-de-controle.

Na prática, um RTF reader processa cada caractere que ele lê, da seguinte maneira:

- Se o caractere é um "abre chaves" ( 1 ), o reader armazena as propriedades de formatação (estado) subseqüentes em uma pilha. Se o caractere é um "fecha chaves" (\}), o reader retira o estado da pilha.

- Se o caractere é um backslash ( ), o reader coleta as palavras-de-controle ou símbolos-de-controle e seus parâmetros. Nesse momento é feita uma busca em uma tabela interna que indica uma ação a ser executada. Essa ação pode ser uma substituição no caso de um símbolo-de-controle (como por exemplo, em um arquivo RTF a seqüência " \' el" representa o caractere acentuado “á”), ou uma alteração nas propriedades de formatação do texto.

- Se o caractere é qualquer outro a não ser "abte chaves", "fecha chaves" ou backslash, o reader assume que esse caractere pertence ao conteúdo textual do documento, e o escreve em sua posição de destino, utilizando as propriedades de formatação que estão no topo da pilha.

Tal mecanismo foi implementado na função de conversão de documentos RTF para documentos HTML, que é utilizada no processo de visualização de nós terminais do tipo texto nos módulos de autoria e navegação do protótipo SASHE versão 2.0, conforme será apresentado no capítulo 6 .

\section{5 - Considerações finais do capítulo}

Os sistemas hipermídia estão se tornando cada vez mais importantes nos ambientes que envolvem usuários e computadores. Contudo, muitos sistemas hipermidia têm sido desenvolvidos como aplicações autocontidas, o que dificulta o reuso não só dos sistemas em si, como também, dos hiperdocumentos por eles criados e processados (Soares et al., 1995b). Esse quadro deve ser) revertido para que hiperdocumentos desenvolvidos em plataformas heterogêneas façam uso de objetos estruturados; estruturação essa que possibilite a teutilização dos objetos.

Desse modo, a comunidade científica, reconhecendo a importância de viabilizat a reutilização de hiperdocumentos, têm dirigido esforços no desenvolvimento de padrões tais como SGML, HTML, RTF, entre outros. 
A disseminação da Internet, por sua vez, abriu nova perspectiva para a educação, principalmente devido ao seu potencial de comunicação e acesso à informação. No entanto, o modelo de dados embutido nos nós (páginas HTML) apresenta uma estrutura "rasa", ou não-hierátquica, de relacionamentos, que faz desses documentos meros reservatótios de informações, carentes de uma estrutura didaticamente ordenada.

Dessa forma, existem algumas diferenças entre os hiperdocumentos criados no ambiente SASHE e os tradicionais HTML, que apontam para as seguintes vantagens do primeiro em relação aos últimos: a) a contextualização e o aninhamento de nós, que auxiliam o autor a definir roteiros flexíveis; b) uma interface que oferece subsídios para o controle de processos cognitivos do aprendiz durante a sua navegação; e c) a possibilidade de navegação em brovvers que fornecem uma visão estrutural total ou parcial dos hiperdocumentos.

Torna-se interessante, então, a definição de mecanismos/ferramentas que permitam a importação e adaptação de documentos HTML para a plataforma interna do SASHE, pois seu ambiente de autoria permite que o autor organize os nós de informação do hiperdocumento de forma hierárquica, uma vez que o aninhamento de nós não é possível em HTML.

No próximo capítulo será apresentado o ambiente de autoria e navegação SASHE versão 2.0, que implementa as características de aninhamento e qualificação de seus elementos de informação, bem como as características, quanto ao controle do usuário (aprendiz), discutidas no segundo capítulo. 


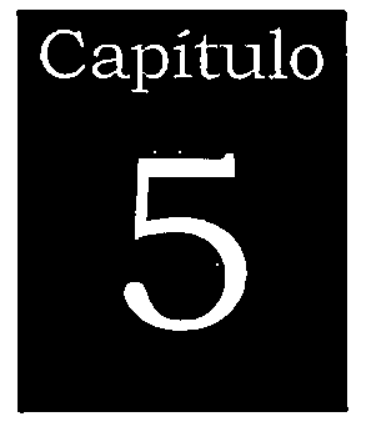

\section{SASHE -}

\section{Sistema de Autoria e Suporte Hipermidia para Ensino}

\section{1 - Considerações iniciais}

O Sistema de Autoria e Suporte Hipermídia para Ensino (SASHE) (Nunes et al., 1997; Santos, 1997; Santos et al., 1997) é um ambiente de autoria e navegação de hiperdocumentos para aplicações de ensino desenvolvido no Instituto de Ciências Matemáticas e de Computação (ICMC). O protótipo do SASHE, acrescido de novas funcionalidades, foi denominado SASHE versão 2.0.

O Modelo de Contextos Aninhados, modelo conceitual hipermidia empregado na estruturação dos objetos que compõem os hiperdocumentos desenvolvidos pelo SASHE, é apresentado na seção 5.2.

A seção 5.3 apresenta a nova arquitetura desse protótipo. Os recursos de autoria disponiveis na versão anterior e mantidas na atual, mais as novas funcionalidades de autoria propostas por este trabalho e por Pansanato (1999), são descritas na seção 5.4. Os recursos de navegação são brevemente comentados na seção 5.5 . 
Finalmente, na seção 5.6 encontra-se um framewvork comparativo entre os ambientes de criação, estruturação e distribuição de material didático apresentados no capítulo 3, e os ambientes de autoria e navegação do SASHE.

\section{2 - MCA - Modelo de Contextos Aninhados}

O MCA (Modelo de Contextos Aninhados) (Casanova et al., 1991; Soares et al., 1994, 1995a) é um modelo conceitual para a definição, apresentação e navegação de hiperdocumentos. Nesta seção, uma ênfase é dada para as estruturas de dados do MCA básico e seu modelo de apresentação. Uma formalização maior do modelo e detalhes sobre o controle de versões pode ser encontrada em (Casanova et al., 1991).

\subsection{1 - Definições do modelo básico}

A definição de hiperdocumentos no MCA é baseada nos conceitos usuais de nós e elos. O modelo distingue duas classes básicas de nós: os nós terminais e os nós de composição, sendo esses últimos o ponto central do modelo. A Figura 5.1 ilustra a hierarquia de classes do MCA.

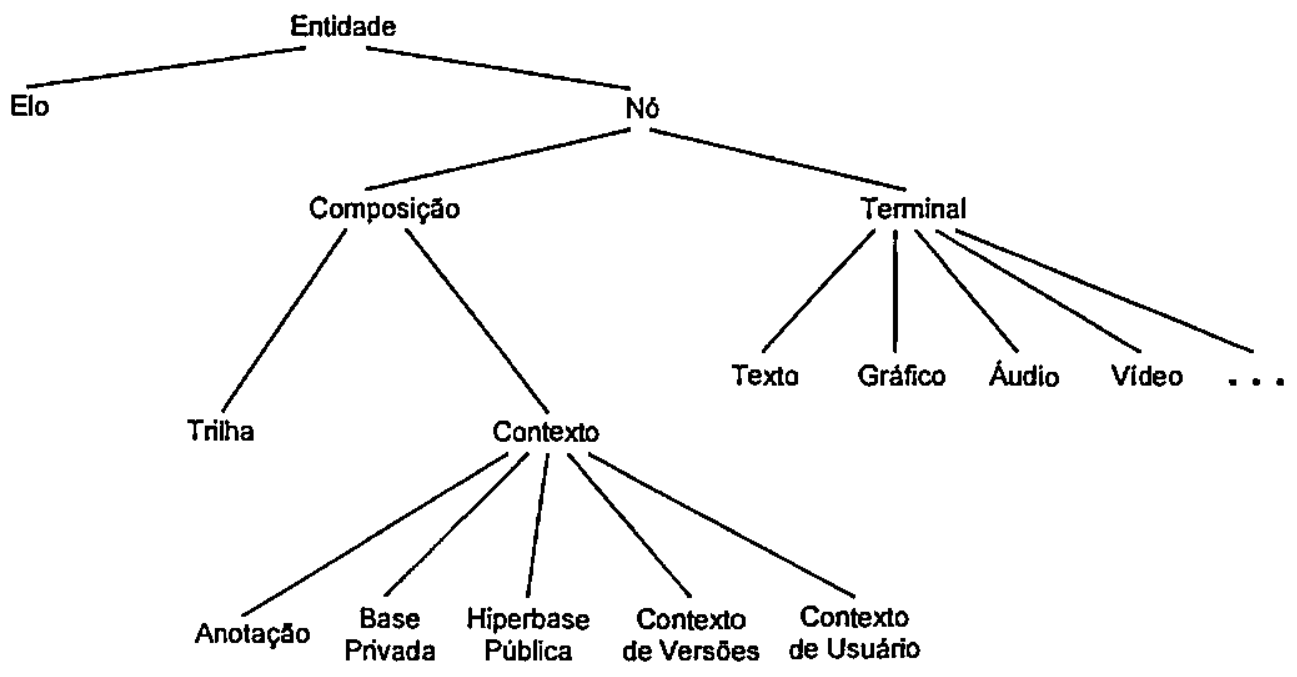

Figura 5.1 - Hierarquia de classes do MCA (Soares et al., 1994)

Uma entidade é um objeto que tem como atributos um identificador único, uma lista de controle de acesso e um descritor de entidade. $O$ identificador único tem o significado usual. Para cada atributo da entidade, a lista de controle de acesso tem uma entrada que associa um usuáno ou um grupo de 
usuátios aos seus direitos de acesso ao atributo. O descritor de entidade contém uma especificação (informação) que determina como a entidade deve ser apresentada ao usuário.

Um nó é uma entidade que tem como atributos adicionais um conteúdo e um conjunto de âncotas. Cada elemento do conjunto de âncoras é chamado âncora do nó, e é um objeto que tem como atributos um identificador, uma região e um conjunto de pares condição/ação. A exata definição do conteúdo do nó e da região ancorada depende da classe do nó.

Intuitivamente, os dados contidos em um nó terminal possuem uma estrutura interna dependente da aplicação, constituindo-se nos nós hipermídia tradicionais. Por conseguinte, o modelo permite a especialização da classe de nós terminais em outras classes (texto, gráfico, áudio, vídeo, entre outras).

Um nó de composição agrupa entidades, chamadas de componentes, incluindo outros nós de composição. Os componentes não formam necessariamente um conjunto, podendo uma entidade ser incluída mais de uma vez em um nó de composição. A classe de nós de composição pode ser especializada em duas outras classes: nós de contexto e nós do tipo trilha.

Um nó de contexto é utilizado para agrupar um conjunto que pode ser formado por elos, trilhas, nós terminais e de contexto, recursivamente. A classe de nós de contexto pode ser especializada em outras classes: nós de anotação, contexto de versões, base privada, hiperbase pública e contexto de usuário.

Um nó de contexto de usuário é utilizado para agrupar um conjunto de elos, nós terminais e de contexto de usuário. Como todo nó de composição, os nós de contexto de usuário podem ser aninhados em qualquer profundidade, permitindo organizar, de maneira hierárquica ou não, conjuntos de nós.

Um elo é uma entidade com dois atributos especiais: o conjunto de extremidades origem e o conjunto de extremidades destino. Por definição, além de relacionamentos do tipo "um-para-um", o MCA permite relacionamentos do tipo "um-para-muitos" e "muitos-para-muitos", que são necessátios para suportar aplicações em que, por exemplo, a seleção de um elo pode levar à apresentação simultânea de vários nós. Os elos são sempre unidirecionais, embora possam ser seguidos em ambas as direçŏes.

Os nós do tipo trilha são especializações de nós de composição que contém uma lista ordenada de nós, incluindo nós do tipo trilha, sendo que um nó pode estar na lista em mais de uma posição. Essa classe de nós é empregada no desenvolvimento de mecanismos que ofereçam suporte à navegação. 
Uma hiperbase é qualquer conjunto $H$ de nós tal que, para qualquer nó $N$ pertencente a $H$, se $N$ é um nó de composição, então todos os nós contidos em $\mathrm{N}$ também pertencem a $H$.

\subsection{2 - Modelo de apresentạ̧ão}

O MCA básico trata um hiperdocumento como estruturas de dados essencialmente passivas. $O$ modelo de apresentação do MCA trata dos aspectos de edição, apresentação e navegação através da estrutura dos hiperdocumentos.

$\mathrm{Em}_{\mathrm{m}}$ geral, os descritores mencionados anteriormente definem métodos para exibir ou editar entidades. $O$ modelo de apresentação do MCA fornece métodos específicos somente pata editar atributos do sistema, e para navegar e editar o conteúdo de nós de contex to.

$O$ modelo de apresentação do MCA oferece mecanismos genéricos de navegação. $O$ sistema HyperProp (Soares et al., 1995b), uma implementação de sistema hipermídia que utiliza o MCA como modelo conceitual, além de possuir primitivas para definir formas específicas de navegação, suporta esses mecanismos.

Os mecanismos de navegação oferecidos pelo modelo são: navegação por elos, idéia essencial de hipermídia; navegação por consulta, que permite ao usuário atingir um nó específico descrevendo propriedades que o nó satisfaz; navegação em profundidade (perspectiva), que é a ação de seguir o aninhamento de nós de composição, movendo-se para cima e para baixo na hierarquia de composições; navegação através de browsers, que possibilita uma visão gráfica do hiperdocumento (ou de partes dele); e navegação através de trilhas, que permite ao usuátio seguir trilhas preestabelecidas ou definidas como defauli no hiperdocumento.

\section{3 - Arquitetura do SASHE}

A Figura 5.2 apresenta a arquitetura em camadas do SASHE versão 2.0, com os novos módulos desenvolvidos para auxiliar a autoria: Modelagem e Importação. Esses dois módulos mais o módùlo de Edição, que engloba os recursos de autoria existentes na versão anterior, compõem a camada de Autoria. 


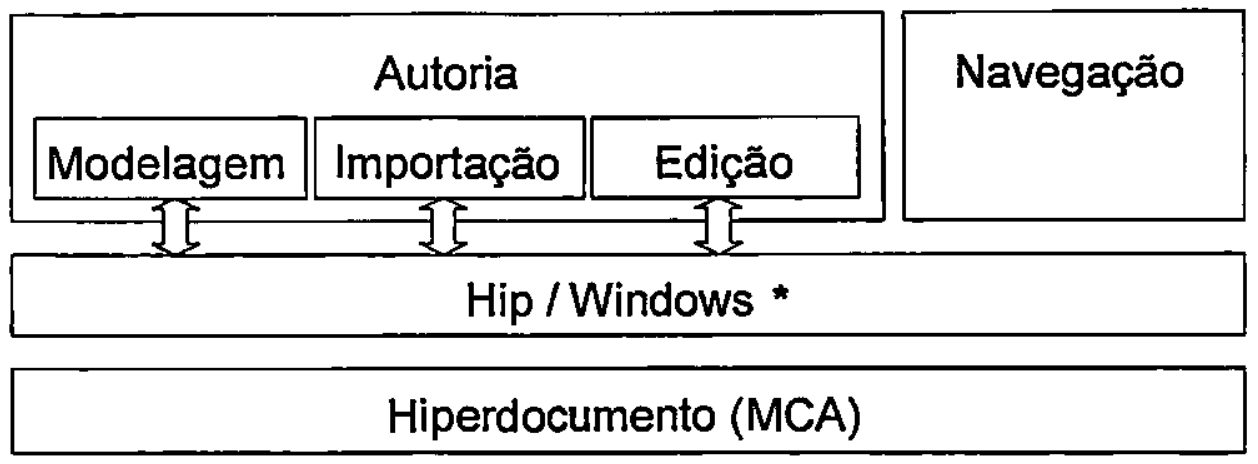

Figura 5.2 - Arquitetura geral do SASHE versão 2.0

As camadas de Autoria e Navegação utilizam-se das funções da camada Hip/Windows", que é uma extensão do ambiente HIP/Windows (Nunes et al., 1996). As setas da figura indicam que os módulos (Modelagem, Importação e Edição) utilizam diretamente as funções da camada Hip/Windows*, não existindo nenhum módulo (ou interface) intermediário. Essa camada é composta por funçōes que manipulam uma hiperbase MCA, que consiste de um hiperdocumento estruturado segundo o Modelo de Contextos Aninhados.

\section{4 - Módulo de Autoria}

Nesse módulo, o autor pode criar hiperdocumentos, desde os mais simples até os mais complexos, com vários níveis de aninhamento. No entanto, conforme discutido anteriormente, a qualidade da navegação encontrada pelo aprendiz está diretamente relacionada à estruturação organizacional proposta pelo autor (Ginige et al., 1995).

O módulo de Edição permite a construção de hiperdocumentos estruturados de acordo com as definições do MCA, utilizando apenas os conceitos de nó terminal (texto, gráfico, áudio e vídeo), nó de composição (trilha, contexto de usuátio e hiperbase pública), âncora e elo.

A interface do módulo de Edição utiliza o termo "Informação" para referir-se a um nó terminal devido a sua associação com um conteúdo (fragmento de informação) armazenado segundo uma determinada mídia. As informações (nós terminais) são classificadas quanto à sua função didática (motivação, introdução, definição, exemplo, exercícios, tesumo, bibliografia e ajuda), dificuldade (baixa, regular e alta) e palavras-chave relacionadas ao conteúdo. Esses atributos, conforme mencionado anteriormente, são utilizados pelas estratégias tutoriais durante a navegação. 
Os nós de contexto de usuário são utilizados para estruturar o hiperdocumento (hiperbase pública), sendo denominados apenas de "Contexto" pela interface do módulo de Edição. Um contexto representa um espaço de informação e pode conter outros contextos (recursivamente aninhados). Essa característica permite a construção de hiperdocumentos hierárquicos, partindo de contextos com informações mais gerais para contextos com informações mais específicas.

Durante a edição, quando o hiperdocumento começa a ter uma estrutura mais complexa, são necessárias novas formas de visualização, que procurem facilitar o trabalho de autoria. O SASHE oferece, além do navegador tradicional, o Browser Estrutural e o Browser Gráfico, que são recursos do ambiente que permitem ao usuário (autor/aprendiz) visualizar a estrutura de um hiperdocumento ou parte dela. O Browser Gráfico, ilustrado pela Figura 5.3,. encontra-se em fase de transposição da versão anterior.

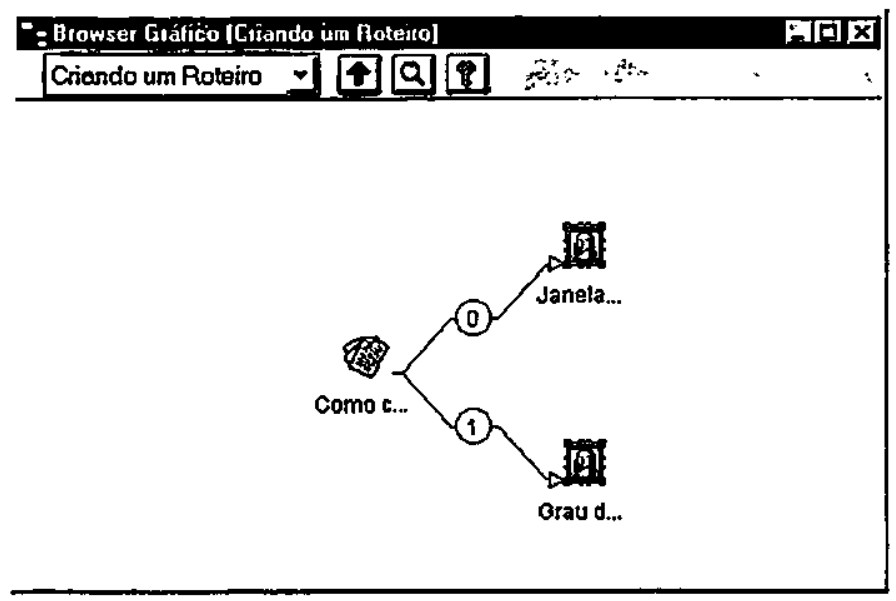

Figura 5.3 - Interface do Browser Gráfico (Nunes et al., 1997)

A diferença fundamental entre eles, de acordo com Nunes et al. (1997), é que, enquanto o Browser Estrutural apresenta a estrutura hierárquica dos nós de contexto e de informação em um listbox, o Browser Gráfico apresenta a mesma estrutuma como um grafo, dando uma medida de contexto e espaço, ou seja, destacando o vértice (âncora) selecionado pelo usuário e mostrando todos os elos que chegam nele ou saem dele.

A Figura 5.4 ilustra um pequeno exemplo de hiperdocumento através do Brovser Estrutural. Pode-se observar a estrutura hierárquica através dos contextos "Matéria", "Estados físicos da matéria", "Sólido", "Líquido"; "Gasoso" e "Água no estado gasoso". 


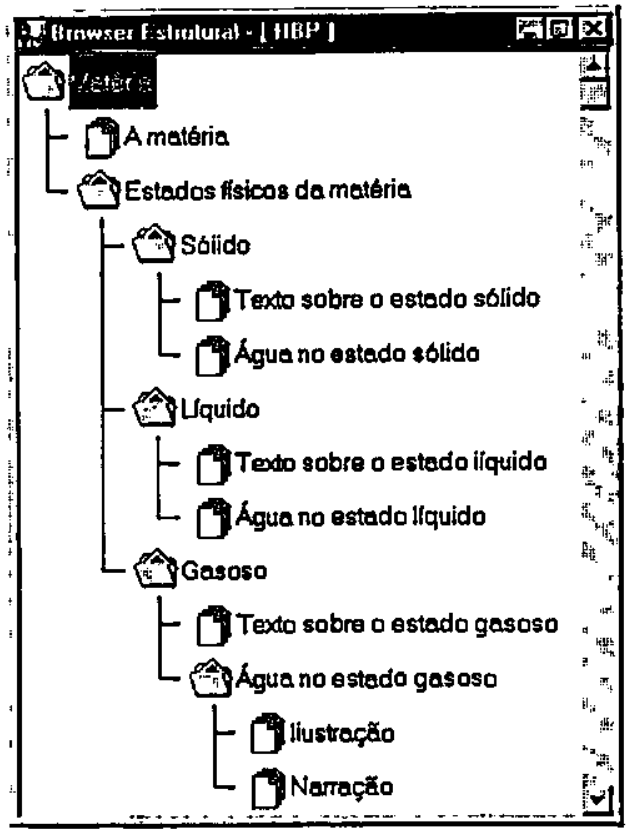

Figura 5.4 - Exemplo de um hiperdocumento estruturado

\subsection{1 - Criạ̧ão de nós, âncoras e elos}

A criação de um nó de contexto ou de informação é realizada através da janela ilustrada pela Figura 5.5. Quando se deseja inserir um nó do tipo contexto em um hiperdocumento, o único atributo habilitado é o campo "Nome", que determina o assunto implicado pelo contexto.

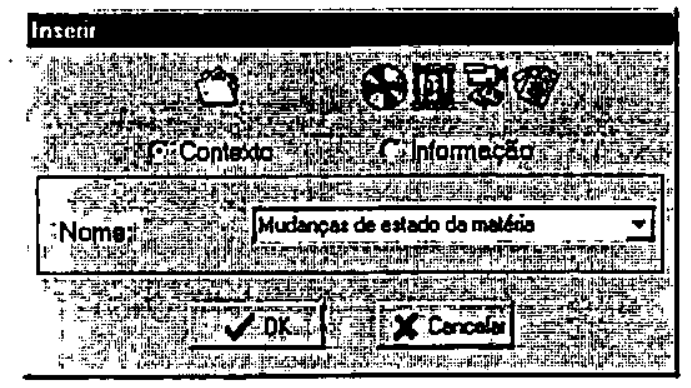

Figura 5.5 - Interface para criação de nós do tipo contexto

Porém, quando se deseja inserir uma informação (nó terminal) em um contexto do hiperdocumento, a janela apresentada na Figura 5.5 se modifica e todos os atributos são habilitados, conforme ilustra a Figura 5.6. Os atributos desse tipo de nó determinam, em grande parte, o comportamento das funções tutoriais (função didática, dificuldade e palavras-chave) e, portanto, é necessário que todos os seus atributos sejam atentamente preenchidos. 


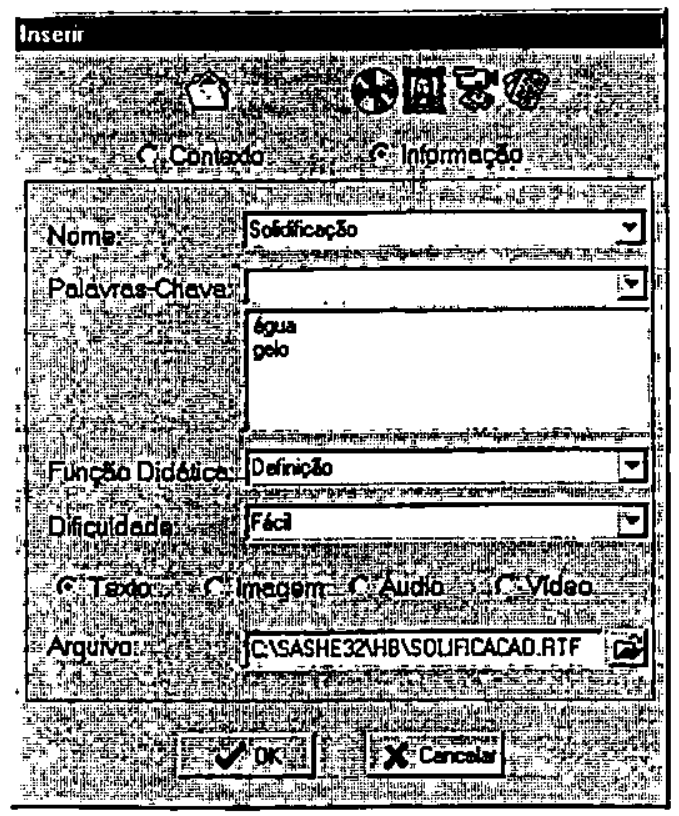

Figura 5.6 - Interface para criação de nós de informaçāo (terminais)

Nesta fase do projeto, para cada elemento de informação (nós terminais e de contexto) está associada uma âncora default, chamada lambda, que define uma ancoragem no limite do nó, ou seja, no nó como um todo. No entanto, apenas podem ser estabelecidos relacionamentos/ligações de um nó de informação do tipo texto para qualquer outro tipo de nó.

Assim, as âncoras são criadas através da edição do conteúdo dos nós de informação do tipo texto, conforme ilustra a Figura 5.7. Observa-se que esse editor não segue o princípio WYSIWYG, pois quando uma imagem é inserida no corpo de um documento, uma tag (etiqueta) HTML é inserida em seu lugar.

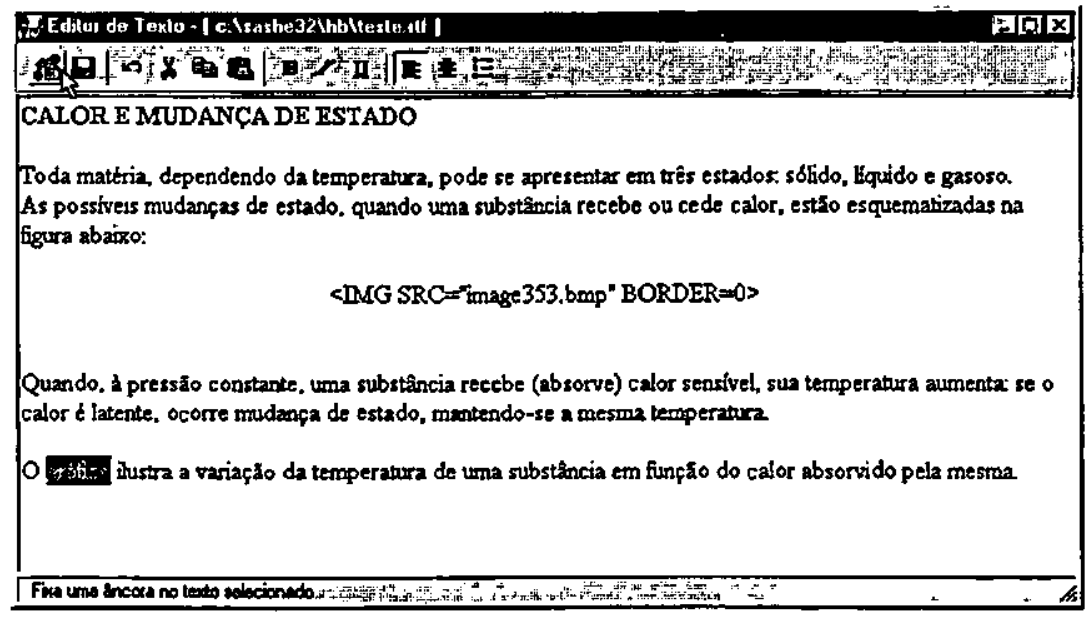

Figum 5.7 - Áncora sendo criada em um nó de informação do tipo texto 
No SASHE os elos são utilizados para conectar informações que mantêm alguma relação entre sí. Um elo pode conectar um nó de informação a outto nó de informação ou a um contexto. A criação/edição de elos é ilustrada pela Figura 5.8. Nesse caso, o elo inserido conecta um nó de informação a um contexto.

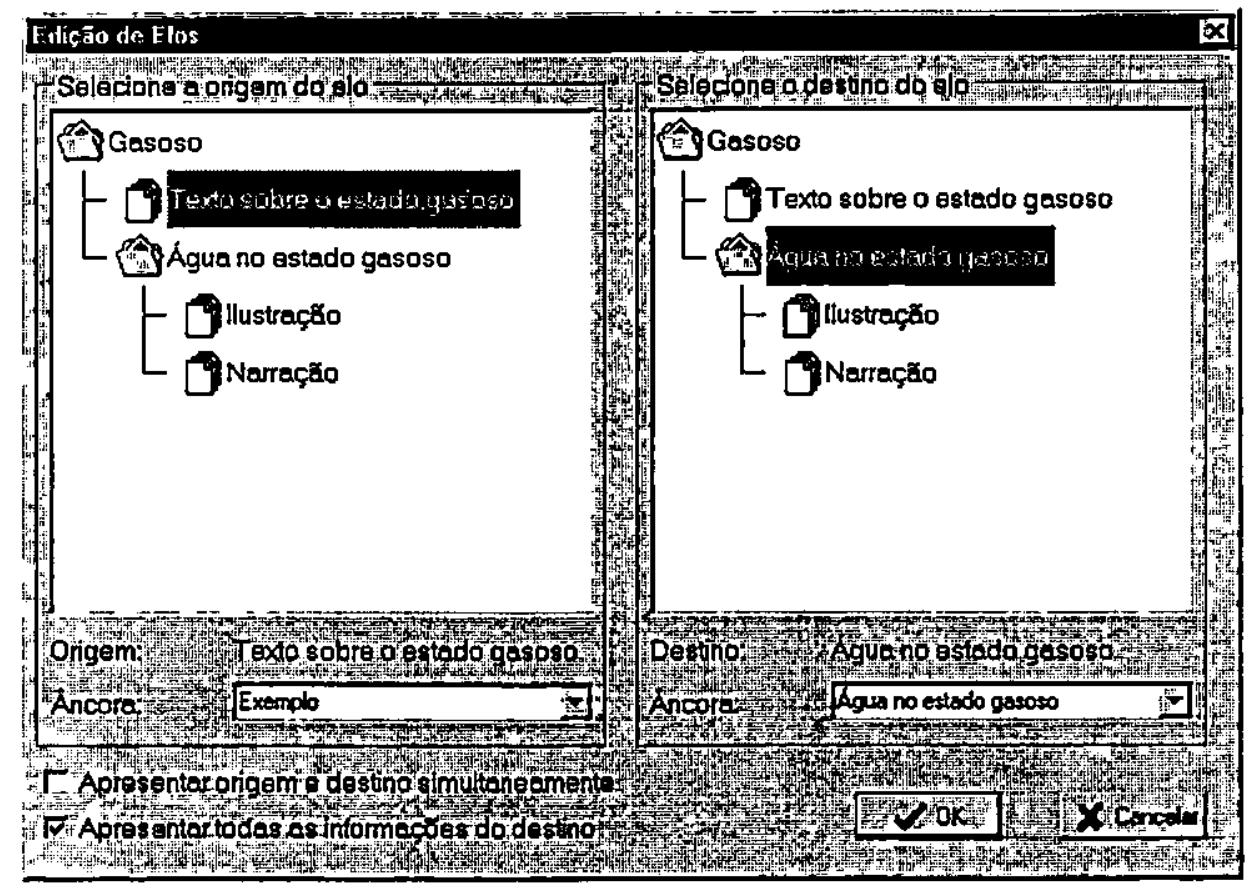

Figura 5.8 - Interface de criação/edição de elos

Para o estabelecimento de um novo elo, deve-se: 1) selecionar a origem e o destino do elo (pressionando o botão esquerdo do mouse sobre os nós desejados); 2) preencher a lista de possiveis âncoras que estão contidas nos respectivos nós (pressionando o botão direito do mouse sobre os mesmos); 3) configurar o modo de apresentação, selecionando as opções (checkbox) no extremo inferior esquerdo da janela; e 4) confirmar a criação acionando o botão "OK".

“Apresentar origem e destino simultaneamente" indica se o nó destino do elo deve ser apresentado simultaneamente ao nó origem. Muitas vezes é interessante manter aberta a janela que contém a âncora do elo enquanto que seu destino é apresentado. Por exemplo, se o elo leva à execução de um áudio e, depois disso, o aprendiz volta à leitura na posição de origem do elo (âncora original).

"Apresentar todas as informações do destino" indica se na apresentação de um nó contexto, destino do elo, devem ser mostrados todos os seus nós terminais ou deve ser ativado o Browser Gráfico. Assim, há duas possibilidades de visualização do nó de contexto destino. A primeira é abrir todos os 
nós terminais pertencentes ao.contexto. Isto é útil quando os nós pertencentes ao contexto são complementares, ou seja, juntos compõem uma única unidade de informação. Por exemplo, um nó texto e um nó áudio (com a narração do texto) formando um único contexto. A segunda possibilidade permite apresentar todos os nós do contexto através de um grafo. Este seria o caso default, uma vez que a abertura simultânea de vários nós terminais pode causar problemas quanto à utilização de recursos multimidia (se houver mais de um áudio ou mais de um vídeo, por exemplo).

\subsection{2 - Autoria de roteiros}

Depois da autoria da estrutura, o autor pode definir um ou mais roteiros de navegação através do hiperdocumento. Um roteiro (nó de composição do tipo trilha do MCA) é definido pela seqüência de informações e contextos que serão apresentadas durante a navegação. Para cada elemento da seqüência do roteiro, o autor deve definir o grau de liberdade associado através da seleção de um dos contextos que contém o elemento (informação ou contexto), conforme ilustrado pela Figura 5.9.

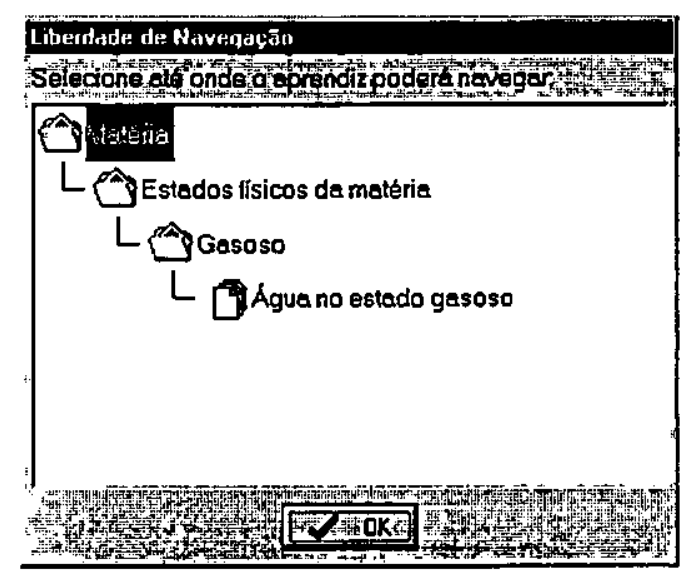

Figura 5.9 - Interface para a definição/seleção do grau de liberdade de navegação

Como visto anteriormente, o grau de liberdade determina o maior contexto em que o aprendiz pode navegar a partir de um elemento do roteiro.

A Figura 5.10 apresenta a interface para a definição de roteiros. $O$ autor define a seqüência do roteiro selecionando as informações ou contextos do hiperdocumento, auxiliado por funções de busca (botão "Selecionar") segundo a classificação das informações quanto à sua função didática, dificuldade e palavras-chave. 


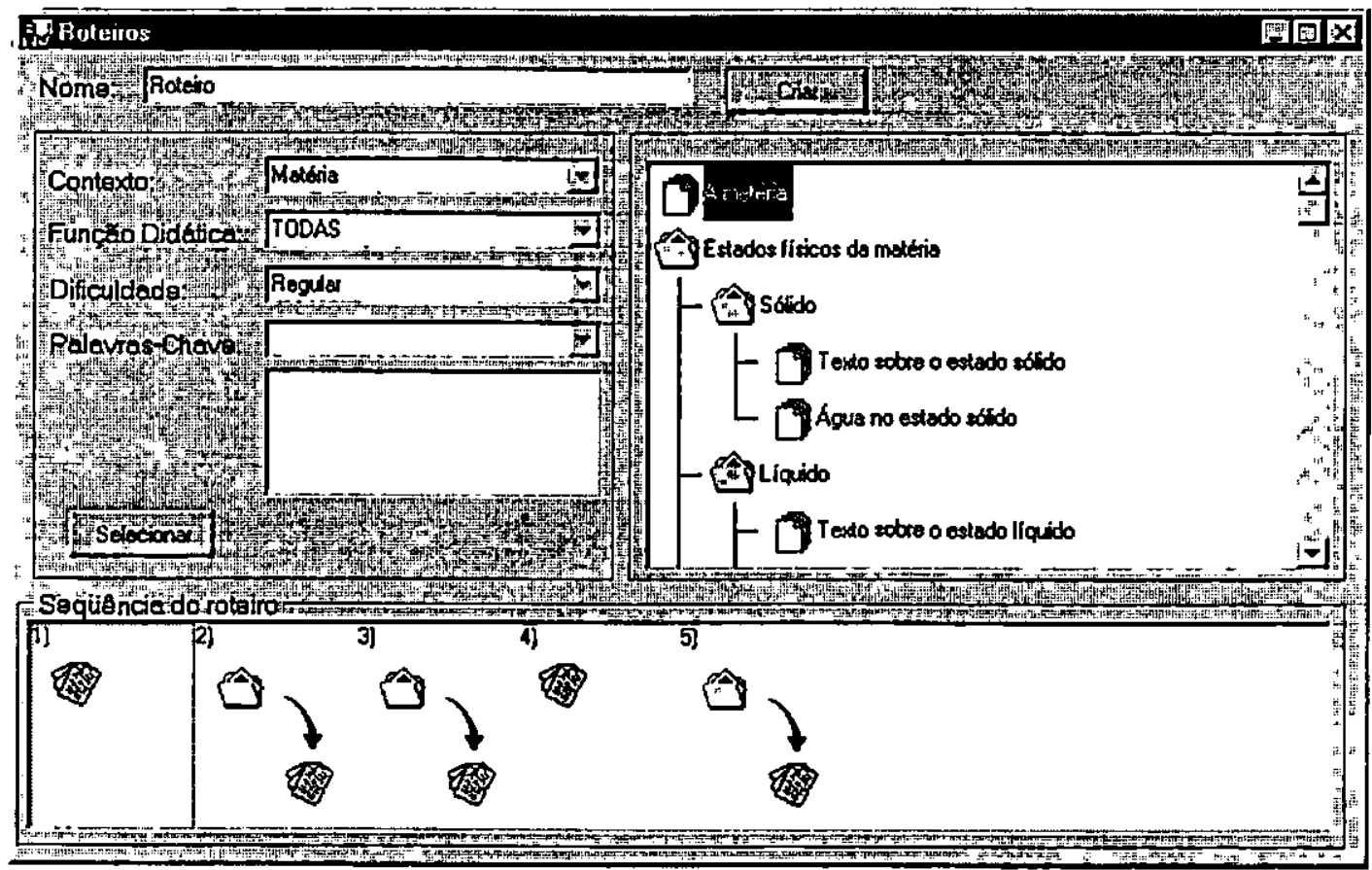

Figura 5.10 - Interface para a definição de roteiros

Sempre que um nó é inserido na seqüência do roteiro, ele é exibido na região situada na parte inferior da janela. Quando o nó liberdade é diferente do nó selecionado, dois ícones são apresentados: o do nó selecionado e o do contexto, que determina seu grau de liberdade. Caso contrário, apenas um ícone, simbolizando o nó escolhido, é apresentado.

\subsection{3 - Modelagem de hiperdocumentos}

Conforme discutido anteriormente, a possibilidade de definir referências arbitrárias entre os objetos de um documento representa a caracteristica marcante de um sistema hipermídia. No entanto, para reduzir a demanda cognitiva sobre o leitor, é necessário combinar essa flexibilidade com mecanismos de organização do documento.

No SASHE, a estruturação lógica do documento é realizada pela introdução do conceito de composição, advindo do MCA, como um agrupamento de componentes do hiperdocumento e das relações (elos) entre esses componentes.

As dificuldades encontradas pelo autor para utilizar esse conceito durante a autoria motivaram Pansanato (1999) a incluir uma ferramenta de modelagem do domínio de hipermídia para ensino no processo de autoria de hiperdocumentos do SASHE. 
Com o objetivo de fornecer uma base para o desenvolvimento dessa ferramenta, foi definido o Método para Projeto de Hiperdocumentos para Ensino (ou EHDM - Educational Hyperdocuments Design Method), que fornece uma série de etapas de desenvolvimento, além de oferecer modelos de representação adequados para descrever o domínio de conhecimento e os aspectos navegacionais de hiperdocumentos para ensino.

Além da definição do EHDM, Pansanato (1999) apresenta a EHDT (Educational Hyperdocuments Development Tooh), um protótipo de ferramenta integrada ao SASHE, que proporciona um ambiente de modelagem para auxiliar a autoria de hiperdocumentos para ensino neste sistema.

\subsection{4 - Importậão e adaptaşão de documentos HTML}

Conforme apresentado anteriormente, o ambiente World-Wide Web caracteriza-se por ser um grande repositótio de informações. Conseqüentemente, apesar das dificuldades, apontadas por Castro (1997), para se encontrar informações com valor educacional, um professor, ou um especialista, com mais experiência em determinado ramo de conhecimento, pode encontrar um ou mais sites que contribuam para uma atividade tutorial/pedagógica pretendida por ele.

No entanto, a questão do processo de aprendizagem inserido num ambiente distribuído, de acordo com Preece et al. (1994), gera duas outras questões:

1. Como deve ser a transmissão de informação referente ao conteúdo educacional?

2. Como se dá o processo cognitivo por trás desses ambientes?

Esses fatores motivaram a definição e implementação do mecanismo de importação/adaptação de material da $W e b$ (descrito em HTML) para o ambiente de autoria do SASHE, pois nesse ambiente o autor encontra funcionalidades para introduzir estratégias tutorias/pedagógicas em suas aplicações hipermídia (hiperdocumentos), bem como para agrupar os elementos de informação em contextos que tratam de um mesmo assunto (domínio de conhecimento).

Essas características permitem o estabelecimento de um equilíbrio entre o controle do aprendiz e do sistema, de modo a oferecer um certo grau de orientação para que o aprendiz possa atingir seus objetivos, sem perder a flexibilidade de leitura (Nunes \& Fortes, 1997). Além disso, o professor pode proporcionar aos aprendizes uma atividade tutorial/pedagógica com um conteúdo atualizado. 
Informações mais detalhadas da Html2Hip, um protótipo de ferramenta capaz de reconhecer a estrutura organizacional de um conjunto de documentos HTML e mapeá-la para a estrutura interna do SASHE, são apresentadas no capitulo 6.

\section{5 - Navegação}

No módulo de navegação, o aprendiz encontra os recursos ilustrados pela Figura 5.11. Aos botões (janela "Controles") estão associadas funções que utilizam, em sua maioria, informações provenientes dos atributos e da contextualização dos nós de informação.

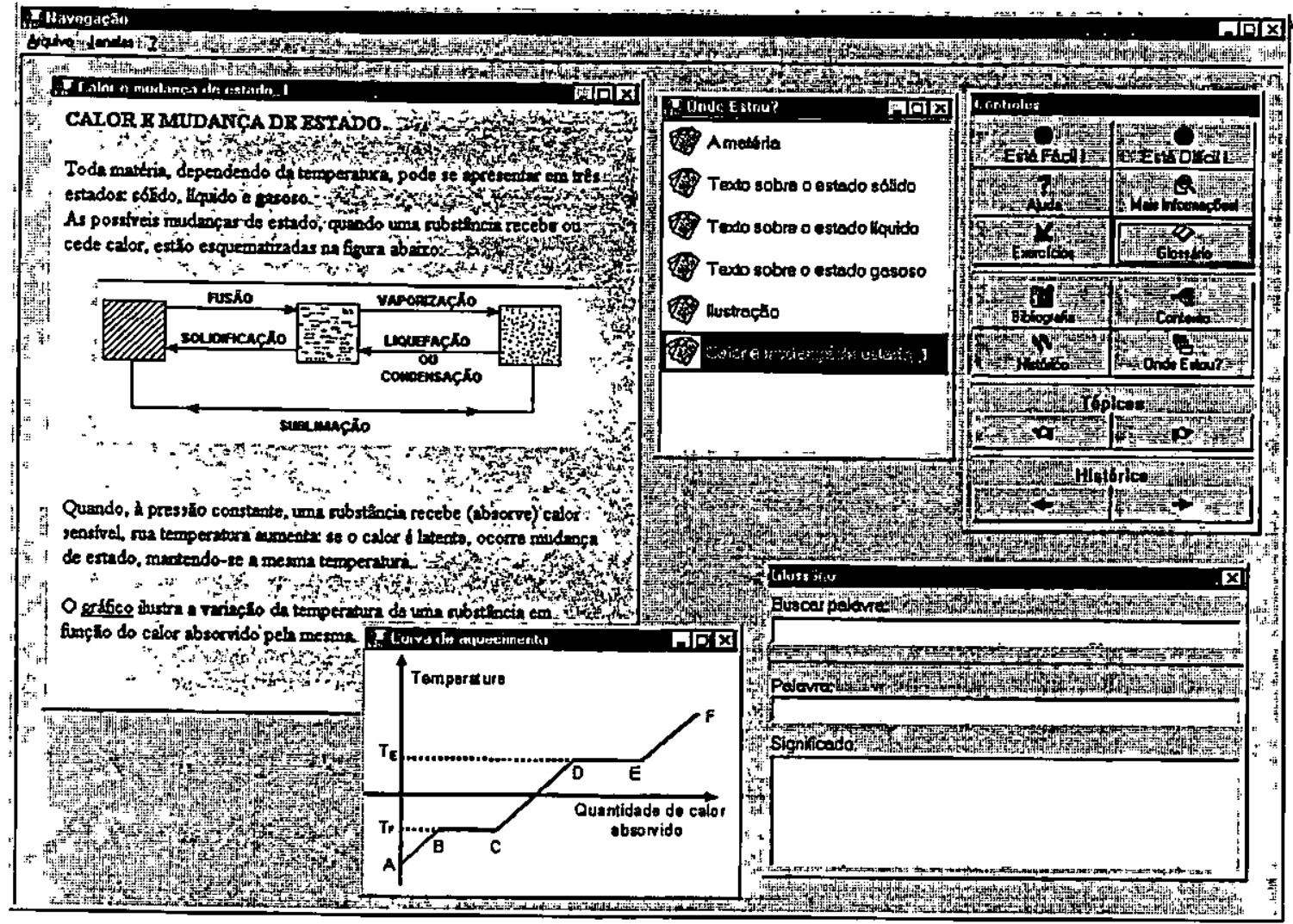

Figura 5.11 - Módulo de navegação (interface do aprendiz)

Os botões "Está Fácil" e "Está Difícil" remetem a estratégias que visam apresentar informações relacionadas ao tópico em questão (do mesmo contexto), porém julgadas de maior ou menor grau de dificuldade, respectivamente. Se o autor criou explicitamente um nó de informação correspondente e de grau de dificuldade diferente, então este será selecionado nessa busca. Caso contrário, uma segunda estratégia considera o atributo "função didática" para a seleção do próximo nó. As duas estratégias são resumidas a seguir: 
1. Procura-se por nós de informação com grau maior de dificuldade/facilidade no mesmo contexto; ou

2. Mostram-se nós de informação com outro atributo de função didática, dependendo do nó de informação atual e de acordo com as correspondências graficamente ilustradas pela Figura 5.12.

"Está Difícil"

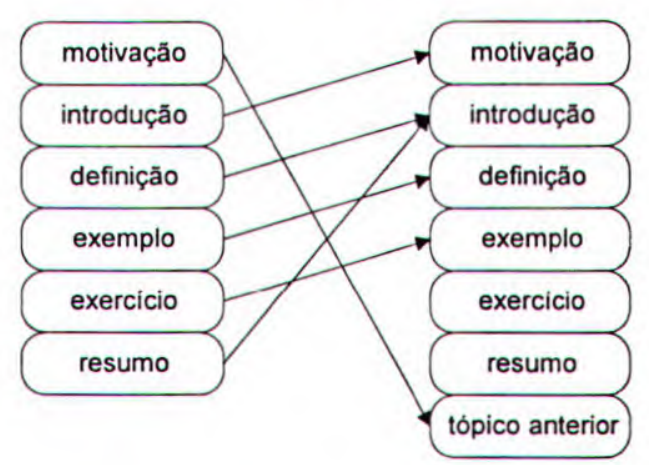

"Está Fácil"

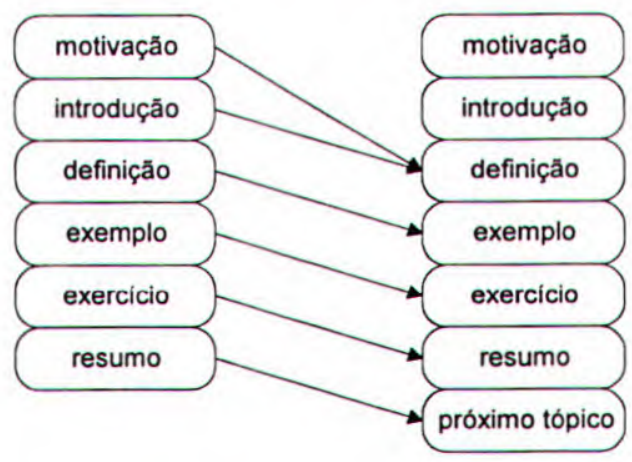

Figura 5.12 - Correspondências entre atributos para estratégias tutoriais embutidas nos botões "Está Fácil" e "Está Dificil" (Nunes et al., 1997)

Essas buscas ocorrem primeiramente no próprio contexto. Se após aplicar a primeira estratégia, o sistema não encontrar um nó de informação alternativo, aplica-se a segunda estratégia. No caso de sucessivos “toques” no mesmo botão ("Está Fácil” ou "Está Difícil”), aplica-se sempre a seqüência "primeira estratégia/segunda estratégia", ou seja, sempre se procura por um nó de informação classificado pelo autor como mais fácil ou mais difícil do que o atual, e apenas se não for encontrado é que as correspondências entre atributos (segunda estratégia) entram em cena.

A interpretação das correspondências implementada na segunda estratégia pode ser feita da seguinte maneira: ao escolher "Está Difícil", por exemplo, e sendo o nó de informação atual um nó com atributo função didática "definição", o sistema procura por outro nó de informação, no mesmo contexto, com atributo "introdução". Caso não haja tal nó, a busca pela tabela continua, ou seja, a partir do atributo função didática "introdução", a escolha do "Está Difícil" remete à busca por um nó de informação com atributo "motivação". Em último caso, a saída via "tópico anterior" no roteiro sempre é alcançada, uma vez que a relação é acíclica.

Os botões "Bibliografia", "Glossário" e "Exercícios" fornecem informações úteis relativas ao domínio, com conteúdos óbvios. A busca, neste caso, ocorre no menor contexto que contém o nó de informação sendo visualizado/apresentado, e a existência desses nós é dependente do processo 
de autoria.

Os botões "Onde Estou?", "Histótico" e "Contexto" auxiliam a orientação do aprendiz. “Onde Estou?" mostra a posição do nó de informação atual (perspectiva) em relação ao roteiro que está sendo percorrido. "Histórico" situa o nó atual na trilha de nós já percorridos, sendo que esta pode coincidir ou não com o roteiro, dependendo se o aprendiz seguiu fielmente a trilha planejada. "Contexto" mostra o contexto correspondente ao grau de liberdade do nó atual, incluindo os demais nós e todas as ligações do nó de contexto. Dessa forma, o aprendiz é informado sobre o contexto dentro do qual ele pode navegar sem, contudo, fugir do roteiro.

"Mais informações" é um botão de interface que dispara a busca por uma lista, em todo o hiperdocumento, de nós que possuam uma ou mais palavras-chave em comum com o nó atual. $O$ aprendiz poderá visualizar qualquer um dos nós selecionados.

Finalmente, o par de botões "Tópicos" serve para avançar e retroceder no roteiro, e o par de botões "Histórico" serve para avançar e retroceder na trilha percorrida pelo aprendiz.

\section{6 - Comparação entre os ambientes apresentados}

A possibilidade de utilização das tecnologias Web na educação começou a ser explorada de forma mais efetiva apenas no final de 1996, quando o termo Web-based education começou a se popularizar.

Objetivando fornecer diretrizes para pesquisa, discussão e desenvolvimento, também começaram a surgir propostas de análise e comparação de ambientes de ensino/autoria mantidos na World-Wide Web. Entre esses trabalhos, destacam-se: o modelo de ambiente educacional distribuído proposto por Campbell et al. (1995); o modelo conceitual para a comparação de ambientes de ensino mantidos na WWW proposto por Crespo et al. (1998); os critérios de comparação entre ambientes de ensino e aprendizagem propostos por Gibson et al. (1996); entre outros.

O objetivo desta seção é traçar uma comparação entre os ambientes de autoria/criação, estruturação e distribuição de material didático apresentados no capítulo 3, e os ambientes de autoria e navegação do SASHE. Para isso, foram observados os seguintes critérios:

- O ambiente permite interação entre os usuários (professores, autores e aprendizes)?

Nesse contexto, segundo Hardin e Ziebarth (1995), existem dois tipos de tecnologias que podem ser encontradas em ambientes de ensino/aprendizagem: comunicação assincrona (correio- 
eletrônico e grupos de interesse/discução) e comunicação síncrona (vídeo-conferência, editores cooperativos, sessões de bate-papo). A utilização de uma destas tecnologias ou da combinação delas irá determinar o grau de interação entre indivíduos permitido, ou disponibilizado, pelo sistema.

Entre os ambientes apresentados, o único que não permite interação entre os seus usuários, assim como o SASHE, é o pacote de ferramentas desenvolvidas por Santos (1998).

- Sāo oferecidos mecanismos/ferramentas para modelar o domínio de conhecimento do: hiperdocumentos criados e/ou processados pelo ambiente?

Conforme apresentado anteriormente, o emprego de tecnologia hipermídia em ambientes de ensino e aprendizagem apresenta basicamente dois aspectos críticos: a autoria e a navegação. Estes dois aspectos podem ser vistos como independentes, mas certamente um bom processo de autoria pode amenizar os problemas de desorientação e sobrecarga cognitiva durante a navegação. Além disso, é válido reforçar que os problemas de desorientação do usuário (leitor/aprendiz) são, muitas vezes, frutos de falhas no processo de modelagem dos aspectos navegacionais dos hiperdocumentos.

No entanto, todos os ambientes analisados baseiam-se na simples divulgação do materi: didático (em manuais de referência e tutoriais), mantendo forte identidade com o materi: impresso, ou seja, utilizam algum critério para fragmentar o conteúdo em páginas. O critéri mais comum é a partição do conteúdo em itens e subitens relacionados a um assunto, criand uma hierarquia semelhante a um livro.

$O$ ambiente de autoria do SASHE, por sua vez, conta com um módulo de modelagem (a ferramenta EHDT) que tem como principal objetivo auxiliar o autor (professor) quanto à organização de seu material didático.

- Sāo oferecidos mecanismos para reutilizaçāo dos conteúdos já existentes em mídia digital, através da importação de arquivos, por exemplo?

Todos os ambientes apresentados, inclusive o SASHE, possuem algum mecanismo de reutilização de material (seja ele texto, imagem, vídeo ou áudio). Porém com algumas ressalvas, como por exemplo, o InterBook, cujo ambiente de autoria é baseado na plataforma Macintosh. Logo, uma imagem do tipo WMF (Windows Meta File) deverá passar por um processo de 
conversão antes de ser incluída como um elemento de um hiperdocumento a ser processado por esse ambiente.

No SASHE, durante a execução de um processo de importação, conforme será apresentado no capitulo 6, os arquivos texto (HTML e TXT) e os arquivos imagem (TIF, GIF, PNG e JPG) também passam por um processo de conversão antes de serem inseridos em um hiperdocumento.

- O ambiente utiliza um navegador proprietário (desenvolvido como um componente do sistema) ou um navegador genérico (Netscape Comunicator, Microsoft Internet Explorer, Hot Java, entre tantos outros)?

Todos os ambientes apresentados utilizam-se de navegadores genéricos. Logo, o controle da navegação limita-se aos recursos oferecidos pelos browsers: distinção de uma página visitada ou não, histórico da navegação, bookmarking e backtracking (Pimentel \& Hagui, 1996).

No entanto, o Interbook, utilizando-se de três técnicas de adaptação, o aconselhamento direto, a anotação adaptativa e a classificação adaptativa propostas por Brusilovsky (1996), implementa um script que oferece apoio ao aprendiz durante a navegação em uma sessão (histórico da navegação, etapa de conhecimento e pré-requisitos). Porém, não implementa estratégias tutoriais bem definidas como as do navegador (proprietário) do SASHE, discutidas na seção 5.5 .

- O sistema permite a visualização parcial ou total da estrutura dos hiperdocumentos, provendo, assim, uma orientação de localização ao usuário (seja ele o autor ou o aprendiz)?

No caso de sistemas hipermídia, os editores gráficos, ou browsers estruturais, são de fundamental importância para a manipulação/visualização (total ou parcial) das estruturas organizacionais dos hiperdocumentos, pois além de facilitar a navegação, ajudam a restabelecer o senso de localização do usuário, quando ele está desorientado.

Nenhum dos ambientes analisados oferece a possibilidade de análise estrutural total ou parcial dos hiperdocumentos por eles criados/processados. Uma exceção a esse contexto pode ser encontrada no SASHE, pois além do navegador tradicional, ele oferece dois browsers que permitem a visualização e edição da estrutura organizacional de hiperdocumentos: o browser Estrutural e o browser Gráfico. 


\section{- O ambiente oferece suporte multiplataforma e independência tecnológica?}

Segundo Dunlop (1998), um sistema hipermidia deve apresentar as mesmas características e funcionalidades independentemente do sistema operacional e da plataforma computacional na qual está sendo executado, bem como garantir que as suas aplicações (hiperdocumentos) sejam executadas sem modificações à medida que a tecnologia evolui.

Dentre os ambientes analisados, apenas o AulaNet apresenta limitações quanto a esse critério. Nesse sistema, os recursos oferecidos utilizam-se de plug-ins dos mais diversos fabricantes de tecnologias hipermidia/multimídia (Aulanet, 1999). Dessa forma, não podemos garantir que toda e qualquer aula (ou sessão), preparada pelo ambiente, não apresentará incompatibilidades na medida em que o ambiente e/ou os plug-ins forem evoluindo.

O SASHE, por sua vez, é baseado em Microsoft Windows 95/98. Além disso, não apresenta mecanismos de distribuição de seus hiperdocumentos. Logo, esses fatores restringem a sua utilização em larga escala.

- São oferecidos recursos ou funcionalidades para avaliação do nível de aprendizagem?

Segundo Santos (1998), uma atividade de avaliação é importante no contexto dos ambientes de ensino, pois possibilita ao professor obter o feedback dos aprendizes em relação ao material apresentado, permitindo assim, a melhoria da qualidade e evolução desse mesmo material.

No entanto, torna-se questionável se os resultados apresentados por uma sessão de exercícios realmente fornecem o quanto de aproveitamento foi obtido por um determinado aprendiz, pois geralmente, as questões são do tipo falso e verdadeiro, escolha de alternativas corretas, relacionamento de colunas, entre outras. Dessa forma, o aprendiz pode responder ao conjunto de questões de forma aleatória, e por sorte, obter um bom resultado.

Todos os ambientes analisados apresentam a possibilidade de inserção de exercícios ou atividades de avaliação na estrutura de seus hiperdocumentos. No SASHE, também foi prevista essa funcionalidade, porém ainda não foi implementada. 


\section{7 - Considerações finais do capítulo}

A extensão e a forma de controle ao usuário de uma aplicação hipermídia constituem um tema bastante debatido na literatura de hipermídia. Nesse sentido, muitos trabalhos argumentam que um ambiente de ensino deve prover orientação ao aprendiz para alcançar os objetivos almejados pelo professor (autor) da atividade tutorial/pedagógica.

O protótipo de ambiente de autoria e navegação SASHE, por sua vez, apresenta argumentos para o uso de recursos bastante simples e já difundidos em propostas tecentes, tais como a definição de atributos dependentes de domínio e a contextualização de nós, que auxiliem na autoria de roteiros com niveis de liberdade definidos pelo autor do hiperdocumento.

No próximo capítulo encontra-se uma descrição detalhada do mecanismo de importação/adaptação de documentos HTML para a representação interna do SASHE proposto por este trabalho, bem como as principais caracteristicas e funcionalidades da $\mathrm{Html2Hip,} \mathrm{um} \mathrm{protótipo} \mathrm{de} \mathrm{ferramenta} \mathrm{de}$ importação de documentos HTML, que foi incorporada ao ambiente de autoria do SASHE. 


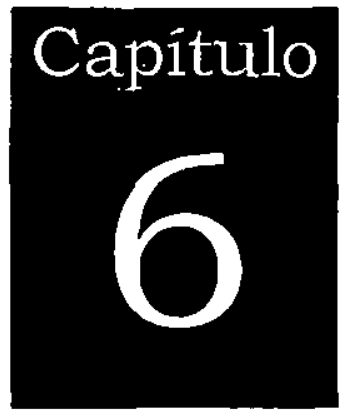

\section{Htm12Hip - \\ Uma ferramenta de importação de documentos HTML}

\section{1 - Considerações iniciais}

Este capítulo apresenta a Html2Hip, um protótipo de ferramenta de importação e adaptação de documentos HTML para a representação interna do SASHE, que se baseia na estruturação de objetos multimídia segundo a hierarquia de classes proposta pelo MCA (Modelo de Contextos Aninhados) (Casanova et al., 1991; Soares et al., 1994, 1995a).

O protótipo da ferramenta $\mathrm{Htm} 2 \mathrm{Hip}$ foi desenvolvido como uma ferramenta de suporte automatizado integrada ao SASHE, e pode facilitar o trabalho de autoria em duas situações distintas:

1. Na importação de um documento HTML que contém várias páginas e imagens, através de um único comando.

2. Na criação de novos hiperdocumentos, o protótipo de ferramenta de modelagem EHDT proposto por Pansanato (1999), também integrado ao SASHE, utiliza um mecanismo de geração para criar apenas "esqueletos" (páginas com ligações). Cada "esqueleto" está associado a uma informação (nó terminal), e é composto por um arquivo do tipo texto com os elos necessários 
para a navegação. Pretende-se que, futuramente, o conteúdo desses “esqueletos" possa ser preenchido com os recursos de mapeamento e conversão utilizados pelo mecanismo de importação.

A seção 6.2 apresenta os requisitos definidos como base para a implementação do protótipo da ferramenta Html2Hip. A seção 6.3 apresenta a arquitetura dos módulos da Html2Hip. Em seguida, na seção 6.4, encontra-se uma descrição detalhada do mecanismo de importação e de seus componentes.

Finalmente, a seção 6.5 é dedicada à apresentação das principais características e funcionalidades da Html2Hip. Nessa seção, durante a exposição dos conceitos, sezá apresentado um exemplo de mapeamento/adaptação de um documento HTML para a representação interna do SASHE.

\section{2 - Requisitos}

A Html2Hip tem como principal objetivo facilitar a autoria de hiperdocumentos no SASHE, através da importação e adaptação de material instrucional armazenado em mídia digital (arquivos HTML).

Dessa forma, durante as fases de experimentação e implementação, foram considerados como diretrizes para o desenvolvimento do protótipo, os seguintes requisitos:

- Reconhecer a estrutura organizacional (nós, âncoras e elos) de um conjunto de documentos HTML e mapeá-la para a estrutura interna do SASHE, que é baseada em Modelo de Contextos Aninhados;

- Converter documentos descritos segundo o padrão HTML para o padrão RTF (formato padrão empregado nos nós de informação do tipo tex to do SASHE);

- Converter imagens do tipo TIF, GIF, PNG e JPG (largamente empregadas em documentos Web devido à sua taxa de compactação) para o formato BMP (formato padrão empregado nos nós de informação do tipo imagem do SASHE);

- Oferecer um Web-browser, com o qual o usuátio possa navegar pela Internet sem ter que sair do ambiente de autoria do SASHE. Esse browser também deve fornecer mecanismos de importação e adaptação das páginas sendo visitadas. 


\section{3 - Arquitetura da ferramenta Html2Hip}

A Figura 6.1 apresenta, esquematicamente, a arquitetura dos módulos componentes da Html2Hip, de modo a jlustrat o mecanismo de importação de documentos HTML proposto durante a fase de experimentação deste trabalho.

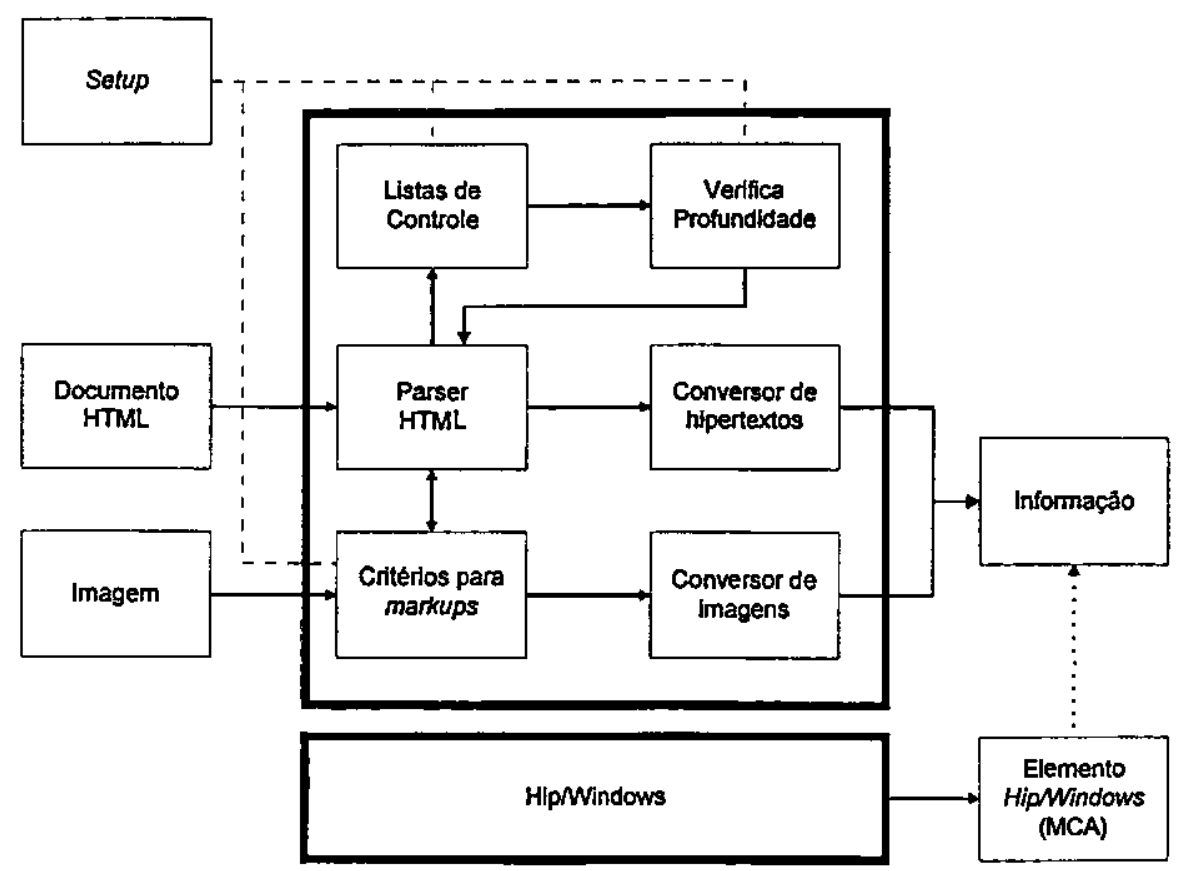

Figura 6.1 - Arquitetura da ferramenta Himl2Hip

Conforme apresentado na seção 5.3, a camada Hip/Windows implementa abstrações definidas pelo Modelo de Contextos Aninhados. O protótipo de ferramenta Html2Hip utiliza diretamente as funções implementadas por essa camada para:

- Inserir nós (informação ou contexto) em um hiperdocumento;

- Inserir âncoras em um nó de informação do tipo texto;

- Inserir elos em um contexto;

- Definir os atributos de um nó terminal.

O protótipo atual da Html2Hip foi desenvolvido utilizando-se os recursos oferecidos pelo ambiente de programação Borland Delphi 4.0. Esse ambientc também foi empregado no desenvolvimento da interface do SASHE. 


\section{4 - Importação de documentos HTML}

Em termos genéricos, o mecanismo de importação/adaptação, pode ser resumidamente descrito como: obedecendo-se a um conjunto de propriedades de importação (Setup: profundidade, incorporar imagens ou não, palavras-chave e atributos do SASHE), um conjunto de arquivos HTML e suas respectivas imagens, ou apenas um arquivo imagem, passa por um processo de mapeamento e conversão, inserindo elementos de informação (nós terminais e/ou de contexto) em um hiperdocumento do SASHE.

As próximas sessões apresentam as principais características do mecanismo de importação, bem como informações detalhadas dos componentes da Html2Hip.

\subsection{1 - Definif̧ão dos atributos de importậão (Setup)}

Antes de executar uma importação, o usuário (autor) precisa definir alguns atributos, ou variáveis de ambiente, que implicam na estruturação e qualificação dos nós de informação a serem inseridos no hiperdocumento. São elas:

- Profundidade: determina o nível limite de elementos do documento HTML (nós, âncoras e elos) que devem ser processados durante uma importação.

Essa funcionalidade foi desenvolvida utilizando-se o conceito de nível de um nó em uma árvore, que representa a distância de um nó até a raiz. Assim, na ferramenta de importação, se o usuário definir uma profundidade igual a 4, todos os nós (páginas HTML e suas respectivas imagens) da hierarquia de relacionamentos do documento, que possuem nível menor ou igual a 4, serão inseridos no hiperdocumento. Na implementação atual, pode-se definir uma profundidade que esteja entre 0 e 5 .

- Exibir imagens: determina se as imagens do(s) documento(s) HTML de entrada também serão processadas, inserindo elementos de informação do tipo imagem no hiperdocumento.

Quando documentos HTML são visualizados pela fertamenta de importação, suas imagens também são automaticamente carregadas. Entretanto, se no menu de opções o item "Exibir imagens" não estiver selecionado, quando um documento HTML é carregado, um pequeno icone é visualizado na posição de cada imagem. Nesse caso, durante o processo de importação, 
as etiquetas de inserção de imagens da HTML (IMG) são ignoradas, e, por conseguinte, são inseridos no hiperdocumento apenas informações textuais.

- Atributos do SASHE: determinam os atributos (assunto, função didática, dificuldade e palarraschave) dos elementos de informação a serem inseridos no hiperdocumento.

Essas informações, conforme apresentado anteriormente, permitem a definição de recursos adicionais de navegação para o aprendiz. $\mathrm{Na}$ versão atual da $\mathrm{Html2Hip}$, durante o processo de importação, todos os elementos de informação (páginas HTML e suas respectivas imagens) são qualificados com os mesmos atributos.

\subsection{2 - Iistas de controle}

Para que o protótipo de hiperdocumento produzido a partir de um processo de importação possua as mesmas caracteristicas organizacionais que o documento HTML original, o mecanismo de importação precisa manter uma relação dos objetos subordinados ao documento HTML (páginas, imagens, âncoras e elos). Dessa maneira, dưante a implementação do mecanismo de importação, foi definido um conjunto de listas de controle, nas quais são armazenadas essas informações.

A Figura 6.2 ilustra a hierarquia de classes (objetos) de um hiperdocumento criado com o auxilio da ferramenta Html2Hip.

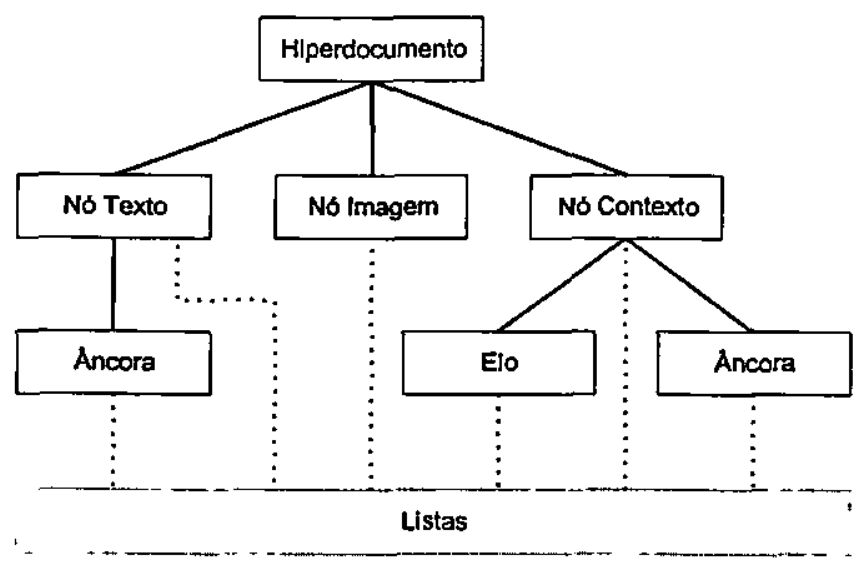

Figurn 6.2 - Hierarquia de classes um documento criado com a Html2Hip

As listas são preenchidas com fragmentos de informação (conteúdo de etiquetas e/ou atributos de etiquetas) dos arquivos HTML, que eventualmente estejam sendo processados pela ferramenta de importação. 
Conseqüentemente, foi implementado um parser (HTML Minimal Parser) que oferece tratamento especial para:

- As etiquetas de inserção de imagem (IMG), inserindo o conteúdo de seu atributo SRC (teferência a um arquivo imagem) em uma lista de controle (imagens a serem processadas);

- O elemento âncora $(\angle A\rangle$ conteúdo $\langle/ A\rangle)$, cujo conteúdo determina o texto a ser ancorado. Nesse caso, existem duas listas de controle: uma que indica o nó de informação onde será criada a âncora, e outra que indica a posição de início da âncora dentro do nó de informação;

- O atributo HREF da etiqueta de marcação de âncora ( $A$ ), que determina o destino da âncora, ou seja, um outro arquivo HTML a ser processado.

Devido a características da biblioteca de classes da camada Hip/Windows, foram definidas duas listas de controle adicionais, nas quais são inseridas informações do contexto em que as âncoras e os elos devem ser definidos.

\subsection{3 - HTML Minimal Parser}

O processo de conversão de um documento HTML para um documento RTF exigiu a implementação de um mecanismo capaz de: a) separar as etiquetas HTML do conteúdo textual do documento; e b) aplicar ao conteúdo textual as propriedades e ações sugeridas pelas etiquetas.

Esse mecanismo corresponde a um parser, chamado de HTML Minimal Parser, que reconhece e interpreta apenas as seguintes tags e identificadores:

- Elemento <TITLE> conteúdo </TITLE>, cujo conteúdo determina o nome do nó de informação do tipo texto a ser inserido no hiperdocumento;

- Âncoras definidas pelo elemento $\angle \mathrm{A} H \mathrm{HEF}=$ "destino" $\rangle$ conteúdo $\langle/ \mathrm{A}\rangle$, cujo destino seja outro arquivo, pois o SASHE, conforme apresentado nas subseções 4.3.2 e 5.4.1, só permite a definição de elos externos. Nesse caso, o valor do atributo HREF indica um novo arquivo HTML a ser processado, e o conteúdo indica o texto a set ancorado. 
- Elemento para inserção de imagens: <IMG $\mathrm{SRC="imagem"} \mathrm{ALT="descrição">.} \mathrm{Nesse}$ caso, "imagem" faz referência a um arquivo imagem a ser processado e "descrição" indica o nome do nó de informação do tipo imagem a ser inserido no hiperdocumento.

Todavia, o padrão HTML não exige que o atributo ALT receba necessariamente um valor. $\mathrm{Na}$ verdade, ele pode até ser omitido. Nesse caso, durante o processamento de uma etiqueta de inserção de imagem, se não for encontrado o atributo ALT, o elemento de informação recebe o nome do arquivo imagem associado a ele.

- Formatação de estilo de caracteres (negrito, itálico, sobrescrito);

- Formatação de parágrafos (parágrafo, quebras-de-linha, tabulações, alinhamento à esquerda e centralizado);

- Listas năo-ordenadas. Caso o arquivo HTML possua uma lista ordenada, ela é automaticamente convertida para uma não-ordenada;

\section{- Caracteres especiais.}

Durante a análise do arquivo HTML, o parser insere itens em algumas listas de controle. O conteúdo dessas listas de controle determina os próximos arquivos HTML ou arquivos-imagem a serem processados pelo mecanismo de importação.

Conforme apresentado anteriormente, durante o processo de parsing, são extraídos dos elementos de inserção de imagem e dos elementos de definição de âncora fragmentos de informação, que determinam o nome dos elementos a serem inseridos no hiperdocumento. Esses fragmentos de informação são processados pelo módulo "Critérios pasa markup", que tem como principal funcionalidade evitar a duplicidade de identificadores. A string resultante desse processamento é enviada para uma função da camada $\mathrm{Hip} / \mathrm{Windows,} \mathrm{implicando} \mathrm{em} \mathrm{alguma} \mathrm{modificação} \mathrm{na} \mathrm{estrutura}$ organizacional do hiperdocumento (criação de nó de contexto ou informação, definição de uma âncora ou elo, modificação dos atributos de um elemento de informação etc.).

Além disso, o parser, na medida em que vai analisando o arquivo, gera um arquivo temporário contendo o conteúdo textual do arquivo HTML de entrada e palavras e símbolos de controle que forem necessátias. Terminada a análise do arquivo, é gerado um arquivo RTF, que nada mais é do que a representação física (conteúdo) de um elemento de informação do SASHE. 
Todo esse mecanismo está esquematicamente representado pela Figura 6.3.

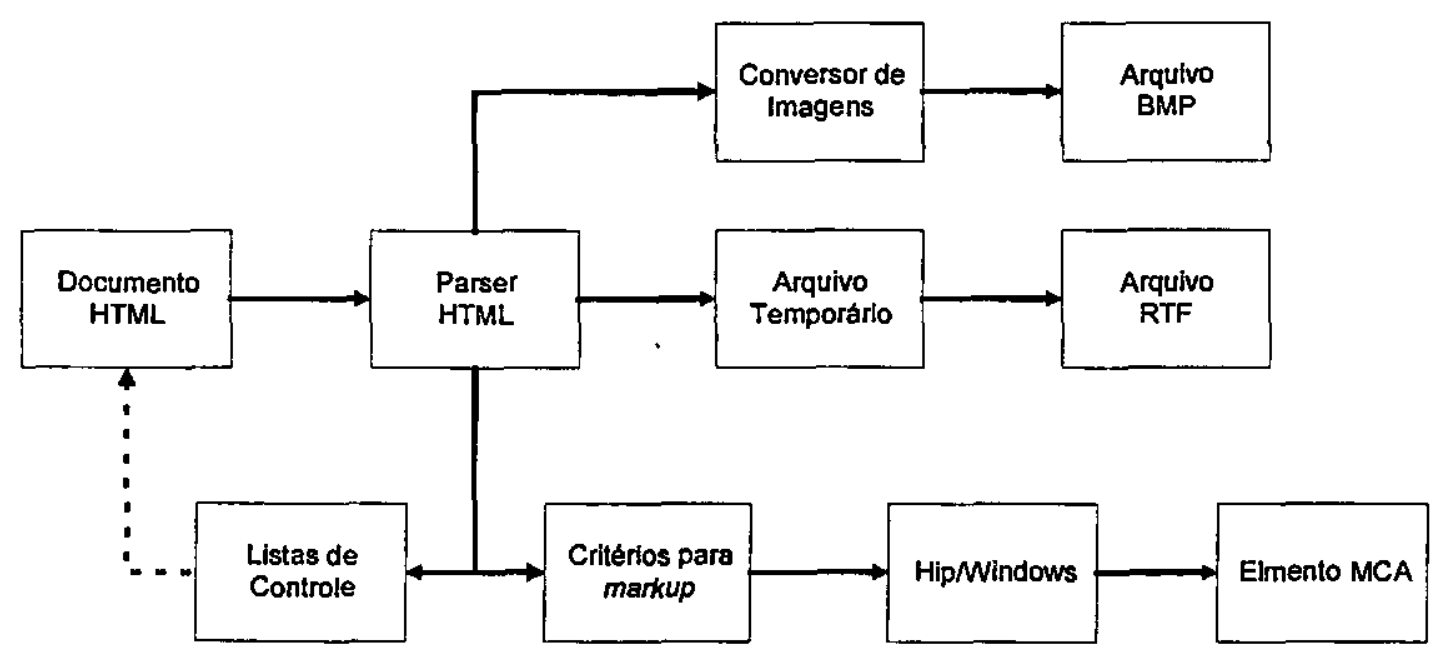

Figura 6.3 - Parsing de um documento HTML

A linha pontilhada indica que nem toda referência a um arquivo HTML, ou a um arquivo imagem, vai ser processada, pois somente são processados arquivos que estejam em um nível da hierarquia de relacionamentos menor ou igual ao valor atribuido à propriedade profundidade.

As características de um arquivo HTML reconhecidas por esse parser forneceram as diretrizes para o desenvolvimento do editor de conteúdo de nós de informação do tipo texto, ilustrado pela Figura 5.7 da subseção 5.4.1.

Como os nós de informação do tipo texto são visualizados tanto no ambiente de navegação, como no ambiente de autoria, no formato HTML, foi também desenvolvida uma função de conversão de documentos RTF para documentos HTML. Conseqüentemente, foi implementado um parser RTF (Minimal RTF Parser) que reconhece e processa control words e control symbols, transformando um arquivo RTF em um arquivo HTML (temporário).

\subsection{4 - Critérios para markup}

Durante a análise de um arquivo HTML, o elemento 〈TITLE> conteúdo </TITLE> e o atributo ALT do elemento <IMG SRC="arquivo.imagem" ALT="conteúdo"> merecem atenção especial, pois os seus conteúdos determinam, respectivamente, o nome dos nós de informação do tipo texto e o nome dos nós de informação do tipo imagem, a serem inseridos em um hiperdocumento do SASHE. 
Todavia, pode ocorrer que durante um ou mais processos de importação, apareçam arquivos HTML cujo elemento título possua o mesmo conteúdo e imagens cujas descrições sejam as mesmas. Nesse caso, para evitar problemas com duplicidade de nomes (identificadores), foi criada uma função que verifica a existência de um elemento de informação com um determinado nome na estrutura de um hiperdocumento. Se o resultado da busca for positivo, no final da string que determina o nome do nó é inserida a sequêencia de caracteres "-1". E novamente é feita a busca pela estrutura do hiperdocumento. Se novamente o resultado da busca for positivo, o caractere "1" é substituído pelo caractere "2". E assim sucessivamente, até que o resultado da busca apresente resultado negativo.

\subsection{5 - Definição de contextos}

Conforme apresentado anteriormente, o usuário (autor) deve estar muito atento durante a definição dos contextos em seu hiperdocumento, quer ele esteja utilizando as funcionalidades do ambiente de autoria, o ambiente de modelagem ou a fertamenta de importação, pois os contextos de um hiperdocumento devem estat recursivamente aninhados, partindo de contextos com informações mais gerais para contextos com informações mais específicas. Uma organização, assim, assinalada facilita a orientação do próprio autor na medida em que o hiperdocumento for crescendo.

O mecanismo de importação, por sua vez, reconhece a estrutura de um arquivo HTML de entrada e insere elementos de informação em um hiperdocumento que esteja sendo editado no ambiente de autoria do SASHE. Mais especificamente, os novos elementos de informação podem ser inseridos em qualquer contexto do hiperdocumento, inclusive em um contexto inexistente. Nesse caso, a ferramenta de importação cria esse contexto.

Além disso, durante a análise da estrutura de um arquivo HTML, se a opção "Exibir imagens" estiver selecionada e for encontrado um ou mais elementos de inserção de imagens, cria-se um novo contexto e nele são inseridos um nó de informação do tipo texto com o conteúdo textual do arquivo e um nó de informação do tipo imagem para cada elemento IMG encontrado.

\subsection{6 - Conversão de arquivos imagem}

Em um processo de importação, não são apenas arquivos HTML que passam por um processo de mapeamento, adaptação e conversão para gerar nós de informação em um hiperdocumento do SASHE, pois à estrutura desses arquivos podem estat associadas uma ou mais imagens. 
Essas imagens geralmente encontram-se armazenadas em formato JPG, TIF, GIF ou PNG, que possuem uma alta taxa de compactação, facilitando a sua transferência pela Internet. No entanto, o SASHE utiliza em seus hiperdocumentos imagens do tipo BMP. Assim, quando o mecanismo de importação vai processar uma imagem, e esta, por sua vez, estiver armazenada em qualquer outro formato à exceção do BMP, é realizada uma conversão.

A Figura 6.4 apresenta, esquematicamente, o mecanismo de conversão de imagens.

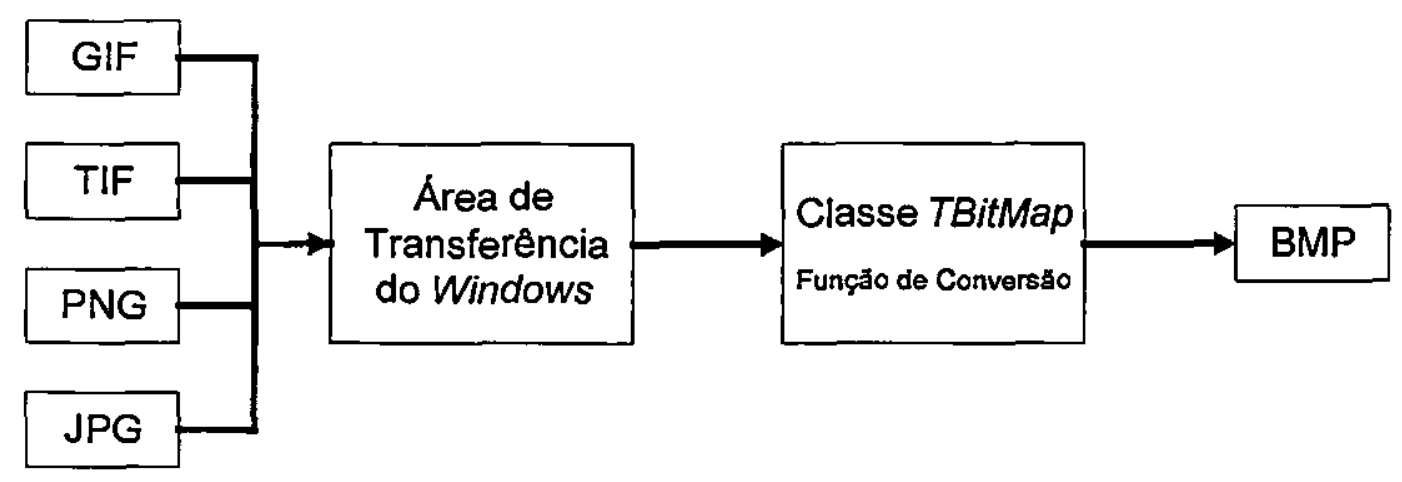

Figum 6.4 - Mecanismo de conversāo de imagens

Esse mecanismo pode ser, resumidamente, explicado em 4 etapas:

1. O conteúdo do arquivo imagem é enviado para a área de transferência do Windows,

2. Cria-se uma instância BitMap com a classe TBitMap pertencente à API"1 do Windows;

3. A tribuí-se o conteúdo da área de transferência para essa instância;

4. Salva-se o conteúdo dessa instância em um arquivo.

Desse modo, um arquivo imagem que esteja armazenado em qualquer formato pode ser convertido para BMP, e ser inserido como um elemento de informação em um hiperdocumento do SASHE.

"I API (Application Program Interface - Interface para Programa Aplicativo) é o conjunto de rotinas ou funçōes, ou a biblioteca getal de funções $e$ rotinas internas, que o sistema operacional coloca à disposição dos aplicativos que requisitarem seus serviços, ou que um programa utiliza para solicitar serviços executados por outros programas aplicativos ou pelo sistema operacional. 


\section{5 - Exemplo de utilização da Html2Hip}

Esta seção apresenta um exemplo de utilização da Html2Hip para ilustrar e avaliar a utilização desse protótipo de ferramenta no desenvolvimento de hiperdocumentos para o SASHE. Nesse contexto, é recomendado empregar a seguinte metodologia de desenvolvimento:

1. Obter o conjunto de documentos HTML e armazená-lo em um diretório local;

2. Preparar o ambiente de importação;

3. Definir as propriedades de importação;

4. Gerar um protótipo de hiperdocumento;

5. Avaliar o protótipo obtido.

As subseções seguintes descrevem essas etapas de desenvolvimento.

\subsection{1 - Obtenção de material didático da Web}

A versão atual da Html2Hip processa apenas arquivos armazenados localmente, ou seja, os arquivos HTML a serem importados/processados devem estar armazenados em um diretório da máquina onde está sendo executado o ambiente de autoria do SASHE.

Dessa forma, para facilitar a obtenção de arquivos da Web foi implementado um Web-browser para que o autor possa navegar pela Internet sem ter que sair do ambiente de autoria do SASHE.

A Figura 6.5 ilustra a interface do Web-browser, que está exibindo o conjunto de documentos interativos utilizado como material de apoio na disciplina SCE126 - Introdução à Compilação, do Instituo de Ciências Matemáticas de Computação (ICMC-USP). Esse hiperdocumento foi construido com o auxílio da ferramenta HyperBuilder desenvolvida por Santos (1998). 


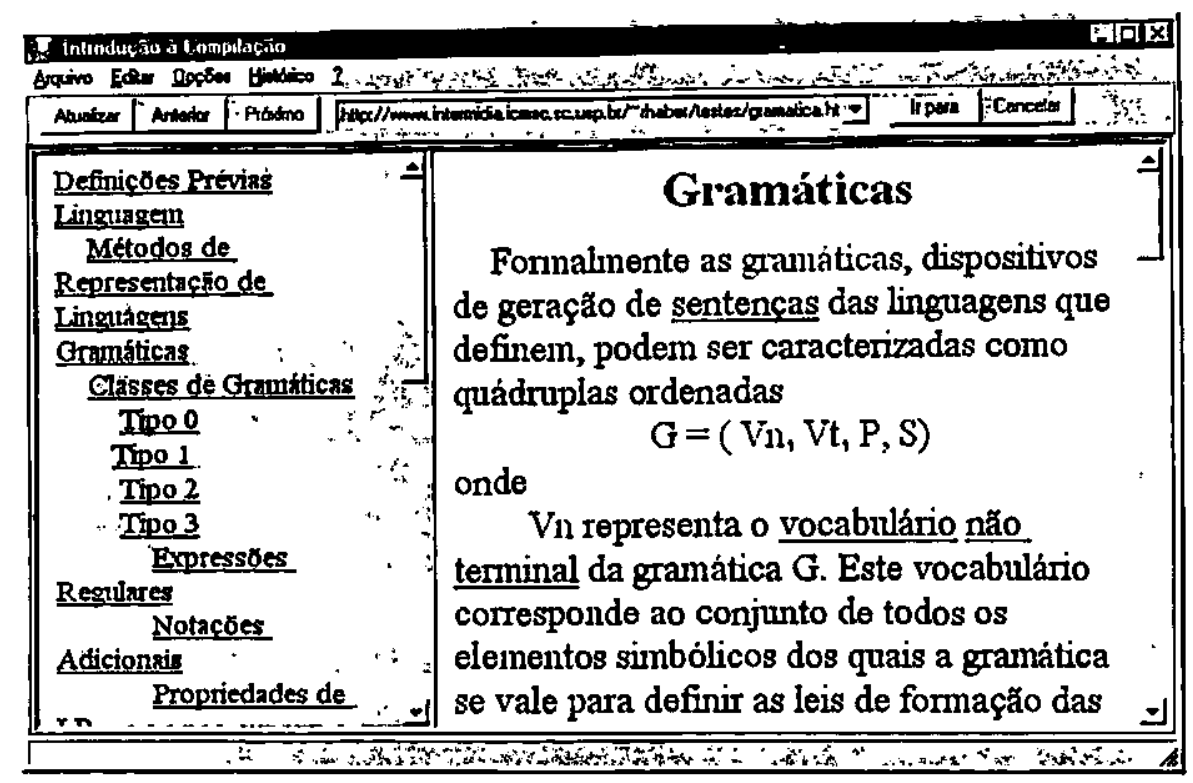

Figura 6.5 - Interface do W $a b$-browser

Esse browser, que se encontra integrado ao ambiente de autoria do SASHE e ao protótipo de ferramenta $\mathrm{H} t \mathrm{ml} 2 \mathrm{Hip}$, oferece para o autor as mesmas funcionalidades de importação e adaptação da Hrml2Hip, exceto a determinação de um valor para a profundidade. Dessa forma, ele permite que sejam inseridos apenas hiperdocumentos e/ou imagens sendo visitados/apresentados.

Uma característica interessante fot a incorporação de um cache a esse browser, onde são armazenados todos os elementos de informação (imagens, áudio, vídeos etc.) das páginas visitadas.

Para evitar problemas de duplicidade de nomes, o primeiro arquivo HTML armazenado recebe o nome de "m00001.html", o segundo recebe o nome de "m00002.html", e assim sucessivamente. Para cada tipo de arquivo imagem (BMP, TIFF, JPG, GIF e PNG), ou qualquer outro elemento que seja apresentado pelo browser, inicia-se uma nova seqüência.

Futuramente, pode ser incorporado um mecanismo de importação que processe os arquivos armazenados no cache, pois ele mantém um arquivo (cacheinfo.txt) no qual, para cada elemento armazenado, existe uma entrada que indica o endereço original do elemento e o nome que foi atribuido a ele, tal como:

intermidia.icmsc.sc.usp.br/ rhaber/testes/gramatica.html m00063.html 
Todavia, não se pode ignorar o fato de que um autor possa querer inserir em um hiperdocumento os elementos de um site inteiro, como o ilustrado pela Figura 6.5. Esse hiperdocumento possui vários links, e isso faria com que o autor tivesse que visitar cada página. Além disso, teria que renomear manualmente o nome de cada arquivo que estivesse no diretório cache.

Uma solução para esse problema é a utilização de ferramentas que executam a transferência de um site inteiro com um único comando. Durante a fase de testes da ferramenta de importação, os sites, inclusive o ilustrado pela Figura 6.5, foram obtidos utilizando-se a ferramenta WebZip 1.012.

\subsection{2 - Preparaf̧ão do ambiente de importação}

Uma vez tendo o material didático (páginas HTML) armazenado em um diretório local, o autor pode executar a ferramenta de importação e "carregar" o arquivo HTML ptincipal, conforme ilustra a Figura 6.6.

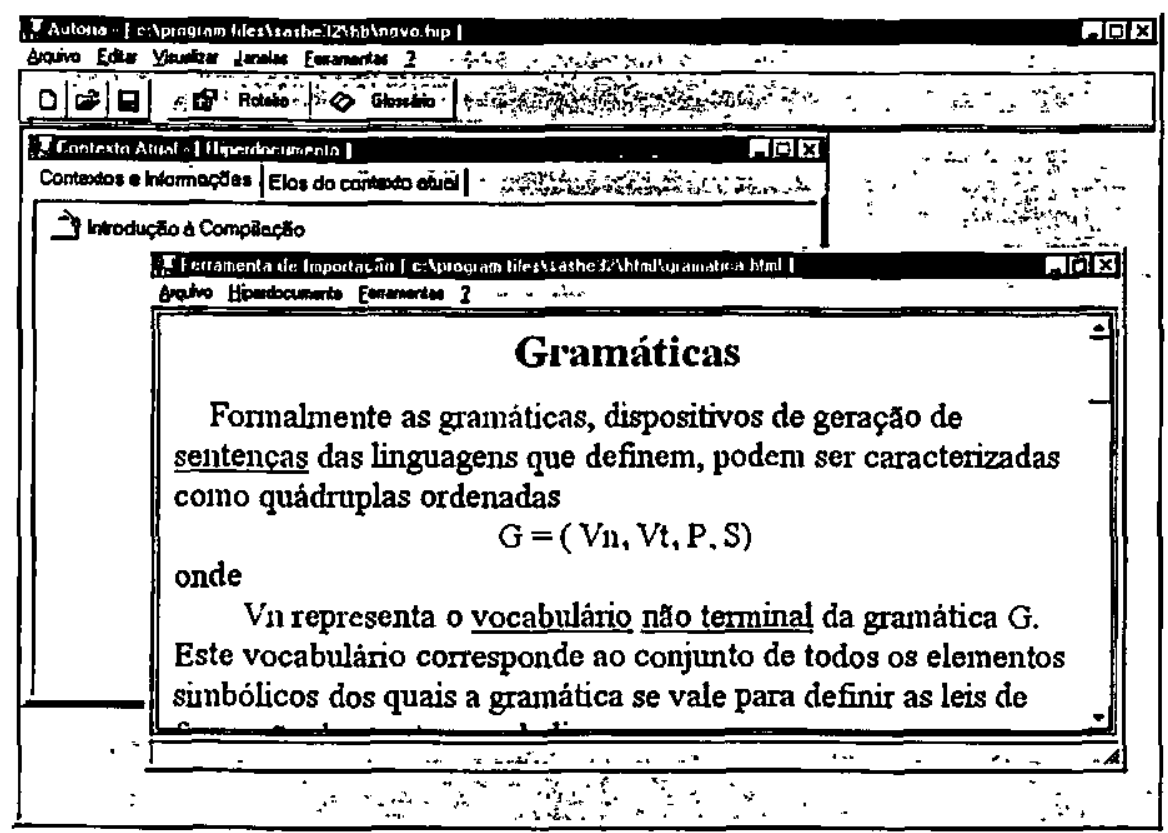

Figura 6.6 - Interface da ferramenta de importação

Nesse momento, uma característica da versão atual do protótipo deve ser apontada: as páginas HTML que possuem estruturação baseada em frames, como a da Figura 6.5, não são processadas 
pelo mecanismo de importação. Todavia, isso não limita o processo de importação de arquivos, pois geralmente, os documentos HTML estruturados em framesets apresentam um arquivo índice. Desse modo, a partir desse arquivo, todos os elementos do hiperdocumento podem passar pelo processo de importação e adaptação e ser inseridos como objetos de um hiperdocumento no SASHE.

No caso do Web-browser, quando o autor estiver navegando por um site que possua etiquetas de estruturação baseadas em frames, as páginas são apresentadas/visualizadas, mas as funcionalidades de importação tornam-se inacessíveis.

\subsection{3 - Definifão das propriedades de importafão}

Conforme apresentado anteriormente, o mecanismo de importação exige que o usuário (autor) estabeleça valores para alguns atributos de importação. Esses atributos vão determinar a estrutura organizacional dos elementos a serem inseridos no hiperdocumento, bem como a sua qualificação, baseada nos atributos previstos pelo SASHE, ou seja, função didática (motivação, introdução, definição, exemplo, exercícios, resumo, bibliografia e ajuda), dificuldade (baixa, regular e alta) e palavras-chave relacionadas ao conteúdo.

Assim, conforme ilustrado pela Figura 6.7, o autor deve primeiramente estabelecer valores para os atributos organizacionais "Profundidade" e "Exibir imagens".

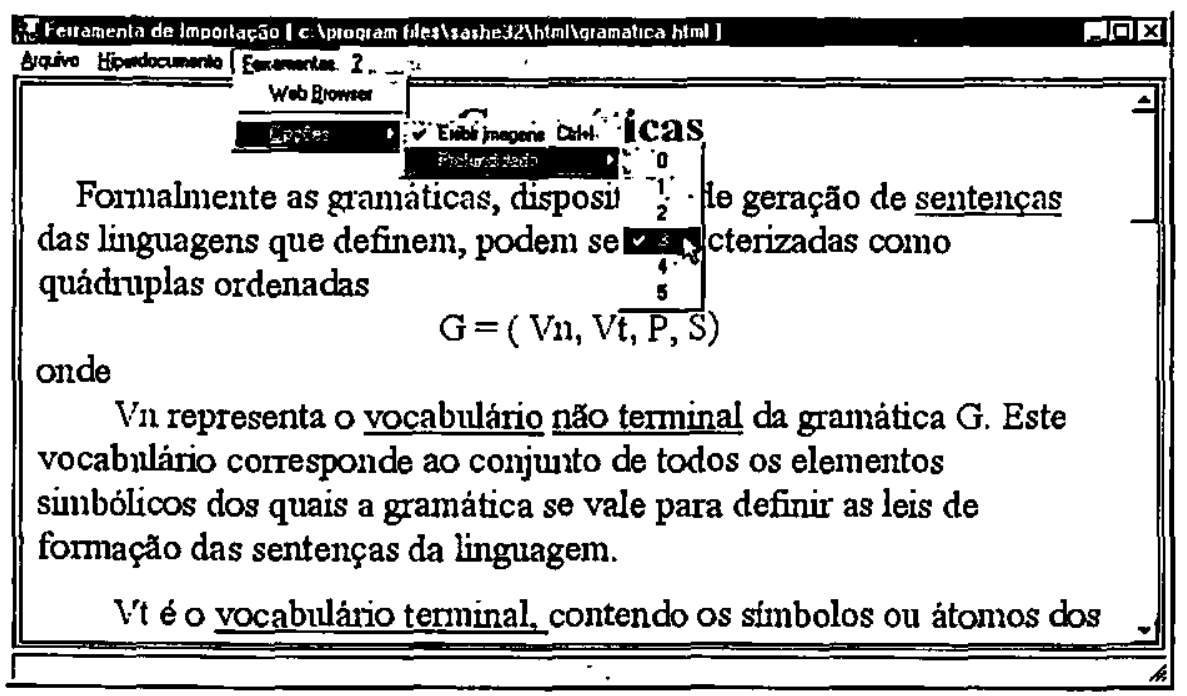

Figura 6.7 - Determinação dos atributos organizacionais "profundidade" e "exibir imagens" 
Nesse caso, o atributo profundidade recebeu o valor 3 e a opção "Exibir imagens" está selecionada. Desse modo, todos os elementos do hiperdocumento (páginas, imagens, âncoras e elos), que estiverem entre os níveis 0 e 3 da hierarquia de relacionamentos do hiperdocumento, serão mapeados para a estrututra organizacional do hiperdocumento sendo editado no SASHE.

Em seguida, o autor pode definir, através da interface ilustrada pela Figura 6.8, as palavras-chave a serem atribuidas para os elementos que vão passar pelo processo de importação e/ou adaptação.

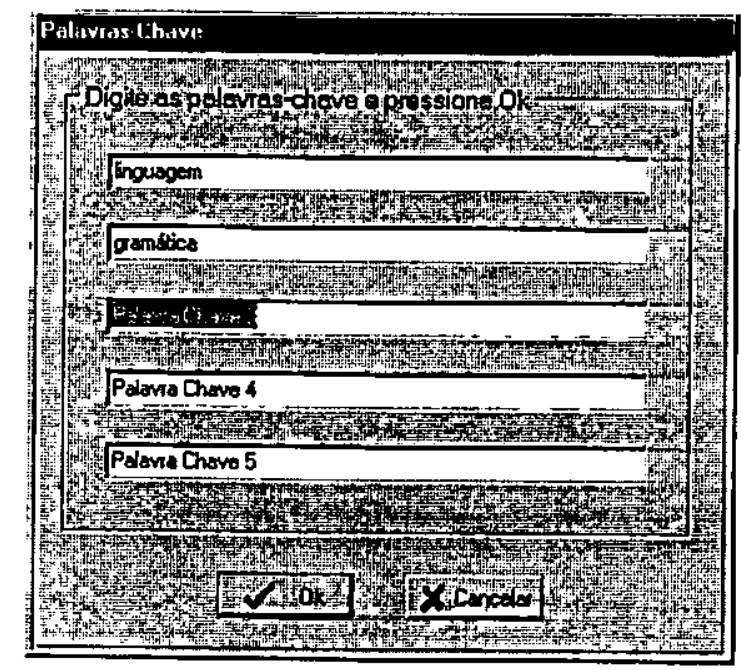

Figura 6.8 - Interface para a definiçāo das palavras-chave

Uma limitação do protótipo atual é atribuir os mesmos atributos e palavras-chave para todos elementos (nós de informação dos tipos texto e imagem) a serem transpostos em uma sessão de importação, pois os ambientes de autoria e navegação do SASHE oferecem para seus usuários, professor (autor) e aprendiz, funcionalidades de seleção de elementos de informação que estejam englobados em um mesmo domínio de conhecimento (assunto), ou que tenham o mesmo grau de dificuldade/facilidade.

Essa busca se baseia nos atributos e palavras-chave de cada elemento. Uma vez que todos os elementos possuem os mesmos atributos e palavras-chave, uma seleção mais criteriosa, ou refinada, pode ficar prejudicada.

Futuramente, pretende-se que, durante um processo de importação, para cada arquivo HTML seja automaticamente definido um conjunto de palavras-chaves referente ao seu conteúdo. A definição de atributos diferenciados para cada elemento pode ser facilmente resolvido, com um simples detalhe de implementação. 


\subsection{4 - Geração do protótipo de biperdocumento}

Após a definição das propriedades "exibir imagens", "profundidade" e "palavras-chave", o usuário (autor) pode iniciar o processo de importação e adaptação do documento HTML sendo visualizado pela ferramenta Html2Hip. Esse comando é realizado através da ativação de um item de menu, conforme ilustrado pela Figura 6.9.

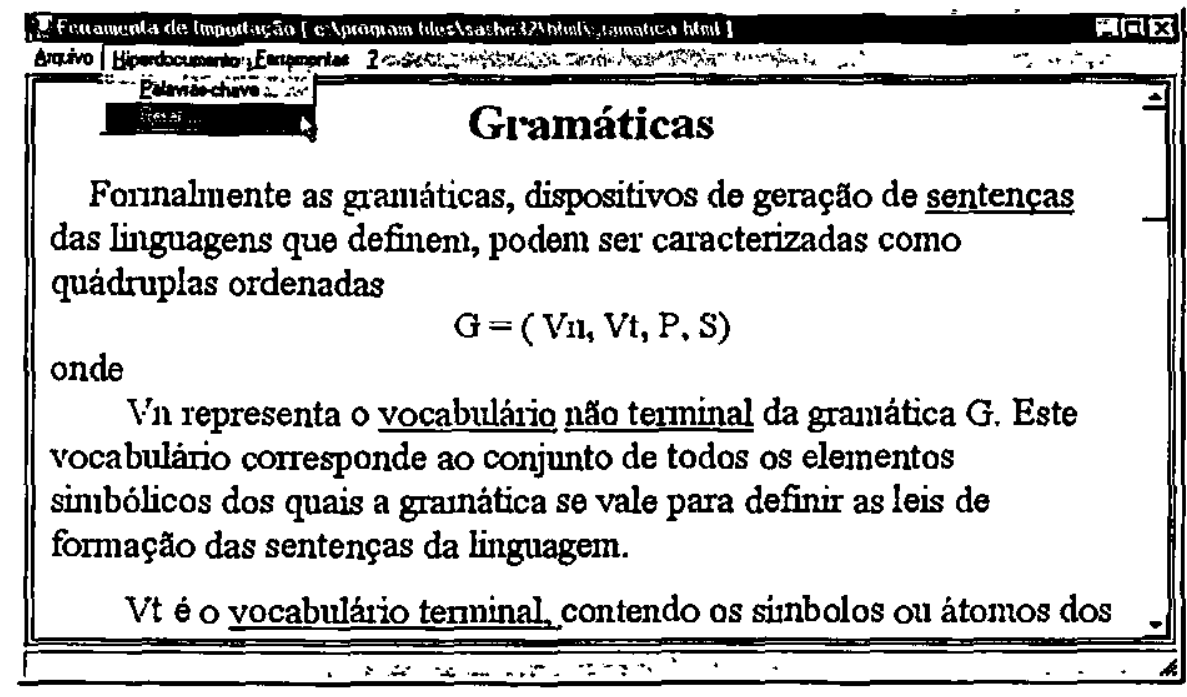

Figura 6.9 - Início do processo de importação

Nesse momento, a ferramenta de importação exibe a janela ilustrada pela Figura 6.10.

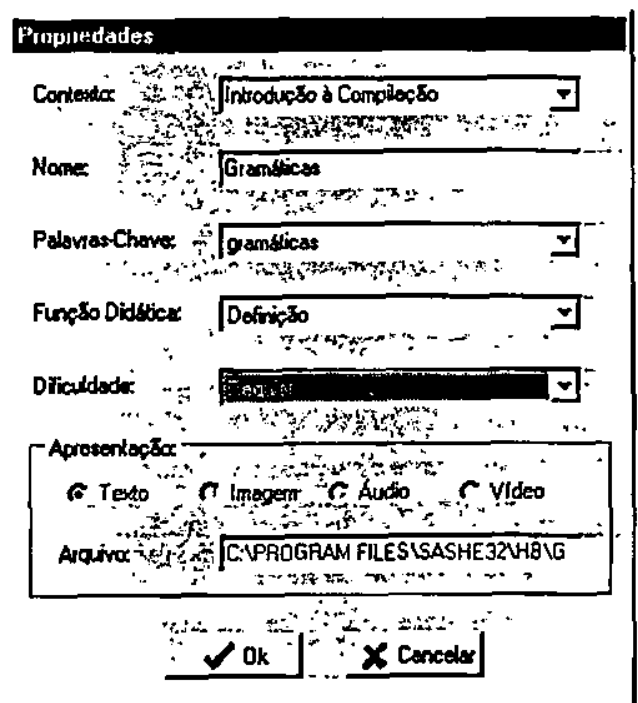

Figura 6.10 - Determinaçāo dos atributos do SASHE 
Agora, o usuário deve definir as propriedades que qualificarão cada elemento a ser inserido no hiperdocumento quanto à sua função didática e dificuldade. Também deve informar o contexto onde as informações serão inseridas. Finalmente, para iniciar a importação, o usuário precisa pressionat o botão "Ok".

\subsection{5 - Avaliação do material obtido}

Após o processo de importação, o autor tem à sua disposição um conjunto de elementos de informação aninhados (agrupados) em um contexto do hiperdocumento sendo editado no ambiente de autoria do SASHE, conforme ilustrado pela Figura 6.11.

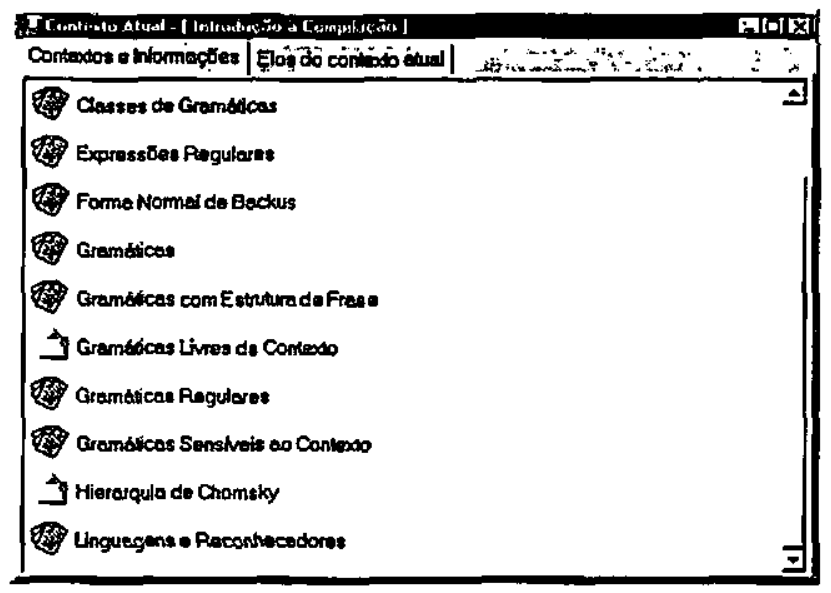

Figura 6.11 - Hiperdocumento obtido com o processo de importação

A organização estrutural dos elementos (nós, elos e âncotas) e a formatação de apresentação do texto (estilos de fonte, alinhamento de parágrafo, posição original das imagens etc.), conforme ilustrado pela Figura 6.12, são mantidas. 


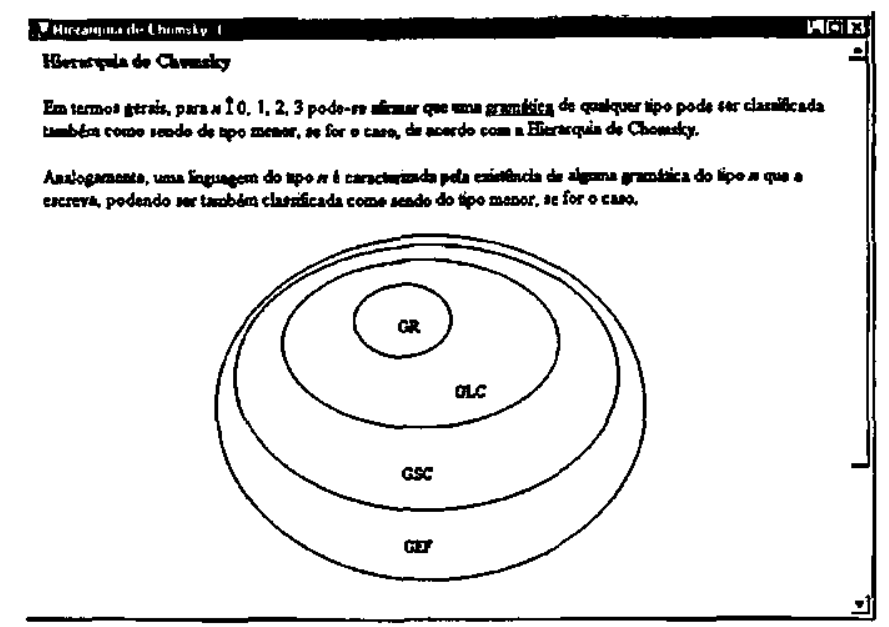

Figura 6.12 - Nó de informaçāo obtido com o processo de importação

Finalmente, o autor pode urilizar as ferramentas do ambiente de autoria para modificar os atributos pertinentes a cada elemento de informação (texto ou imagem), modificar o conteúdo dos nós de informação do tipo texto, definir novas âncoras e elos, bem como adicionar esses novos elementos em um roteiro. Dessa forma, ele poderá avaliar o valor educacional do material importado.

\subsection{6 - Inserção de nós de informação do tippo imagem}

Conforme apresentado anteriormente, a ferramenta de importação processa arquivos HTML e suas respectivas imagens para inserir elementos de informação em hiperdocumentos do SASHE. Também foi visto que se a propriedade "Exibir imagens" não estiver selecionada, apenas são inseridos no hiperdocumento elementos de informação do tipo texto.

Todavia, pode ocorrer que o autor encontre em um site imagens que ilustrem ou exemplifiquem um conceito que ele deseja apresentar em uma atividade tutorial/pedagógica. Porém, o conteúdo textual dessa página não condiz com os objetivos de aprendizado almejados. Nesse caso, tanto o protótipo de ferramenta $\mathrm{Htm} 2 \mathrm{Hip}$, como o Web-browser, permitem que ele importe/adapte apenas as imagens do hiperdocumento.

Para isso, ele precisa carregar a página HTML na ferramenta de importação ou visitar o site com o Web-browser, e estando com a seta do mouse sobre a imagem que ele deseja inserir no hiperdocumento do SASHE, apertar o botão direito do mouse. Nesse caso, conforme ilustrado pela Figura 6.13, é apresentado um menu pop-down, que permite a inserção de tal imagem no hiperdocumento. 


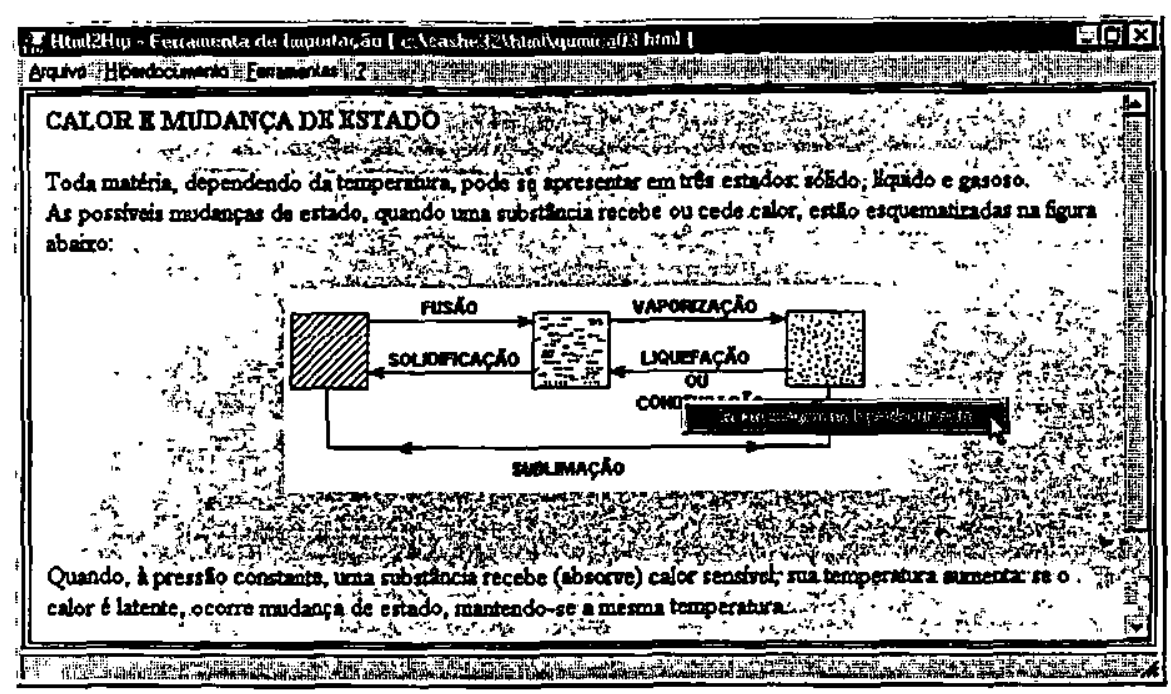

Figura 6.13 - Inserção de imagem em um hiperdocumento SASHE

\section{6 - Considerações finais do capítulo}

A grande maioria dos trabalhos que procuram estabelecer um framework para desenvolvimento, análise e comparação de ambientes computacionais de ensino e aprendizagem defende a necessidade de reutilização de conteúdos já existentes em mídia digital.

Os recursos de importação e adaptação de documentos HTML disponibilizados pela Html2Hip, e integrados ao ambiente de autoria do SASHE, por sua vez, propiciam um ambiente que reconhece a estrutura organizacional de um documento HTML, inserindo elementos de informação em um hiperdocumento sendo editado no SASHE. Dessa forma, tais recursos podem reduzir o tempo de desenvolvimento de um hiperdocumento, reduzindo, também, o investimento (custo) que seria necessário para a elaboração do conteúdo didático.

No próximo e último capítulo, são apresentadas as conclusōes e principais contribuições deste trabalho, bem como os possiveis trabalhos futuros. 


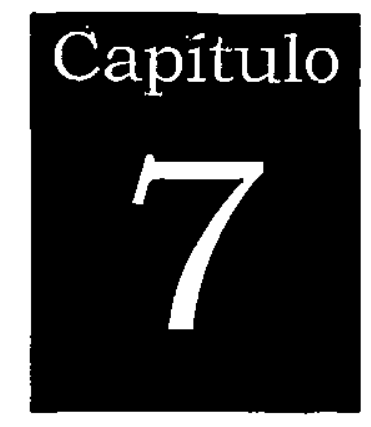

\section{Conclusões}

\section{1 - Considerações iniciais}

O trabalho apresentado nesta dissertação teve como principal objetivo propor um protótipo de ferramenta capaz de reconhecer a estrutura organizacional de um documento HTML (páginas, imagens, âncoras e elos), e mapeá-la para a representação interna do SASHE, que se basein nas abstrações definidas pelo Modelo de Contextos Aninhados.

Além disso, este trabalho estendeu a capacidade do editor de nós de informação do tipo texto do protótipo anterior no que concerne ao processamento de arquivos-texto descritos pelo padrão RTF. Dessa forma, o SASHE tornou-se capaz de processar e organizar materiais instrucionais preparados em seu próprio ambiente, no ambiente WWW, bem como em processadores de texto comuns.

Esta dissertação apresentou: a) uma visão geral da utilização de informática, em especial da tecnologia hipermidia, em ambientes de ensino e aprendizagem; b) alguns ambientes de criação, estruturação e distribuição de material didático na forma de hiperdocumentos; c) os pressupostos técnicos sobre padrões de representação de documentos hipermídia que foram necessátios para a 
definição dos mecanismos de importação e de adaptação de documentos HTML; d) os ambientes de autoria e navegação do protótipo SASHE.

Em seguida, foram apresentadas as principais características e funcionalidades da Html2Hip, o protótipo de ferramenta proposto por esse trabalho, que se encontra integrada ao ambiente de autoria do SASHE. Para finalizar, foi apresentado um exemplo da sua utilização.

\section{2 - Contribuições}

As principais contribuições deste trabalho podem ser assim resumidas:

1. O trabalho propõe um mecanismo de importação e de adaptação de documentos, descritos segundo as propriedades de formatação e estruturação do padrão HTML, para o Modelo de Contextos Aninhados, que fornece as abstrações organizacionais para os elementos de informação (contextos, nós de informação, âncoras e elos) dos hiperdocumentos criados e processados com o auxílio do protótipo SASHE. Esse mecanismo pode ser facilmente estendido para outros padrões (como por exemplo, Latex).

2. Esse mecanismo forneceu as diretrizes para a implementação da $\mathrm{Html2Hip,} \mathrm{um} \mathrm{protótipo} \mathrm{de}$ ferramenta de importação de documentos HTML, que pode facilitar o processo de autoria no SASHE.

3. Outra contribuição foi a modificação da estrutura interna dos nós de informação do tipo texto do SASHE, que antes se baseava em texto plano e sem formatação, e agora manipula documentos descritos segundo o padrão RTF. Essa modificação enriqueceu o feedback visual dos nós de informação do tipo texto processados/apresentados pelos ambientes de autoria $\mathrm{e}$ navegação do SASHE.

\section{3 - Trabalhos futuros}

Alguns dos trabalhos que podem dat continuidade aos resultados apresentados nesta dissertação são:

1. Extensão do parser HTML. Seria interessante que o parser HTML, integrado à ferramenta de importação, passasse a reconhecer todos os elementos de um documento HTML. Nesse caso, tabelas, listas ordenadas, tipos de fonte para caracteres e outros elementos de formatação, bem como framests, marquee e outros elementos estruturais passatiam a ser reconhecidos, 
enriquecendo ainda mais o feedback visual dos documentos criados e processados pelo SASHE. Essa modificação também implicaria na extensão do editor de conteúdo dos nós de informação do tipo texto.

2. Integração do mecanismo de importacão com o ambiente de modelagem do SASHE. Uma vez que a abordagem sistemática proposta pelo método EHDM (Pansanato, 1999) mostrou-se útil para apoiar o projeto de aplicações hipermidia para ensino, seria interessante a integração do ambiente de modelagem do SASHE com as funções de conversão e adaptação utilizadas pelo mecanismo de importação. Essa integração possibilitaria o desenvolvimento de um ambiente de autoria para Web-sites modelados segundo as abstraçōes organizacionais e estruturais defendidas pelo método.

3. Enriquecimento da interação com o aprendiz. O componente Delphi, que na versão atual do SASHE trata de apresentar o conteúdo de um nó de informação do tipo texto, é capaz de reconhecer e processar trechos de código JavaScript. Dessa forma, seria interessante a definição de uma nova função didática (como por exemplo, simulação) para os elementos de informação dos hiperdocumentos do SASHE. Essa estratégia implica: a) na definição e implementação de uma ferramenta que ofereça suporte automatizado ao desenvolvimento de códigos Java Script, tal como as ferramentas propostas por Santos (1998) e Castro (1997); e b) na extensão do mecanismo de importação para que ele passe a reconhecer etiquetas de inserção de código JavaScript.

Por outro lado, o protótipo do SASHE apresentado por Santos (1997), foi complexo e interessante o suficiente para deixar uma série de trabalhos subseqüentes a serem feitos, citados a seguir:

1. Avaliação da proposta do ponto de vista do autor. Como o SASHE prevê dois tipos de usuários, o autor do hiperdocumento e o aprendiz, são necessárias avaliações sob esses diferentes pontos de vista. No caso do autor, cabe verificar, experimentalmente, as facilidades oferecidas pelo sistema para a construção de hiperdocumentos e roteiros para aplicações no ensino.

2. Avaliação da proposta do ponto de vista do aprendiz. Analogamente ao caso anterior, a utilização do ambiente por grupos de usuários devidamente qualificados para a experiência deverá apontar fatores de eficácia do sistema (como por exemplo, se a utilização do sistema provocou uma melhoria no desempenho do aprendiz). 
3. Generalização para outros domínios de aplicação. Não só usuários de aplicativos educativos podem se beneficiar dos recursos propostos no SASHE. Outras aplicaçōes podem tirar proveito da possibilidade de se criar roteiros com diferentes graus de liberdade, bem como de se definir estratégias de busca de nós alternativos. Dessa forma, o autor poderia determinar os atributos de nós pertinentes ao domínio de aplicação, os botões e correspondentes funçōes associadas, que deveriam compor a interface com o aprendiz, bem como definir possíveis estratégias de busca de informações alternativas.

Atualmente, um trabalho de mestrado está propondo a generalização do SASHE para a Engenharia de Software. Para isso, serão definitos: a) novos atributos de qualificação para os nós; b) novos botōes de interação no ambiente de navegação; e c) uma modificação na interface dos ambientes de autoria e navegação.

4. Estender o SASHE para um ambiente distribuído. A proposta HyperProp (Soares et al., 1995b) prevê a implementação do Modelo dos Contextos Aninhados de forma distribuída, onde aparecem os conceitos de hiperbase pública (no servidor) e hiperbases privadas (nos clientes). Atualmente, o SASHE trata apenas hiperbases privadas (hiperdocumentos), e estende-lo nesse sentido também é objetivo de curto ou médio prazo. Um protótipo de ferramenta, que implementa a distribuição de hiperdocumentos (ou hiperbases) estruturados de acordo com as abstraçōes definidas pelo MCA, pode ser encontrado em (Rodrigues \& Soares, 1998).

\section{4 - Considerações finais}

De modo geral, o desenvolvimento de pesquisas que investigam a aplicação da informática na Educação tem ganhado cada vez mais espaço na comunidade científica de Ciência da Computação. Nesse contexto, é válido ressaltar que se tem observado o crescimento da utilização de sistemas computacionais em ambientes de ensino e aprendizagem, principalmente com o advento da Internet e, especialmente, com a disseminação do ambiente WWW.

Assim sendo, o desenvolvimento de ferramentas/mecanismos que propiciem a reutilizaçäo e/ou adaptação de conteúdos didáticos disponibilizados nesse ambiente para o ambiente de autoria do SASHE torna-se relevante, uma vez que o ambiente WWW é caracterizado, basicamente, pela publicação de hiperdocumentos simples, construídos segundo as regras do padrão HTML, que não permite agrupamento hierárquico e qualificação dos objetos de seus hiperdocumentos. 
Dessa maneira, o protótipo de ferramenta de importação proposto por este trabalho, a Html2Hip, mostrou-se útil para apoiar a construção de hiperdocumentos no SASHE, reduzindo o tempo e custo de desenvolvimento neste sistema. 


\section{Referências Bibliográficas}

(AulaNet, 1998) Projeto AulaNet, 1998.

On-Line: http://aulanet.les.inf.puc-rio.br/aulanet/misc/aulanet.pdf [ 6/1/1999]

(Barker \& Manji, 1992) Barker, R.M.; Manji, K, "Computer-based Training: An institutional approach", Education \& Computing, n.8, pp.229-237, 1992.

(Berners-Lee et al., 1994) Berners-Lee, T.; Cailliau, R.; Luotonen, A.; Nielsen, H.F.; Secret, A., "The WorldWide Web", Communications of $A C M$, vol.37, n.8, pp.76-82, 1994.

(Bieber \& Vitali, 1997) Bieber, M.; Vitali, F., "Toward Support for Hypermedia on World-Wide Web", IEEE Computer, pp.62-70, 1997.

(Bordenave \& Pereira, 1988) Bordenave, J.D.; Pereira, A.M., Estratégias de Ensino-Aprendizagem, 10an Edição, Editora Vozes, 1988.

(Brown, 1989) Brown, H., "Standards for Structured Documents", The Computer Joumal, n.6, vol.32, pp.505514, 1989.

(Brusilovsky et al., 1996) Brusilovsky, P.; Schwarz, E.; Weber, G., “A tool for developing adaptive electronic textbooks on WWW", In: WebNet'96 (World Conference of the Web Society) Proceedings, pp.64-69, 1996.

On-Line: http://www.contrib.andrew.cmu.edu/ plb/WebNet $96 . h t m l$ [ 5/2/1998] 
(Brusilovsky, 1990) Brusilovsky, P., "Methods and Techniques of Adaptive Hypermedia", User Modeling and User-Adapted Interaction, 6(2-3), pp. 87-129, 1996.

(Buford, 1994) Buford, J.F.K, "Uses of multimedia information", Multimedia Systems, Addison-Weslley, pp.125, 1994.

(Campbell et al, 1995) Campbell, J.K; Hurley, S.; Jones, S.B.; Stephens, N.M., "Constructing educational courseware using NCSA Mosaic and the World-Wide Web", In: Third International World-Wide Web Conference Proceedings, Darmstadt, Germany, 1995.

On-Line: http://www.igd.fhg.de/www/www95/proceedings/papers/52/www3.html [8/2/1999]

(Casanova et al., 1991) Casanova, M.A.; Tucherman, L.; Lima, M.J.; Rangel, J.L.; Rodriguez, N.L.R.; Soares, L.F.G., "The Nested Context Model for Hyperdocuments", In: Third ACM Conference on Hypertext Proceedings, pp.193-201, 1991.

(Castro et al., 1997) Castro, M.A.S.; Goularte, R.; Reami, E.R.; Moreira, E.S., "Infra-Estrutura de Suporte à Editoração de Material Didático Utilizando Multimídia", Revista Brasileira de Informática na Educasaão, n.01, pp.61-70, 1997.

(Castro, 1997) Castro, M.A.S., Projeto de um Sistema de Auxilio à Preparafão de Material Didático para uso na WorldWide Web, Dissertação de Mestrado, ICMC-USP, 1997.

(Conklin, 1987) Conklin, J.A., "Hypertext. An Introduction and Survey", IEEE Computer, v.10, n.9, pp.17-40, 1987.

(Costa e Xexéo, 1996) Costa, R.M.E.M.; Xexéo, G.B., "A Internet nas escolas: uma proposta de ação", In: VII Simpósio Brasileiro de Informática na Educação Anais, pp.105-118, 1996.

(Crespo et al., 1998) Crespo, S.; Fontoura, M.F.M.C.; Lucena, C.J.P., "Um Modelo Conceitual Compativel com a Plataforma EDUCOM/IMS para Comparação de Ambientes de Educação na WEB", In: Simpósio Brasileiro de Informática na Educação (SBIE'98) Anais, 1998.

(Danielson, 1997) Danielson, L.D., "Learning Styles, Media Preferences and Adaptive Education", In: Workshop of Adaptive Systems and User Modeling on the World-Wide Web Proceedings, Sixth International Conference on User Modeling, 1997.

(Dias \& Sousa, 1997) Dias, P.; Sousa, A.P., "Understanding Navigation and Disorientation in Hypermedia Learning Environments", Journal of Educational Multimedia and Hypermedia, 6(2), pp.173-185, 1997.

(Duncan, 1989) Ducan, E.B., “A faceted approach to hypertext?", Hypertext: Theory into practice, Norwood, N.J:: Ablex Publishing Corporation, pp.157-163, 1989.

(Dunlop, 1998) Dunlop, A., "What online businesses are overlooking", Internet World Daiby, 1998.

On-Line: http://www.iw.com/daily/news/1998/01/2701-online.html [28/1/1997] 
(Eklund et al., 1997) Eklund, J.; Brusilovsky, P.; Schwarz, E., "Adaptive Textbooks on the Word Wide Web", In: The Second Australian World-Wide Web Conference Proceedings, 1997.

On-Line: http://ausweb.scu.edu.au/proceedings/eklund/paper.html [5/2/1998]

(Eklund, 1995) Eklund, J., "Cognitive Models for Structuring Hypermedia and Applications for Learning from World-Wide Web", In: The First Australian World-Wide Web Conference Proceedings, 1995.

(Freitag \& Sullivan, 1995) Freitag, E.T.; Sullivan, H., "Matching the Leamer Preference to Amount of Instruction: An Alternative Form of Learner Control", Educational Technology Research and Development, 43(2), pp.5-14, 1995.

(Garzotto et al., 1993) Garzotto, F.; Paolini, P.; Schwabe, D., "HDM - A Model-Based Approach to Hypertext Application Design", ACM Transactions on Information Systems, v.11, n.1, pp.1-26, 1993.

(Gibson et al., 1996) Gibson, E.J.; Brewer, P.W.; Dholakia, A.; Vouk, M.A.; Bitzer, D.L., "A Comparative Analysis of Web-Based Testing and Evaluation Systems", 1996.

On-Line: http://renoir,csc.ncsu.edu/MRA/Reports/WebBasedTesting.html [5/2/1999]

f(Ginige et al., 1995) Ginige, A.; Lowe, D.; Robertson, J., "Hypermedia Authoring", IEEE Multimedia, pp.24 35, 1995.

(Goldberg et al., 1996) Goldeberg, M.W.; Salari, S.; Swoboda, P., "World-Wide Web - Course Tool: An Environment for Building WWW-Based Courses", In: Fifth International World Wide Web Conference, France, 1996.

On-Line: http://homebrew.cs.ubc.ca/webct/papers/p29/index.htmi [ 5/2/1999]

(Goodyear et al., 1991) Goodyear, P.; Njoo, M.; Hijine, H.; Berkum, J.J.A., “Learning processes, learner attributes and simulations", Education \& Computing, n.6, pp.263-304, 1991.

(Hardin \& Ziebarth, 1995) Hardin, J.; Ziebarth, J., "Digital Technology and its Impact on Education", In: The Future of Networking Technologies for Learning Proceedings, 1995.

On-Line: http://inet.ed.gov/Technology/Futures [6/2/1999]

(Herwijnen, 1994) Herwijnen, E., Practical SGML, Kluwer Academic Publishers, Massachusetts, Second Edition, 1994.

(Isakowitz et al., 1995) Isakowitz, T.; Stohr, E.A.; Balasubramanian, P., "RMM: A Methodology for Structured Hypermedia Design”, Communications of the ACM, v.38, n.8, pp.34-44, 1995.

(Jacobson et al., 1996) Jacobson, M.J.; Maouri, C.; Mishra, P.; Kolar, C., "Learning With Hypertext Environments: Theory, Design, and Research", Joumal of Educational Multimedia and Hypermedia, 5(3/4), pp.239-281, 1996.

Jong, 1991) Jong, T., "Learning and instruction with computer simulations", Education \&o Computing, n.6, pp.217-229, 1991. 
(Large, 1996) Large, A., "Hypertext instructional programs and learner control: a research review”, Education for Information, n.14, pp.95-107, 1996.

(Lucena et al., 1997) Lucena, C.; Fuks, H.; Milidiú, R.; Macedo, L.; Santos, N.; Laufer, C.; Fontoura, M.; Neves, P.; Crespo, S.; Cardia, E.; Torres, V., "AulaNet: Um Ambiente para Desenvolvimento e Manutenção de Cursos na WWW", Monografias em Ciência da Computação, Departamento de Informática, PUC-Rio, 1997.

(Menezes et al., 1998) Menezes, R.A.; Fuks, H.; Garcia, A.C.B., "Utilizando Agentes no Suporte à Avaliação Informal no Ambiente de Instrução Baseada na Web - AulaNet", In: Simpósio Brasileiro de Informática na Educação (SBIE’98) Anais, 1998.

(Moreira et al, 1995) Moreira, E.S.; Nunes, M.G.V.; Pimentel, M.G.C., "Design Issues for a Distributed Hypermedia Tutoring System (HyDTS)", In: International Conference on Computer Applications in Industry Proceedings, Cairo, 1995.

(Nielsen, 1990) Nielsen, J., Hypertext \& Hypermedia, Academic Press Inc., pp.1-14, 1990.

(Uunes \& Fortes, 1997) Nunes, M.G.V.; Fortes, R.P.M., "Roteiros em Aplicações de Ensino: a Questão do Controle do Leitor", In: III Workshop em Sistemas Multimídia e Hipermídia Anais, São Carlos, pp.15-27, 1997.

(Nunes \& Santos, 1998) Nunes, M.G.V.; Santos, G.H.R., "SASHE: autoria de aplicações hipermídia para ensino", In: III Simpósio de Teses e Dissertações Anais, Departamento de Ciência da Computação e Estatística, ICMC-USP, São Carlos, pp.127-139, 1998.

(Nunes et al., 1996) Nunes, M.G.V.; Vieira, F.M.C.; Hasegawa, R., "Hip/Windows: Um Ambiente de Autoria de Hiperbases Multimídia", Relatórios Técricos do ICMSC, ICMSC-USP, n.38, 1996.

(Nunes et al., 1997) Nunes, M.G.V.; Hasegawa, R.; Vieira, F.M.C.; Santos, G.H.R; Fortes, R.P.M., “SASHE: Sistema de Autoria e Suporte Hipermidia para Ensino", Notas Didáticas do ICMC, ICMC-USP, n.33, 1997.

(Nwana, 1990) Nwana, H.S., "Intelligent Tutoring Systems: an overview", Antificial Intelligence Review, n.4, pp.251-277, 1990.

(Pansanato, 1999) Pansanato, L.T.E., EHDM: Un Método para o Projeto de Aplicafões Hipermidia para Ensino, Dissertação (Mestrado) submetida à Comissão de Pós-Graduação - Instituto de Ciências Matemáticas e de Computação, Universidade de São Paulo, 1999.

(Pimentel \& Hagui, 1996) Pimentel, M.G.C.; Hagui, S.H., "Usando a WWW como ferramenta de apoio ao ensino”, In: VII Simpósio Brasileiro de Informática na Educação Anais, pp.55-68, 1996.

'(Pimentel et al., 1998) Pimentel, M.G.C.; Santos, J.B.J.; Fortes, R.P.M., "Modelagem, autoria e apresentação de documentos didáticos estruturados", In: IV Simpósio Brasileiro de Sistemas Multimídia e Hipermídia, Rio de Janeiro, 1998. 
(Preece et al., 1994) Preece, J.; Rogers, Y.; Sharp, H.; Benyon, D.; Holand, S.; Carey, T., Human-Computer Interaction, Addison-Wesley Publishing Company, 1994.

(Rodrigues \& Soares, 1998) Rodrigues, R.F.; Soares, L.F.G., "Integração dos Sistemas HyperProp e WWW", In: IV Simpósio Brasileiro de Sistemas Multimídia e Hipermidia Anais, Pp.175-186, Rio de Janeiro, 1998.

(Romiszowsky, 1997) Romiszowsky, A.J., "Web-Based Distance Learning and Teaching: Revolutionary Invention or Reaction to Necessity?", Web-based instruction, Educational Technology Puhlications, New Jersey, pp.25-37, 1997.

(Rossi, 1996) Rossi, G., Um Método Orientado a Objetos para o Projeto de Aplicajóes Hipermídia, Dissertação de Doutorado - Departamento de Informática, Pontificia Universidade Católica do Rio de Janeiro, 1996.

(Russel \& Novig, 1995) Russel, S.J.; Novig, P., Artificial Intelligence - A Modern Approach, Ptentice-Hall Intemational Inc., pp.55-56, 1995.

(Santos et al., 1997) Santos, G.H.R; Vieira, F.M.C.; Hasegawa, R; Nunes, M.G.V., "SASHE: Autoria de Aplicações Hipermídia para o Ensino", In: VIII Simpósio Brasileiro de Informática na Educação Anais, pp.425-440, 1997.

(Santos, 1997) Santos, G.H.R, Sistemas Hipermidia para o Ensino: Estendendo as Facilidades para o Tutor e 0 Estudante, Dissertação de Mestrado, ICMSC-USP, 1997.

(Santos, 1998) Santos, J.B., Documentos Estruturados para o Dominio de Aplicagão Ensino: Modelagem, Autoria e Apresentafão na WIWW, Dissertação de Mestrado, ICMC-USP, 1998.

(Schank, 1994) Schank, R., “Active Learning through Multimedia”, IEEE Multimedia, 1(1), pp.69-78, 1994.

(Schwabe et al., 1996) Schwabe, D.; Rossi, G.; Barbosa, S.D.J., "Systematic Hypermedia Application Design with OOHDM", In: Hypertext96 Proceedings, Washington, pp.116-128, 1996.

(Schwarz et al., 1996) Schwarz, E.; Brusilovsky, P.; Weber, G., "World-Wide Web intelligent textbooks", In: Wotld Conference on Educational Telecommunications Proceedings, pp.302-307, Boston, 1996.

On-Line: http://www.informatik.uni-trier,de/ schwatz/ED-MEDIA-96.htm] [ 5/2/1998]

(Soares et al., 1994) Soares, L.F.G.; Rodriguez, N.L.R.; Casanova, M.A., "Modelo de Contextos Aninhados: Um Modelo Conceitual Hipermidia”, Revista Brasileira de Computafão, v.7, n.2, pp.35-48, 1994.

(Soares et al., 1995a) Soares, L.F.G.; Rodriguez, N.L.R, Casanova, M.A., "NCM: A Conceptual Model for Hyperdocuments", İn: I Workshop em Sistemas Hipernidia Distribuidos Anais, pp.40-46, São
Carlos, 1995. (Soares et al., 1995b) Soares, L.F.G. et al., "HyperProp: Uma Visão Geral", In: I Workshop em Sistemas
Hipermídia Distribuídos Anais, pp.1-12, São Catlos, 1995. 
(Tapscott, 1997) Tapscott, D., Growing Up Digital: The Rise of the Net Generation, McGraw-Hill, 1997.

(Tsybenko \& Bykov, 1997) Tsybenko, Y.; Bykov, V., "Feedback and Adaptive Interaction for WWW-based Courses", In: Workshop of Adaptive Systems and User Modeling on the World-Wide Web Proceedings, Sixth International Conference on User Modeling, 1997.

On-Line: http://www.contrib.andrew.cmu.edu/ plb/UM97 workshop/Tsybenko.html [ 5/2/1999]

(Valente, 1993) Valente, J.A., Computadores e conbecimento: repensando a educaf̧āo, Gráfica Central da UNICAMP, Campinas, 1993. 


\section{Bibliografia consultada}

CANTÙ, M., Dominando o Delphi 3 - "A Biblia", Makron Books do Brasil, 1997.

CANTÙ, M; GOOCH, T.; LAM, J.F., Delphi Developer's Handbook, Sybex, 1998.

DONOVAN, T., Industrial-Strength: SGML - An Introduction to Enterprise Publishing, Prentice Hall PTR, 1997.

HORTON, W., Designing and Writing Online Documentation: Hypermedia for Self-Supporting Products, John Wiley \& Sons, Second Edition, 1994.

KOMMERS, P.; FERREIRA, A.; KWAK, A., Document Management for Hypermedia Design, Springer, 1998.

LANGSAM, Y.; AUGENSTEIN, MJ.; TENENBAUM, A., Data Structures Using C and C++, Second Edition, Prentice Hall, 1996.

MICROSOFT, Rich Text Format Specification, RTF Version 1.4, Application Note, 1995.

On-Line: http://www.sunpack.com/RTF/RTF114.htm [5/10/1998]

W3C, HyperText Markup Language (HTML) 4.0 - World-Wide Web Consortium Recommendation, 1998. On-Line: http://www.w3,otg/TR/1998/REC-html40-19980424 [5/7/1998 ] 